\title{
DESENVOLVIMENTO DE TRÊS PORTA-ENXERTOS CÍTRICOS UTILIZANDO ÁGUAS SALINAS
}

\section{TALES MILER SOARES}

Engenheiro Agrônomo

Orientador: Prof. Dr. SERGIO NASCIMENTO DUARTE

Dissertação apresentada à Escola Superior de Agricultura "Luiz de Queiroz", Universidade de São Paulo, para obtenção do título de Mestre em Agronomia, Área de Concentração: Irrigação e Drenagem.

P I R A C I C A B A

Estado de São Paulo - Brasil

Dezembro - 2003 


\section{ERRATA}

TALES MILER SOARES. Desenvolvimento de três porta-enxertos cítricos utilizando águas salinas.

\begin{tabular}{|c|c|c|}
\hline p. & Onde se lê & Leia-se \\
\hline $\begin{array}{c}\text { viii, xi, xvi, } 16,37,38,41 \\
42,43,46,59,89,90\end{array}$ & taxa de lixiviação & fração de lixiviação \\
\hline xvi, $3,10,20,38$ & cloro & cloreto \\
\hline $8,17,20,48,56,67$ & Ayers e Westcot (1999) & Ayers e Westcot (1991) \\
\hline 13 & Tavieira & Taveira ${ }^{\circ}$ \\
\hline 66 & $\mathrm{~L}^{3}$ & $\mathrm{~L}$ \\
\hline 67 & absorção & adsorção \\
\hline \multirow[t]{3}{*}{67} & \multirow{2}{*}{$\mathrm{RAS}=\sqrt{\frac{\mathrm{Na}}{(\mathrm{Ca}+\mathrm{Mg})}}$} & $\mathrm{Na}$ \\
\hline & & $(\mathrm{Ca}+\mathrm{Mg})$ \\
\hline & $\sqrt{2}$ & $\sqrt{2}$ \\
\hline 67 & 48,55 e 75,72 & 45,40 e 57,51 \\
\hline 67 & 3,56 e 7,12 & 3,33 e 5,41 \\
\hline 68 & $1,21 \mathrm{dS} \mathrm{m}^{-1}$ & $1,19 \mathrm{dS} \mathrm{m}^{-1}$ \\
\hline 68 & $17 \%$ & $20 \%$ \\
\hline 92 & 0.192 & 0.8260 \\
\hline 92 & $\mathrm{vgCa}$ & $\mathrm{Ca}$ \\
\hline 93 & 0.356 & 0.7013 \\
\hline 93 & 0.397 & 0.8101 \\
\hline
\end{tabular}




\section{Soares, Tales Miler}

Desenvolvimento de ffês porta-enxertos cítricos utilizando águas salinas / Tales Miler Soares. - - Piracicaba, 2003.

94 p. : il.

Dissertação (mestrado) - - Escola Superior de Agricultura Luiz de Queiroz, 2004. Bibliografia.

1. Água salina 2. Cálcio 3. Crescimento vegetal 4. Fruta cítrica 5. Irrigação 6. Mudas 7. Porta-enxertos 8. Química do solo I. Título

CDD 634.3

Permitida a copia total ou parcial deste documento, desde que citada a fonte - 0 autor? 
Seu nome era Ventor e para ele também o tempo contribuía com anos de vida. Um menininho tão promissor e de saúde tão abalada. Podia brincar de bola, mas quase sempre estava de cama. Em 1981, estava ele um organismo esquálido, tomado por uma infecção hospitalar generalizada fomentada por uma misteriosa alergia. Explicaram para Monna que muitas coisas poderiam the fazer mal. Peixe, camarão, abacaxi, poeira, ácaros, seda, fumaça, sol, pêlos, carambola... emoção. Um menino, outrora apenas com alergia ao mundo e todas as substâncias ao seu redor, então espalhado nos higiênicos lençóis brancos da Santa Casa de Misericórdia, sem compreender porquê a sua pele, encravada por placas sanguinolentas, ardia... porquê seus olhos estavam inchados até às maçãs do rosto... e suas mãos trêmulas transpirando adstringentes... Vendo Monna chorar sua gravidade ao fiscalizar seu soro, era incapaz de melhorar a sonoridade repulsiva de sua respiração, e também não entendia porque sua boca não conseguia falar letras do alfabeto. Quando seu peito disparou à sua frente, deixando-o para trás na impotência, seus olhos inchados apenas janelaram as últimas lágrimas de Monna. Então morreu ... Mas aquela criança, que nunca vira mãe chorar, tomou-se por tanta culpa... que precisou ressuscitar para solicitá-la: 'Não chora, não, mãe! Não chora, não. 'Milagre maior que a ressurreição do anjo de maçãs arroxeadas foi o estancamento das lágrimas de uma mãe desobediente, enquanto um morto-vivo desconjuntado, forçando-se a respirar melhor para amenizar o sofrimento que causava a ela, ponderou que só continuava vivendo por ela. Fingindo sua cura para mitigar Monna, ele fora precocemente levado para casa, onde todo meio-dia tomaria banho com um remédio de cheiro sulfurado misturado à água quente. Os calafrios pareciam afugentar as manchas de sangue da pele esverdeada pela alergia, $e$ pouco a pouco Ventor tinha seu corpo desinchado, seus olhos reabriam. Mas sua cura também vinha de maneira drástica, mediante total cobertura do corpo por milhares de pontuações de pus. Os lençóis de sua casa pareciam não tão higiênicos quanto os do hospital, talvez fossem menos numerosos. O fato é que Ventor liqüefazia-se em pus em tudo que tocava e encostava.. E o pus tinha o cheiro do remédio dos banhos quentes. Não podia vestir camisa. Não podia vestir calças. Não podia usar meias. Tudo no pus colava. Não podia escovar o cabelo. Até suas gengivas, pontuadas, impediam-no de escovar os dentes. Até o esôfago... trincava-se com o pus. E somente para não preocupar Monna, criava-se o menino, martirizando-se a cada copo de água, a cada garfada de comida amassada. Chacoalhado, parecia que seu organismo era só ossos e carne emulsionada em pus fétido. As moseás cercavam a presença de Ventor que, quarentenado no próprio lar, desvendava ser aquelè o preço da volta. E, estranhamente, sua vida não mais demandava tantas experiências promissoras. A vida, apenas um favor a uma pessoa admirável. Sua vida... seu favor. Seu nome foi Ventor... e ele faria tudo para não ver Monna chorar. Seu nome foi Ventor... Existem pessoas que vivem, elas são as que buscam a profusão. Existem pessoas que subvivem, elas são as que tentam. A partir de 1981, passou a existir uma pessoa que apenas... ocorria. Ainda chamam-no de Ventor. E ele ocorre. E, vez ou outra, quando corre e sua, exala ainda o odor combinado do remédio com o pus, lembrando-se da residualidade daquilo que seria sua existência primeira. Sua vida não mais tinha sentido porque nem era para ele estar em vida. Alguns poderiam pensar que a ressurreição deve vir com o agradecimento e a intensidade, mas ele só voltara para fazer sua Monna quietar. Só um favor. Só sua vida... E ninguém nunca soube porque era ele tão sóbrio. Mas a Natureza lhe reservava um outro destino ético. E por mais pacífica que fosse sua 'ocorrência', ele sempre seria incitado a lutar, contra o mesmo mundo dos agentes alergênicos. E sempre seria imolado a nunca alcançar sua alforria. Forte cresceria, criancinha angélica de maçãs coradas, porém, sob a eterna divida do regime do Carbono \& Enxofre. (Adaptado de "Enfim um nome para o soldado desconhecido") 
Aos mantenedores do antropocentrismo $\mathrm{E}$ às insubstituíveis crianças dos anos 80 , CONSIGNO 


\section{AGRADECIMENTOS}

Ao professor Sergio Nascimento Duarte pela orientação, boa vontade, sobriedade e exemplo de lucubração;

Aos colegas e amigos do curso de pós-graduação em Irrigação e Drenagem, pelo convívio e por respeitarem a natureza de um ser recalcitrante;

Ao Departamento de Engenharia Rural da Escola Superior de Agricultura "Luiz de Queiroz", pela confiança;

Aos professores Tarlei Arriel Botrel, José Antônio Frizzone, Rubens Duarte Coelho, Marcos Vinicius Folegatti, Iran José Oliveira da Silva e Décio Eugênio Cruciani, pelos ensinamentos;

Ao professor Silvio Sandoval Zocchi, pela atenção e boa vontade no planejamento e execução da análise estatística;

Aos funcionários, do Departamento de Engenharia Rural, Davilmar, Sandra, Gilmar, Hélio, César, Osvaldo e Antônio, pelas facilidades e presença;

Ao empresário Christiano César Dibbern Graf pela confiança, boa vontade, entusiasmo e espírito crítico;

Aos companheiros da CITROGRAF MUDAS pela amizade, boa vontade e pelo convívio salutar;

Aos professores da Escola de Agronomia da Universidade Federal da Bahia (UFBA), em especial ao professor Francisco Adriano de Carvalho Pereira, pelos ensinamentos e indicação ao curso de mestrado na ESALQ-USP; 
Aos membros da banca de Qualificação, Rubens Duarte Coelho, Francisco Mourão Filho e Ênio Farias de França e Silva, pelas sugestões, críticas, fomento e demonstração da necessidade de se atentar para todas as sub-temáticas tratadas;

Ao pesquisador Paulo Ernesto Meissner Filho, da Embrapa Mandioca e Fruticultura, primeiro orientador;

Aos companheiros da CIBRAFÉRTIL, em especial a Alexandre Pinheiro Fernandes, Marcus Prates, Juarez e César, por terem facilitado minha ausência da empresa quando da decisão pela pós-graduação;

Aos promissores engenheiros Eliezer Gervásio, Vinícius Costa, Eduardo Girardi, Marcelo Zannetti, Nildo da Silva Dias, José Alves Júnior, Tonny Silva e Cláudio Ricardo, pelas discussões sugestivas, dúvidas esclarecidas e amizade;

À Coordenadoria de Aperfeiçoamento de Pessoal de Nível Superior (CAPES), pela concessão da bolsa de estudo;

Aos pesquisadores Mônica Ferreira de Abreu (IAC), Maria Helena Fermino (FEPAGRO), Quirino Carmello (ESALQ), Clóvis Peixoto (UFBA), Vilson Klein (FAMV/UPF), Ricardo Ferraz (ESALQ), Roberto Salva (FUNDECITRUS), Mara Iritani (UNESP), Daniel Bonotto (UNESP), Jailson Cruz (EMBRAPA), Niuro Ribeiro (UNESP) e Marcio Costa Alberto (UNESP) pelos esclarecimentos, indicações e fornecimento de dados. 


\section{SUMÁRIO}

Página

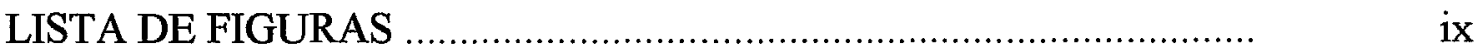

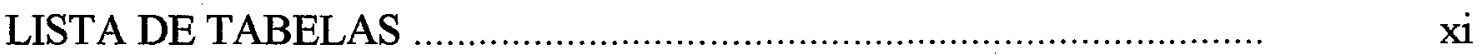

LISTA DE ANEXOS ................................................................... xiii

LISTA DE APÊNDICES............................................................... xiv

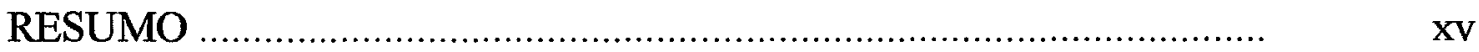

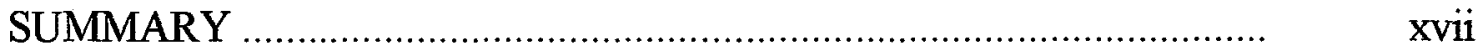

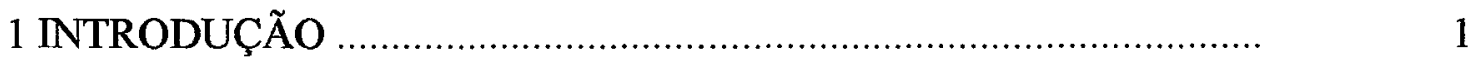

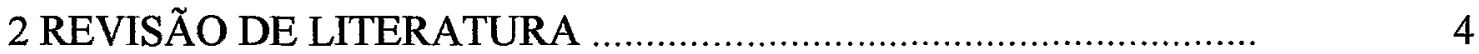

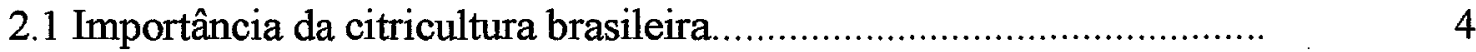

2.2 Problemas fitossanitários e a produção de mudas sadias...................... 5

2.3 Atual legislação da produção de mudas cítricas.....................................

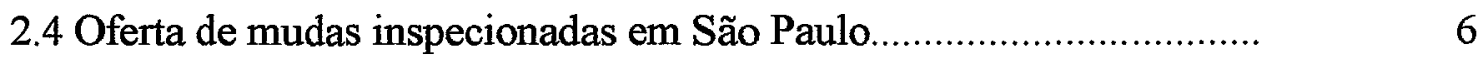

2.5 Água de irrigação para obtenção de mudas sadias............................. 7

2.6 Importância da utilização das águas subterrâneas na agricultura.........

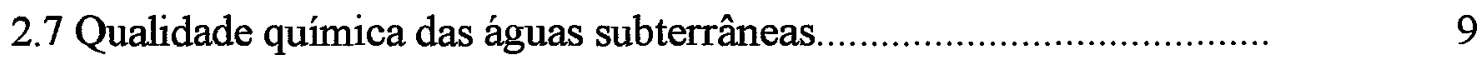

2.8 Meio de cultivo e tecnologia da irrigação no novo sistema de

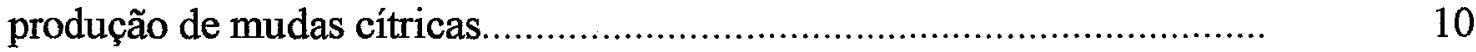

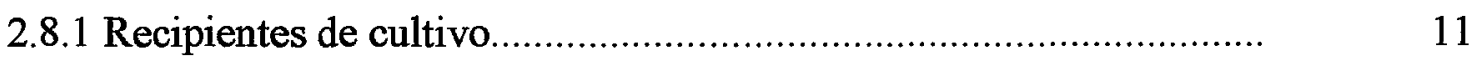

2.8.2 Substratos para cultivo e suas propriedades................................... 12

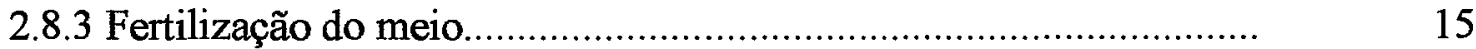




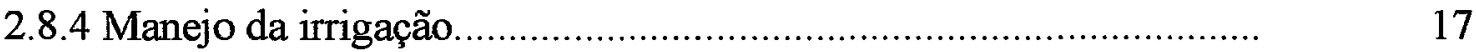

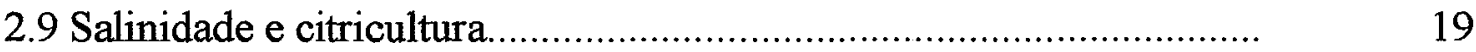

2.10 Variedades cítricas estudadas..................................................... 21

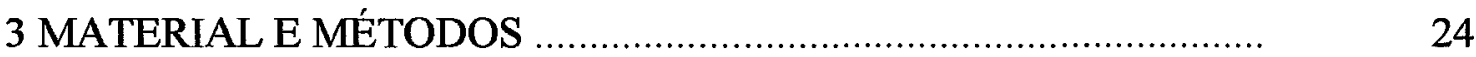

3.1 Localização e caracterização da área experimental.............................. 24

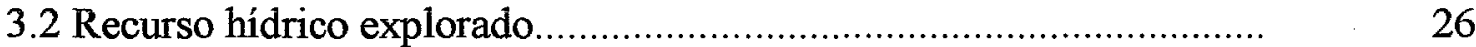

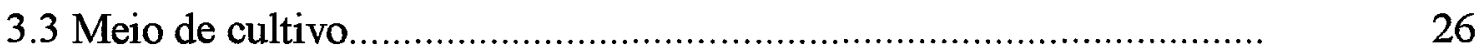

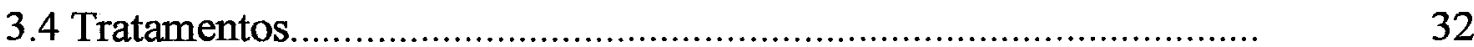

3.5 Delineamento estatístico adotado......................................................

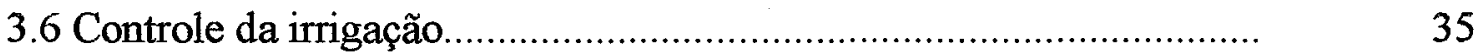

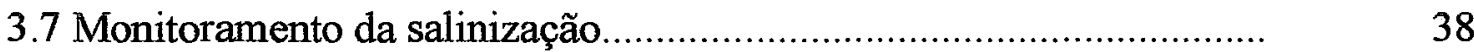

3.8 Avaliação do desenvolvimento das mudas.............................................

4 RESULTADOS E DISCUSSÃO …....................................................

4.1 Lâminas aplicadas e taxas de lixiviação.....................................................

4.2 Evolução da salinidade ao longo do período experimental...................

4.3 Parâmetros de avaliação do desenvolvimento............................................. 48

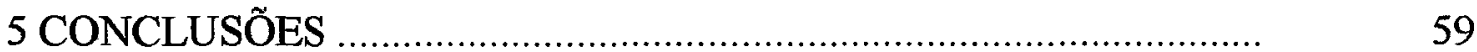

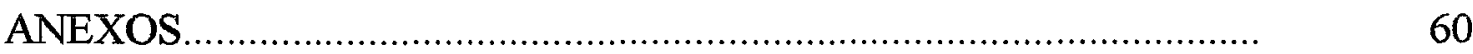

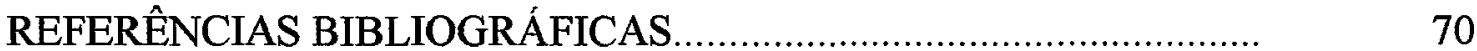

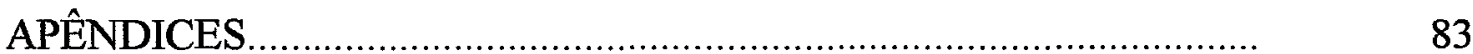




\section{LISTA DE FIGURAS}

Página

1 Vista aérea das estufas da Citrograf Mudas em Rio Claro-SP.............. 24

2 Vista do interior da estufa utilizada na experimentação........................ 25

3 Plântula de citrumeleiro 'Swingle' em tubete....................................... 27

4 Detalhe da concentração do fertilizante na parte superior do meio de cultivo

5 Grânulos do fertilizante de liberação controlada, utilizado no experimento

6 Equipamento de osmose reversa utilizado para dessalinização da

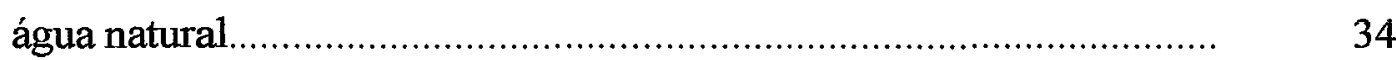

7 Balança utilizada para pesagem das mudas......................................... 37

8 Sistema de coleta para água drenada ................................................. 37

9 Lâmina de irrigação acumulada por porta-enxerto ao longo do

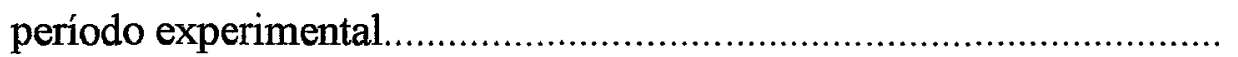

10 Taxas de lixiviação diárias e médias registradas para os portaenxertos 'Cleópatra' (CL), 'Cravo' (CR) e 'Swingle' (SW) no experimento.

11 Condutividade elétrica da água lixiviada para os tratamentos com o porta-enxerto tangerineira 'Cleópatra' ao longo do experimento.......... 
12 Condutividade elétrica da água lixiviada para os tratamentos com o pota-enxerto limoeiro 'Cravo' ao longo do experimento.......................

13 Condutividade elétrica da água lixiviada para os tratamentos com o porta-enxerto 'Swingle' ao longo do experimento..

14 Sintomas detectados em algumas folhas baixeiras de limoeiro 'Cravo'.

15 Sintomas detectados em algumas folhas baixeiras de citrumeleiro 'Swingle'.

Al Sacola de polietileno preto usada nos experimentos (a) e sua forma cilíndrica (b) assumida após enchimento com substrato.

A2 Efeito da salinidade da água de irrigação (CEa) sobre a salinidade média do solo (CEes) na zona radicular para várias frações de lixiviação (FL). 


\section{LISTA DE TABELAS}

Página

1 Caracterização físico-química do substrato orgânico.............................. 29

2 Caracterização química do substrato conforme os procedimentos rotineiros para análise de solo

3 Composição química do fertilizante de liberação controlada

4 Altura inicial dos porta-enxertos (27/02/2003) avaliados antes do início da experimentação.

5 Tratamentos aos quais foi submetido o porta-enxerto 'Cleópatra'.......

6 Tratamentos aos quais foi submetido o porta-enxerto 'Cravo'

7 Tratamentos aos quais foi submetido o porta-enxerto 'Swingle'......... 33

8 Esquema da análise de variância

9 Resultado da análise do extrato de saturação do substrato, por tratamento, realizada ao final do experimento.

10 Alturas médias dos porta-enxertos $(\mathrm{cm})$ produzidos conforme o manejo da empresa em comparação com os produzidos no experimento 
11 Médias de valores tomados aos 41 DAT para: a altura do portaenxerto (ALT), o diâmetro do porta-enxerto (D), a matéria seca das raízes (MSR), a matéria seca da parte aérea (MSPA), a matéria seca total (MST) e a relação de massas secas das raízes e da parte aérea (R/PA)

12 Médias de valores tomados aos 63 DAT para: a altura do portaenxerto (ALT), o diâmetro do porta-enxerto (D), a matéria seca das raízes (MSR), a matéria seca da parte aérea (MSPA), a matéria seca total (MST) e a relação de massas secas das raízes e da parte aérea (R/PA)

13 Médias de valores tomados aos 85 DAT para: a área foliar (AF), a altura do porta-enxerto (ALT), o diâmetro do porta-enxerto (D), a matéria seca das raízes (MSR), o acúmulo de matéria seca da parte aérea (MSPA), a matéria seca total (MST) e a relação de massas secas das raízes e da parte aérea (R/PA).

14 Número de folhas sintomáticas por tratamento, aos 30 DAT

15 Resultados da análise foliar para os três porta-enxertos, por tratamento. 


\section{LISTA DE APÊNDICES}

Página

1 Dados do monitoramento da condutividade elétrica para os três tipos de águas de irrigação sem nitrato de cálcio

2 Dados do monitoramento da condutividade elétrica para os três tipos de águas de irrigação com nitrato de cálcio.

3 Volumes e lâminas de irrigação diários e acumulados por portaenxerto durante o experimento

4 Taxas de lixiviação por porta-enxerto durante o experimento

5 Dados do acompanhamento da condutividade elétrica da água drenada (CEdr) por tratamento ao longo do experimento.

6 Valores medidos em cada parcela para os parâmetros de avaliação do desenvolvimento dos porta-enxertos aos 41 DAT e resumo da análise de variância

7 Valores medidos em cada parcela para os parâmetros de avaliação do desenvolvimento dos porta-enxertos aos 63 DAT e resumo da análise de variância.

8 Valores medidos em cada parcela para os parâmetros de avaliação do desenvolvimento dos porta-enxertos aos $85 \mathrm{DAT}$ e resumo da análise de variância. 


\section{LISTA DE ANEXOS}

Página

A Exigências mínimas para a produção de mudas cítricas em São Paulo

B Resultados da análise química da água natural...................................

C Resultados da análise química da água dessalinizada. 64

D Resultados da análise química da água residual.................................. 65

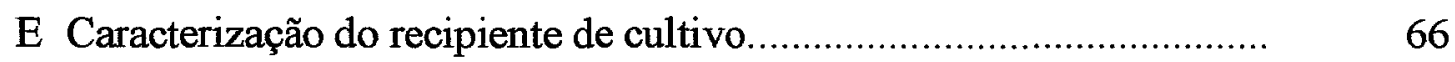

F Memória de cálculo para o nível de cálcio estudado.............................. 67

G Memória de cálculo para a fração de lixiviação almejada..................... 68 


\title{
DESENVOLVIMENTO DE TRÊS PORTA-ENXERTOS CÍTRICOS UTILIZANDO ÁGUAS SALINAS
}

\author{
Autor: TALES MILER SOARES \\ Orientador: Prof. Dr. SERGIO NASCIMENTO DUARTE
}

\section{RESUMO}

Dentre as normas do novo sistema de produção de mudas cítricas do Estado de São Paulo, prega-se que a água de irrigação deve ser isenta de organismos comprovadamente nocivos aos citros, o que se pode garantir utilizando água tratada com cloro ou proveniente de poço tubular profundo. Considerando que as águas subterrâneas podem conter níveis significativos de sais, desenvolveu-se o presente trabalho com o objetivo de avaliar o crescimento dos porta-enxertos cítricos limoeiro 'Cravo', tangerineira 'Cleópatra' e citrumeleleiro 'Swingle', submetidos à irrigação com águas salinas, mensurando se o nitrato de cálcio mitiga eventuais efeitos dos íons tóxicos $\mathrm{Na}^{+} \mathrm{e} \mathrm{Cl}^{-}$. O experimento foi conduzido nas instalações de uma empresa produtora de mudas cítricas durante cerca três meses. Foram investigados três tipos de água: água natural $\left(\mathrm{CE}_{\mathrm{a}} 1,19 \mathrm{dS} \mathrm{m}^{-1}\right)$, explorada diretamente de um poço tubular profundo, água dessalinizada $\left(\mathrm{CE}_{\mathrm{a}} 0,02 \mathrm{dS} \mathrm{m}^{-1}\right)$, obtida mediante osmose reversa da água natural, e água residual $\left(\mathrm{CE}_{\mathrm{a}} 2,11 \mathrm{dS} \mathrm{\textrm {m } ^ { - 1 }}\right)$, resultante do processo de dessalinização. Os níveis de nitrato de cálcio avaliados foram 0 e $20 \mathrm{meq} \mathrm{L}^{-1}$, conformando-se um esquema estatístico fatorial $3 \quad x \quad 3 \quad x \quad 2 \quad$ (tipo 
de porta-enxerto, tipo de água e adição de nitrato de cálcio). As plantas foram desenvolvidas em sacolas plásticas preenchidas com substrato à base de casca de Pinus, fertilizado com adubo de liberação controlada. Os parâmetros usuais para avaliação de crescimento vegetal foram averiguados, não sendo demonstradas, pelo teste de Tukey a 5\%, diferenças significativas, entre os tratamentos, decorrentes da qualidade da água, muito embora se tenha observado que esta contribuiu para o aumento da condutividade elétrica da solução do substrato (CEes) ao longo do período experimental, ultrapassando, inclusive, o valor da salinidade limiar (CEes = $1,4 \mathrm{dS} \mathrm{m}^{-1}$ ) difundido na literatura especializada para os citros. A adição corretiva de nitrato de cálcio não incrementou o crescimento das mudas, atuando, ao contrário, negativamente nas primeiras avaliações de crescimento do sistema radicular e de engrossamento do caule. Em relação ao tipo de porta-enxerto, verificou-se maior desenvolvimento do limoeiro 'Cravo', seguido pelo citrumeleiro 'Swingle' e por último pela tangerineira 'Cleópatra'. Não foram registrados sintomas de toxidez que pudessem ser atribuídos à absorção radicular de sódio e/ou de cloro. $\mathrm{O}$ curto período necessário ao crescimento dos porta-enxertos, proporcionado pelo novo sistema de produção, associado às irrigações freqüentes e suas taxas de lixiviação, além da baixa CTC da casca de Pinus, podem ter restringido os efeitos negativos das águas salinas investigadas. 


\title{
CITRUS ROOTSTOCKS GROWTH USING SALTY WATER
}

\author{
Author: TALES MILER SOARES \\ Adviser: Prof. Dr. SERGIO NASCIMENTO DUARTE
}

\section{SUMMARY}

Among the norms for new systems for citrus nursery tree production in São Paulo State, Brazil, it establishes that irrigation water must be free of noxious organisms. For that, it is recommended to use treated or underground water. Considering that the underground waters can contain significant salt levels, the present work was developed with the objective of evaluating citrus rootstocks growth ('Rangpur' lime, 'Cleopatra' mandarin and 'Swingle' citrumelo), submitted to irrigation with saline waters, measuring also if calcium nitrate mitigates eventual toxic effects caused by $\mathrm{Na}^{+}$and $\mathrm{Cl}^{-}$. The experiment was carried out, during about three months, in a commercial greenhouse. Three water types were investigated: natural water $\left(\mathrm{CEw}=1,19 \mathrm{dS} \mathrm{m}^{-1}\right)$, explored directly from a deep tubular well, desalinized water $\left(\mathrm{CEw}=0,02 \mathrm{dS} \mathrm{m}^{-1}\right)$, obtained by reverse osmosis from the natural water, and residual water $\left(\mathrm{CEw}=2,11 \mathrm{dS} \mathrm{m}^{-1}\right)$, resultant from desalinization process. The calcium nitrate evaluated levels were 0 and 20 meq $\mathrm{L}^{-1}$, conforming to a factorial statistical design $3 \times 3 \times 2$ (rootstock type, water quality and calcium nitrate addition). Plants were developed in soft polyethylene bags filled with substrate 
mainly composed of Pinus bark, fertilized by slow-release fertilizer. Usual parameters for plant growth evaluation were measured. According with Tukey test at $5 \%$ probability, water quality did not affect rootstocks development, although the water type have contributed to increase the electric conductivity of solution (CEes) along the experimental period, surpassing, the salinity threshold value (CEes $=1,4$ $\mathrm{dS} \mathrm{m} \mathrm{m}^{-1}$ ) reported for citrus in specialized literature. The calcium nitrate corrective addition did not increase the plant growth, acting, to the opposite, negatively in the first evaluations of root and stem diameter development. Relative to rootstock type, it was verified larger development for 'Rangpur' lime, followed for 'Swingle' citrumelo' and last for the 'Cleopatra' mandarin. Symptoms that could be attributed to the $\mathrm{Cl}^{-}$and/or $\mathrm{Na}^{+}$root absorption were not registered. The short time necessary to rootstocks growth provided by new production system, associated to the frequent irrigations and its leaching rates, besides the low cation exchange capacity of Pinus bark, may have possibly restricted the saline waters negative effects. 


\section{INTRODUÇÃ̃o}

Para se manter como o maior produtor de citros, o Brasil tem disponíveịs condições climáticas favoráveis e um reconhecido suporte científico, que não obstante, colocam-no na vanguarda tecnológica da citricultura mundial. Tem-se a considerar, entretanto, que as condições climáticas brasileiras beneficiam não apenas o desenvolvimento vegetal, mas também pragas e doenças, as quais, em virtude da magnitude do parque citrícola nacional, podem eventualmente adquirir ainda maiores relevâncias econômica e social.

Na história contemporânea da citricultura brasileira, a morte súbita dos citros vem causando grande preocupação aos produtores, pois cerca de $85 \%$ dos pomares estão instałados sobre limoeiro 'Cravo", que seria o porta-enxerto mais suscetível à doença. Na década passada, a clorose variegada dos citros levou à morte e à erradicação de milhões de plantas, causando enorme prejuízo aos citricultores.

Eventos históricos como estes indicam que a produção de mudas cítricas já seria uma atividade imprescindível tão somente pela necessidade de reposição de novas plantas aos pomares afetados. Por outro lado, tem-se a acrescentar ainda que as mudas podem ser uma das principais vias de disseminação de pragas e patógenos, conferindo à atividade um caráter também estratégico.

Neste sentido, ałguns Estados do Brasil começam a implantar programas de regulamentação para a produção de mudas cítricas. Em São Paulo, a Agência de Defesa Agropecuária (ADAESP) tornou obrigatória a produção de mudas cítricas em ambiente protegido, mediante a Portaria ADAESP 1, de 10 de fevereiro de 2003. No 
Estado de São Paulo, as mudanças tecnológicas na produção de mudas cítricas estabelecem, dentre outras normas, que a água de irrigação deve ser isenta de nematóides, fungos do gênero Phytophthora e outros patógenos comprovadamente nocivos aos citros.

Para assegurar a qualidade sanitária da água de irrigação para mudas cítricas, preconiza-se seu tratamento com cloro ou a utilização de recurso subterrâneo.

Deve-se ponderar, contudo, que embora as águas subterrâneas atendạm qualitativamente aos aspectos fitossanitários para obtenção de mudas sadias de citros, sua qualidade química (concentração de sais) pode ser limitante ao desenvolvimento vegetal.

É freqüente o acúmulo de sais em solos cultivados sob ambiente protegido quando as práticas da irrigação e da fertilização são manejadas incorretamente. Como alternativa à recuperação do solo salinizado, que é dispendiosa, os produtores podem mudar a localização das estufas na propriedade ou substituir o solo de cultivo. No caso específico da produção de mudas cítricas em recipientes, o acúmulo de sais no meio de cultivo não se torna importante pelas dificuldades em se recuperá-lo, já que este é vendido com a muda. Hipotetiza-se, porém, que o desenvolvimento das mudas em meio moderadamente salino deve ser retardado, o que aumentaria o tempo para sua comercialização, reduzindo a renda operacional do produtor por área de estufa ocupada.

Os citros são classificados como sensíveis às águas salinas, mas os efeitos dessas águas sobre a citricultura parecem variar com os genótipos estudados e mesmo entre investigações, não sendō possível extrapolar para o Brasil os resultadọs obtidos em outros países, onde as condições climáticas e de produção são distintas, e onde se utilizam diferentes variedades como porta-enxertos e copas.

Neste sentido, tendo em vista a obrigatoriedade da produção de mudas cítricas em ambiente protegido, associada à alternativa de utilização de águas subterrâneas para sua irrigação, prevista pelo novo Programa de Produção de Mudas 
Cítricas de São Paulo, torna-se necessário avaliar a influência da qualidade química da água no desenvolvimento das mudas. Considerando as premissas expostas, objetivou-se com o presente trabalho:

-Avaliar a produção de porta-enxertos de limoeiro 'Cravo", tangerineira 'Cleópatra' e citrumeleiro 'Swingle', submetidos à influência de águas salinas; e

- Verificar se a aplicação de nitrato de cálcio mitiga os eventuais prejuízos da toxidez causada pelos excessos de cloro e sódio na água de irrigação. 


\section{REVISÃO DE LITERATURA}

\subsection{Importância da citricultura brasileira}

O Brasil é o maior produtor mundial de frutas cítricas, com uma produção de 20,251 milhões de toneladas, correspondente a 19,38 \% da produção mundial, registrada em 2002 (FAO, 2003). No comércio internacional de suco concentrado de laranja, principal produto da citricultura, o país responde por cerca de $80 \%$ (Estanislau et al., 2001), sendo que o setor citrícola em 2000 participou com 2\% do total das exportações brasileiras e com $6 \%$ entre os produtos do agronegócio.

Neves et al. (2001), analisando dados estatísticos consolidados de 1996 a 2000 , revelam a importância da cadeia agroindustrial citrícola no Brasil, mediante a movimentação de recursos alocativos e distributivos, considerando a geração de empregos, a formação de capital e renda, a agregação de valor regional, a ativação do setor terciário (serviços, transporte, comércio, etc) e a interiorização do desenvolvimento, principalmente no Estado de São Paulo, onde a citricultura tem expressivo impacto na economia e na balança comercial: Informam os autores que, por produto exportado, verifica-se que o suco concentrado tem se posicionado entre os principais produtos de exportação em termos de divisas geradas e, embora pouco conhecido, por diversos anos, posicionou-se em primeiro lugar nas exportações paulistas, perdendo apenas recentemente (anos de 1999 e 2000) esta posição para a indústria aeronáutica. 


\subsection{Problemas fitossanitários e a produção de mudas sadias}

A despeito da consolidação do maior parque citrícola do mundo em São Paulo, a produtividade dos pomares no Estado vem sendo sensivelmente prejudicada, como informam Borges et al. (2000), pela crescente incidência de patógenos, especialmente a bactéria Xylella fastidiosa, causadora da clorose variegada dos citros $(\mathrm{CVC})$, o que tem provocado a erradicação de milhões de árvores nos últimos anos. Mais recentemente, a morte súbita dos citros (Müller et al., 2002), vem se alastrando rapidamente e preocupando os citricultores, especialmente porque vem sendo o limoeiro 'Cravo', sustentáculo de $85 \%$ dos pomares nacionais, o portaenxerto mais suscetível à doença.

Neste cenário, a produção de mudas não apenas é importante para a renovação dos pomares afetados. Não obstante, são as mudas e outros tipos de propágulos infectados uma das principais vias de disseminação de pragas e doenças para qualquer cultura, devendo-se ressaltar, então, que a produção de mudas sadias é uma atividade de caráter também estratégico para o controle fitossanitário.

No caso específíco da cultura dos citros, segundo Valle (2002), a existência de viveiros mantidos a céu aberto e de cigarrinhas transmissoras nessas áreas constituiu o principal fator para o agravamento do cenário da CVC em São Paulo. Acrescenta o autor que a comercialização de mudas infectadas provocou a disseminação da doença em regiões anteriormente não contaminadas, convergindo para um quadro de extrema gravidade.

Justamente fomentada para que se contivesse o avanço da $\mathrm{CVC}$, visando também uma solução aos problemas relativos a patógenos de solo como fungos do gênero Phytophthora e nematóides, a Certificação de Mudas Cítricas foi instituída pela Secretaria de Agricultura e Abastecimento de São Paulo, em 1994 (CATI, 1994). Paralelamente à certificação, de caráter voluntário (Graf, 2001), era implantado também o Programa de Mudas Cítricas Fiscalizadas, que não tinha os mesmos requisitos da certifícação, mas que contribuiu para a evolução da 
conscientização dos produtores na adoção de medidas quarentenárias, apresentando caráter compulsório.

\subsection{Atual legislação da produção de mudas cítricas}

Cumprindo um calendário progressivo em relação às exigências, a partir de janeiro de 2003, conforme portaria específica, as normas estabelecidas para a produção de mudas certificadas passaram também a valer para a produção de mudas físcalizadas. Ficou, então, proibida, a partir daquela data, a produção e comercialização de mudas produzidas em viveiros a céu aberto (Carvalho, 2003). A Agência de Defesa Agropecuária de São Paulo (ADAESP) regulamentou a partir de fevereiro de 2003, mediante a portaria ADAESP 1, que para a produção de mudas cítricas se deve atender a uma série de exigências básicas (Anexo A), as quais além de tornar compulsório a produção sob ambiente protegido, pregam o uso recipientes de cultivo e a utilização de substratos e água de irrigação livres de pragas e patógenos comprovadamente nocivos aos citros.

Visando a excelência da atividade, o novo Programa de Produção de Mudas Fiscalizadas/Certificadas (Carvalho, 2003) prevê importantes restrições aos produtores que não atenderem suas deliberações, podendo caber, em função da gravidade da infração: proibição da comercialização de produto, interdição do viveiro e do depósito, apreensão de produto, destruição de produto e multa.

\subsection{Oferta de mudas inspecionadas em São Paulo}

Atualmente, a demanda em São Paulo é de 12 milhões de mudas cítricas anualmente (FUNDECITRUS, 2003), mas este número pode crescer em alguns anos, segundo Mourão Filho et al. (1998), para até 30 milhões de mudas. 
Os resultados da última inspeção feita pela FUNDECITRUS indicaram a presença de 10.396.680 mudas em viveiros telados, correspondentes a 99,87\% das mudas inspecionadas. Considerando o número de cavalinhos em viveiros telados, 13.968.789 plântulas correspondentes a $99,55 \%$ das inspecionadas (FUNDECITRUS, 2003), tem-se a auto-sustentabilidade do Estado em mudas cítricas sadias, o que confirma, após a gravidade dos problemas fitossanitários supracitados, a capacidade de re-organização do setor citrícola paulista, mediante aportes financeiro, científico e jurídico, que conduziram ao estabelecimento de novas preconizações na cadeia produtiva a iniciar-se pela produção das mudaś.

\section{5 Água de irrigação para obtenção de mudas sadias}

Dentre os principais requisitos para obtenção da certificação, teve-se sempre como compulsório a utilização de substrato e água de irrigação livres de patógenos (Graziano, 1998). Para atender às normas, e evitar contaminar as mudas com patógenos disseminados via água (principalmente Phytophthora, agente causal da gomose, e nematóides), preconiza-se o tratamento da água de irrigação com cloro a 5 ppm ou a utilização de água de poço tubular profundo (FUNDECITRUS, 2003; Oliveira et al., 2001; Graf, 2001).

Torna-se importante vislumbrar que a água subterrânea não é apenas um recurso alternativo de garantia à qualidade sanitária vegetal, tratando-se ainda de um recurso cada vez mais recorrido em decorrência da demanda hídrica pelas mais distintas atividades humanas. Neste sentido, torna-se provável que muitos produtores aceitem a alternativa de utilização de águas subterrâneas para a produção de mudas cítricas, seja na implantação dos viveiros, seja na sua adaptação à atual legislação e/ou à demanda de água. 


\subsection{Importância da utilização das águas subterrâneas na agricultura}

Lembrando diversos pesquisadores, informam Paz et al. (2000) que as taxas de crescimento da população mundial vêm superando as taxas de crescimento da oferta de alimentos. Para fortalecer a segurança alimentar e evitar um número cada vez maior de famintos, tem-se como alternativas: aumentar a área de exploração e/ou incrementar a produtividade nas áreas já estabelecidas. Para aumentar as produtividades dos cultivos, tem-se como consenso que a irrigação é uma das mais consistentes práticas agrícolas.

Por outro lado, ressalvam Ayers \& Westcot (1999), que a agricultura irrigada depende tanto da quantidade quanto da qualidade da água. No entanto, para estes autores, o aspecto da qualidade tem sido desprezado devido ao fato de que, no passado, em geral as fontes de água eram abundantes, de boa qualidade e de fácil utilização. Esta situação, todavia, está se alterando em muitos lugares. O uso intensivo de praticamente todas as águas de boa qualidade implica que, tanto nos projetos novos como nos antigos que requerem águas adicionais, tem-se que recorrer às águas de qualidade inferior, incluindo as salinas. Além disto, num cenário em que a oferta de água tende a ser limitante, segundo Paz et al. (2000), prioriza-se a utilização das águas de melhor qualidade para o abastecimento humano.

Respeitando as projeções de consumo de água, que dobraria a cada 20 anos (Maia Neto, 1997) e, atentando-se para a redução quantitativa e qualitativa das águas superficiais, tem-se como consenso que as águas subterrâneas serão cada vez mais utilizadas. Neste sentido, alertam Ayers \& Westcot (1999), que para evitar problemas conseqüentes, deve existir planejamento efetivo que assegure o melhor uso possível das águas, de acordo com sua qualidade. 


\subsection{Qualidade química das águas subterrâneas}

Embora as águas subterrâneas possam atender qualitativamente aos aspectos fitossanitários para obtenção de mudas certificadas/fiscalizadas de citros, conforme especifica as portarias ADAESP 2 e ADAESP 3 (Carvalho, 2003), deve-se ponderar que sua qualidade química (concentração de sais) pode ser limitante ao desenvolvimento vegetal.

É sabido que as reservas subterrâneas são abastecidas por infiltração lenta das águas superficiais, através dos solos e se acomodam em camadas rochosas a diferentes profundidades, sendo mantidas, muitas vezes, sob pressão (Holanda \& Amorim, 1997). Portanto, a qualidade química das águas subterrâneas depende da concentração inicial de sais na água de recarga e, principalmente, das características dos solos e das rochas que as confinam. Justamente em virtude da variabilidade espacial sobre as características do solo e da sua matriz, tem-se a variabilidade qualitativa das águas subterrâneas disponíveis.

As águas subterrâneas do Estado de São Paulo apresentam, de um modo geral, baixa salinidade e características físicas, químicas e biológicas adequadas ao abastecimento público. Há, no entanto, algumas peculiaridades na caracterização dos tipos hidroquímicos segundo os sistemas de aqüíferos. Observa-se a ocorrência de águas cloretadas e/ou sulfatadas sódicas no extremo sudoeste do Estado (aqüifero Botucatu $^{1}$ ), no aquitardo ${ }^{2}$ Passa-Dois, nos sedimentos litorâneos e na faixa costeira do aqǘfero cristalino. Predominantemente bicarbonatadas cálcicas, as águas do aqüífero Botucatu, embora fracamente mineralizadas, apresentam enriquecimento salino desde a sua recarga (leste) até a região de forte confinamento (oeste). A oeste, as águas tornam-se bicarbonatadas sódicas, evoluindo no extremo sudoeste do

\footnotetext{
${ }^{1}$ Aqüífero Botucatu é a denominação atribuída à porção do aqüífero Guarany no Estado de São Paulo.

${ }^{2}$ Aqüífero é toda formação geológica com capacidade de armazenar e transmitir água. Já aquitardo é a denominação dada a formação geológica que pode armazenar água, mas que a transmite lentamente.
} 
território para cloro-sulfatadas sódicas com aumento de salinização para até $650 \mathrm{mg}$ $\mathrm{L}^{-1}$ de resíduo seco (DAEE, 1988).

Mesmo em regiões de menor abrangência territorial, pode-se encontrar significativa heterogeneidade na qualidade química das águas. Oliveira \& Salati (1981), estudando poços tubulares profundos tão somente na região de Piracicaba SP, classificaram águas de qualidades satisfatória, utilizável e não utilizável para fins de irrigação, devendo-se registrar que as águas de pior qualidade foram principalmente ricas em cloro (concentração de até 32,4 meq $\mathrm{L}^{-1}$ ) e sódio (concentração de até 56,5 meq $\mathrm{L}^{-1}$ ), atingindo valores de condutividade elétrica às vezes superiores a $3 \mathrm{dS} \mathrm{m}^{-1}$.

\subsection{Meio de cultivo e tecnologia da irrigação no novo sistema de produção de mudas cítricas}

A modernização do sistema de produção de mudas cítricas como interface aos seus produtores, aos consumidores e à ciência, tem demonstrado o aporte científico da citricultura brasileira, conduzido à elaboração de vários trabalhos almejando mudas cada vez mais vigorosas, mais precoces, menos onerosas e sadias.

Integrada à obrigatoriedade da produção de mudas cítricas em ambiente protegido, o que exige alto investimento em instalações (estufas, bancadas, sistema de irrigação, entre outros) (Graf, 2001), testemunha-se entre os viveiristas a necessidade de mudanças tecnológicas, destacando-se as que se devem efetuar no manejo da irrigação e das adubações. Esta modernização é necessária já que o novo programa de produção de mudas estabelece o uso de substrato e de recipientes de cultivo, fatores que, associados ao balanço energético (evapotranspiração) sob ambiente protegido, concorrem para a utilização de técnicas até então desconsideradas e, não obstante, para novos objetos de investigação. 


\subsubsection{Recipientes de cultivo}

A produção de mudas cítricas em recipientes de cultivo sob ambiente protegido é uma técnica atribuída à Universidade da Califórnia, conforme Nauer et al. (1968), objetivando-se a produção de plântulas para programas de melhoramento. A difusão dessa técnica para viveiros comerciais norte-americanos se deu a partir de 1977 (Castle \& Ferguson, 1982), em decorrência das vantagens proporcionadas em relação ao sistema tradicional de produção no solo e a céu aberto.

Estas vantagens se relacionam ao crescimento mais rápido das mudas, em substratos especialmente elaborados, ao melhor controle de infecções causadas por patógenos e pragas, ao melhor controle da nutrição, à melhor qualidade do sistema radicular pelo menor traumatismo provocado no transplante, à utilização permanente do mesmo local para produção, e ao cultivo de até 10 vezes mais plantas por unidade de área ocupada (Platt \& Opitz, 1973; Moore, 1978; Castle \& Ferguson, 1982; Castle \& Rouse, 1990). As desvantagens mais relevantes são atribuídas: à produção de mudas relativamente menores, tornando-se necessários cuidados pós-plantio; à necessidade de transplante para recipientes maiores a fim de se evitar enovelamento de raízes, para mudas que permanecerão por mais tempo no viveiro; ao custo mais elevado das mudas devido a infra-estrutura e a maior necessidade de investimento (Moore, 1978; Castle \& Ferguson, 1982).

Ainda que a nova legislação, sobre a produção de mudas cítricas, não trate das dimensões mínimas para o recipiente de cultivo, estas foram estabelecidas pela legislação precursora, na Portaria CATI- $7^{3}$, de 10 de fevereiro de 1998 , em $10 \mathrm{~cm}$ de largura e $30 \mathrm{~cm}$ de altura.

Recipientes plásticos rígidos com 14 a $15 \mathrm{~cm}$ de boca, especialmente projetados para a formação de mudas cítricas, conhecidos como citropotes $(4,5 \mathrm{~L})$ e citrovasos $(3,8 \mathrm{~L})$, podem apresentar vantagens em relação às sacolas plásticas

\footnotetext{
${ }^{3}$ Diário Oficial do Estado, Poder Executivo, Seg I, São Paulo, 108 (31) sexta-feira, 13 de fevereiro de 1998. p.12.
} 
(perfuradas e sanfonadas), por possuírem estrias longitudinais que direcionam as raizes para o fundo, evitando o enovelamento. $\mathrm{O}$ emprego de sacolas plásticas, além do menor custo, tem a vantagem de se tratar de material descartável, sem necessidade de retorno e realização de lavagens e desinfestações para novos usos. Para o uso das sacolas, entretanto, deve-se observar com maior cuidado o tempo máximo de permanência das mudas, evitando-se enovelamento das raízes e a necessidade de toaletes ou cortes, que podem tornar as mudas mais suscetíveis a doenças causadas por fungos de solo (Carvalho, 1998).

Deve-se atentar também para outras características dos recipientes, como forma, largura e material de fabricação, pois influenciam a 'capacidade de container', ainda que a altura, conforme Fermino (2002), seja preponderante sobre as relações água-ar no substrato confinado no recipiente.

Trabalhando com sete sacolas plásticas com capacidade variando entre 3 a 5,8 L de substrato, Girardi et al. (2001a) concluíram, para a produção de mudas cítricas, pelo uso daquelas que comportam $5 \mathrm{~L}$, argumentando serem mais apropriadas as de dimensões $25 \times 32 \mathrm{~cm}$, pois permitem melhor aeração e distribuição de luz às plantas, em comparação às de dimensões $20 \times 40 \mathrm{~cm}$ e de mesma capacidade volumétrica.

\subsubsection{Substratos para cultivo e suas propriedades}

No Brasil, o substrato é um insumo relativamente novo. Produtores e viveiristas do setor de produção de plantas em ambientes protegidos já comprovaram na prática as vantagens da formação das mudas em recipientes: melhores condições fitossanitárias, menores índices de perda no campo após transplante e aumento da produtividade (Abreu et al., 2002).

Cascas compostadas de Pinus, areia grossa, ou uma mistura destes, são os mais comuns substratos de cultivo para mudas cítricas na África do Sul, enquanto a turfa de Sphagnum, sozinha ou combinada com perlita, vermiculita e grânulos de 
Styrofoam predominam na América do Norte e Europa. No Brasil, as misturas mais comuns são baseadas em casca de Pinus compostada, turfa negra regional e vermiculita (Tavieira, 2001). O uso de fibras de coco no desenvolvimento de mudas cítricas vem sendo também empregado e investigado por pesquisadores (Tavieira, 2001; Zanetti et al., 2003).

Segundo a classificação apresentada por Martínez (2002), em função da CTC, as cascas de Pinus, as fibras de coco, as turfas e a vermiculita são substratos quimicamente ativos, enquanto a areia e a perlita são inertes.

Conforme Cadahía \& Eymar (1992) ${ }^{4}$, citados por Martínez (2002), a CTC de um substrato quando inferior a $75 \mathrm{meq} 100 \mathrm{~g}^{-1}$ é caracterizada como baixa; entre $75 \mathrm{e}$ $100 \mathrm{meq} 100 \mathrm{~g}^{-1}$ como intermediária; e acima de $100 \mathrm{meq} 100 \mathrm{~g}^{-1}$ como alta. Para casca de Pinus, a CTC divulgada por Martínez (2002) pode ser classificada como baixa, calculada em torno de $55 \mathrm{meq} 100 \mathrm{~g}^{-1}$, o que corresponde a $5,5 \mathrm{meq} 100 \mathrm{~cm}^{-3}$, considerando a densidade de $0,1 \mathrm{~g} \mathrm{~cm}^{-3}$ informada pelo autor.

Para fase posterior ao transplante dos porta-enxertos, o substrato mais difundido no Brasil para mudas cítricas, confeccionado à base de Pinus, quando analisado conforme os procedimentos de rotina para caracterização de solos, por Bernardi (1999), num ensaio de nutrição, apresentou uma CTC de $6,83 \mathrm{meq} \mathrm{cm}^{-3}$, sendo este valor determinado a partir da soma de bases. Posteriormente, a CTC, assim determinada, foi aceita por Ruschel (2002), também estudando a resposta das mudas cítricas à adubação.

No Brasil, ainda não há definições das características químicas e nem dos métodos a serem utilizados na avaliação da qualidade de substratos e componentes comerciais. A despeito desse fato, os procedimentos baseados no extrato de saturação e extrato 1: 1,5 (v/v) são indicados por possuírem boa base teórica e literatura abundante para interpretação dos dados analíticos para muitos substratos (Abreu et al., 2002).

${ }^{4}$ CADAHÍA, C. \& EYMAR, E. Caracterización química y fisioquímica de sustratos, Actas de Horticultura, v.11, p.19-25, 1992. 
Segundo Abreu et al. (2002), o método do extrato de saturação é a melhor forma para avaliar a disponibilidade de nutrientes em substratos, sendo usado como método de referência em estudos de comparação de métodos. Referenciando Bunt $(1986)^{5}$, Abreu et al. (2002) acrescentam que a maior vantagem desse método está no fato de quantificar os nutrientes prontamente disponíveis às plantas. Por outro lado, ressalvam que o extrato de saturação é bastante trabalhoso e demorado, não sendo adequado para rotina, além de resultar em dados menos reprodutíveis em função da dificuldade de se identificar o ponto final de saturação.

Diferentemente das propriedades químicas, que podem ser modificadas mediante técnicas apropriadas, as características físicas dos substratos não podem ser alteradas durante o desenvolvimento das plantas em recipientes (Cadahía, 2000; Milner, 2002).

Os métodos de determinação das relações ar-água em substratos diferem daqueles empregados para solos. As curvas de retenção de água de solos agrícolas são medidas usualmente em um amplo intervalo de sucções $(0$ a $-1500 \mathrm{kPa})$. Entretanto, as plantas cultivadas em recipientes não podem ser submetidas a tensões hídricas elevadas devido ao volume limitado do meio em que crescem; daí a razão de se determinar as curvas de retenção, para substratos, em intervalos mais estreitos $(0$ a $-100 \mathrm{kPa})$ (Cadahía, 2000).

Os substratos à base de casca de Pinus, empregados nos viveiros de mudas cítricas no Brasil, segundo Milner (2001), contêm, aproximadamente: 10\% de capacidade de aeração, medida à tensão de $-1 \mathrm{kPa}$, e $30 \%$ de água facilmente disponível, medida entre -1 e $-5 \mathrm{kPa}$. Para esses substratos, Milner (2001) informa um valor de $60 \%$, em volume, para 'capacidade de container', que é um conceito distinto de 'capacidade de campo', e que foi desenvolvido por White \& Mastalerz (1966) para definir a umidade remanescente de um substrato, previamente saturado

\footnotetext{
${ }^{5}$ BUNT, A. C. Problems in the analysis of organic and lightweight potting substrates. Hortsicence, v.21, p.229-231, 1986.
} 
com água, e deixado a drenar totalmente até se alcançar um estado de equilíbrio, antes da evaporação.

Segundo Martínez (2002), a 'capacidade de container' está associada à tensão de $-1 \mathrm{KPa}$, correspondendo à umidade tomada à metade da profundidade do substrato. Referenciando Handreck \& Black (1999) ${ }^{6}$, Fermino (2002) acrescenta que a altura da camada saturada independe da altura do recipiente, após saturação e drenagem livre. Dessa desproporcionalidade, explica-se a influência da altura do recipiente sobre a umidade à 'capacidade de container'. Assim, recipientes mais baixos apresentam maior umidade relativa que recipientes mais altos, sendo a altura da camada saturada igual para ambos. Pelo mesmo motivo, a autora elucida o fato de que a 'capacidade de container' é sempre maior que a 'capacidade de campo' para um mesmo material.

\subsubsection{Fertilização do meio}

Quando as mudas são produzidas em recipientes, o crescimento é influenciado pelo volume limitado e pela fertilidade do substrato, além de suas características físicas. Como demonstrado por Rezende et al. (1995), o volume de substrato pode ser compensado pelo aumento nas doses de fertilizantes adicionados.

Conforme Lemaire et al. (1989) ${ }^{7}$, citados por Abad et al. (1992), a capacidade de fertilização em um recipiente, em dado momento, depende da quantidade de água, limitada à capacidade de retenção do substrato, e da quantidade de nutrientes na fase líquida, limitada a uma concentração específica para cada planta (barreira fisiológica).

A solução ao problema da fertilização em recipientes de cultivo passa por: conhecer as características do substrato (físicas, químicas, físico-químicas e

\footnotetext{
${ }^{6}$ HANDRECK, K. A. \& BLACK, N. D. Growing media for ornamental plants and turf. Sydney: UNSW, 1999. 448p.

7 LEMAIRE, F.; DARTIGUES, A; RIVIÈRE, L. M.; CHARPENTIER, S. Cultures em pots et conteneurs. Paris-Limoges: INRA-PHM Revue Horticole, 1989. 184p.
} 
biológicas); conhecer as necessidades nutricionais das espécies vegetais, em suas etapas de desenvolvimento; e conhecer as características dos diferentes tipos de adubos e seu comportamento nas condições de emprego específicas (Abad et al., 1992).

Se a fertirrigação é permanente, a CTC do substrato não constitui vantagem alguma, sendo recomendados materiais inertes, com baixas ou nulas CTC. Por outro lado, se a fertirrigação é intermitente, é conveniente utilizar substratos com moderada a elevada CTC (Cadahía, 2000), em todo caso superior a $20 \mathrm{meq} 100 \mathrm{~g}^{-1}$ (Abad et al., 1992).

Como explica Cadahía (2000), uma elevada CTC aumenta a eficiência da aplicação dos fertilizantes de base durante o processo de fabricação do substrato. Para o autor, quando se usam substratos com baixa CTC, os fertilizantes são aplicados normalmente por meio do sistema de irrigação (fertirrigação).

Para Cadahía (1995), consegue-se freqüentemente um crescimento ótimo das plantas sobre substratos orgânicos, quando uma aplicação moderada de adubos de liberação controlada é complementada com a fertirrigação. Para o caso específico da produção de mudas cítricas em São Paulo, quando se utiliza substrato à base de casca de Pinus com vermiculita, Girardi et al. (2001b) recomendam a aplicação de NPK 22-04-08, na forma de fertilizante de liberação lenta, em dose de $2,5 \mathrm{~kg} \mathrm{~m}^{-3}$.

Boaventura (2003), investigando a marcha de absorção de nutrientes e a curva de crescimento de mudas cítricas submetidas a dois tipos de manejo da adubação, quais sejam, a fertirrigação e aplicação de fertilizantes de liberação controlada (formulação 22-04-08, dosado em $2,4 \mathrm{~kg} \mathrm{~m}^{-3}$ ), encontrou melhor eficiência de manejo, com melhor disponibilidade de nutrientes às plantas, mediante a fertirrigação. Conforme o autor, o manejo com fertilizante de liberação controlada foi prejudicado pelas condições climáticas, que conduziram à rápida difusão dos nutrientes para o meio de cultivo, o que associado às taxas de lixiviação empregadas conduziram ao esgotamento do meio de cultivo, tornando necessária posterior complementação nutricional. 
A distribuição dos nutrientes no substrato está condicionada pela colocação dos emissores de irrigação e pelo manejo da água de acordo com a taxa de transpiração do cultivo e a absorção mineral. Uma dosagem de água adequada à capacidade de retenção do substrato deve permitir uma distribuição homogênea de nutrientes no volume do substrato. Se a irrigação é deficiente, podem ser gerados gradientes verticais de condutividade elétrica ${ }^{8}$, com valores mais elevados na base do recipiente, o que pode diminuir o volume disponível para as raízes (Martínez, 2002).

\subsubsection{Manejo da irrigação}

No emprego de substratos com elevada porosidade total e alta capacidade de aeração, o problema é como conseguir uma disponibilidade suficiente de água em todo momento, sem grandes perdas por drenagem, em sistemas-abertos. Dada a importância de conseguir uma homogênea distribuição de água e nutrientes em todo o volume do substrato, se recomenda como prática usual a irrigação em excesso, que por um lado assegura que a solução chegue a todas as partes, compensando irregularidades da irrigação e, por outro, retira restos de solução anterior, cujo equilíbrio iônico tenha sido modificado pela absorção seletiva das plantas (Martínez, 2002).

Segundo Martínez (2002), considera-se que o excesso de água deve alcançar um mínimo de 15 a 20\%. Já Milner (2001) refere-se à fração de lixiviação abordando tão somente a prevenção ao acúmulo de sais na zona radicular, ressalvando, assim como fazem Ayers \& Westcot (1999), que o montante extra a aplicar depende da qualidade da água e da sensibilidade das plantas aos sais.

Em viveiros para mudas cítricas, a fração de lixiviação usualmente aplicada está entre 10 e $20 \%$, sendo este meio de manejar a irrigação, com controle da salinidade no substrato, amplamente difundido em Israel e outros países, dada sua

\footnotetext{
${ }^{8}$ Parâmetro que serve para avaliar a quantidade de sais-dissolvidos na água; em-soluções e-substratos.
} 
simplicidade, rapidez e eficiência (Milner, 2001). Olic et al. (2001) observaram maior desenvolvimento de mudas cítricas com aplicação de 100 ou $125 \%$ de água em volumes relativos ao necessário para saturação do substrato.

Além do uso da fração de lixiviação, Milner (2002) apresenta a pesagem dos recipientes de cultivo e a tensiometria como ferramentas para o manejo da irrigação em substratos. Segundo o autor, a pesagem dos recipientes permite acompanhar in situ o consumo de água ao longo do dia, o que indica, ao se estabelecer um peso minimo, o 'quando² irrigar. Em relação a tensiometria, o mesmo autor, em 2001, alertou para a utilização de tensiômetros especialmente feitos para trabalhar em baixas tensões, citando os eletrônicos e também aqueles que apresentam forma de ' $\mathrm{L}$ ', pois melhoram a área de contato da cápsula cerâmica com o substrato.

O sistema de irrigação preconizado para produção de mudas cítricas certificadas é o gotejamento (Borges et al., 2000), que evita molhar a parte aérea das plantas, prevenindo a incidência de patógenos, e que proporciona alta efíciência de aplicação de água, sendo também aproveitado para aplicação de fertilizantes (fertirrigação).

Outra importante vantagem da irrigação localizada, apontada por Vermeiren \& Jobling (1980), é a possível utilização de águas salinas, pois permite aplicações de água freqüentemente, mantendo o solo a uma tensão de sucção de água muito baixa, de forma que a concentração de sais no extrato de saturação do solo fique abaixo dos limites perigosos às culturas. Além disso, evita as queimaduras das folhas, ocasionadas quando se asperge água salina.

Proporcionar poucas perdas de água é um benefício insofísmável do gotejamento, mas que pode favorecer a acumulação de sais (provenientes da água e dos fertilizantes) no meio de desenvolvimento das plantas, quando não se adota uma fração de lixiviação. Ressalva-se ainda que o cultivo em substratos tem como importante desvantagem, conforme Milner (2002); a baixa capacidade tampão, o que significa baixa tolerância a erros no manejo da irrigação e da fertirrigação, e exigindo, portanto, monitoramento constante. 


\subsection{Salinidade e citricultura}

Organizando informações, Cadahía (2000) aponta como causas do aumento da salinidade em substratos: a presença de fertilizantes insolúveis, como os de liberação controlada, quando se degradam para produzir nitratos, ou ainda quando liberam sais mediante difusão, em uma quantidade superior às absorvidas ou lixiviadas; a concentração de sais dissolvidos na água de irrigação ou na solução fertilizante, quando superior às quantidades absorvidas pela planta ou perdidas por lixiviação; e a elevada CTC do substrato, com concomitante decomposição ao longo do cultivo, liberando nutrientes. Como forma de atenuar os efeitos da salinidade, o autor recomenda: manter sempre úmido o substrato; jamais aplicar fertilizantes em pó ou soluções fertilizantes com elevada concentração iônica quando o solo estiver seco; e reduzir o estresse das plantas mediante sombreamento e incremento da umidade relativa.

A resposta das plantas à salinidade depende de sua idade, das condições ambientais, das práticas de manejo de cultivo e das características da espécie (ASCE, 1990).

Diversos pesquisadores já atentaram para a necessidade de se investigar os efeitos da irrigação com água salina sobre as frutas cítricas e o meio-ambiente. A despeito de tratar-se de um objeto de estudo identificado desde 1937, quando Oppenheimer fez os primeiros relatos da influência dos sais na citricultura, trabalhos recentes demonstram a importância estratégica de seu aprofundamento para a sustentabilidade dos cultivos em países como Estados Unidos (Zekri \& Parsons, 1992; Romero-Aranda \& Syvertsen, 1996), Israel (Levy et al., 1999), Espanha (Bañuls \& Primo-Millo, 1995; García-Sánchez, 2000), Austrália (Morinaga \& Sykes, 2001; Storey, 1995), Japão (Yang et al., 2002), Turquia (Hepaksov et al., 2002; Can et al., 2002) e Jordânia (Abu-Awwad, 2001). Na maioria destes países, o tema tornase. bastante importante devido às condições climáticas favoráveis à salinização dos solos e também devido à disponibilidade de água salina. No Brasil, pela mesma 
razão, Cruz et al. (2001) estudaram a influência da salinidade sobre o crescimento do limoeiro 'Cravo', justificando seus esforços na presença de áreas salinizadas e potencialmente sujeitas à salinização, encontradas no Nordeste do País. Em quase todos os casos, porém, a salinidade é avaliada mediante aplicações de cloreto de sódio $(\mathrm{NaCl})$ na água de irrigação, em detrimento da utilização das águas salinas encontradas na natureza.

Maas \& Hoffman (1977) definiram que a relação entre salinidade e produção pode ser expressa como uma função de resposta linear negativa em níveis de salinidade acima do limite crítico. Compilando dados de outros pesquisadores, tipicamente obtidos com tratamentos por mais de 2 a 4 anos, com vários níveis de salinidade, Maas (1993) relatou uma salinidade limiar (condutividade elétrica do extrato de saturação) e um declínio (\% de redução da produção por $1 \mathrm{dSm}^{-1}$ aumentado na salinidade acima do limite) de, respectivamente, $1,4 \mathrm{dSm}^{-1}$ e $13 \%$ para citros.

As frutas cítricas são classificadas como sensíveis aos sais (Ayers e Westcot, 1999) devido à toxidez específica do cloro $\left(\mathrm{Cl}^{-}\right)$e/ou do sódio $\left(\mathrm{Na}^{+}\right)$e ao efeito osmótico causado pela alta concentração de sais (Storey \& Walker, 1999). O cloro $\left(\mathrm{Cl}^{*}\right)$ e o sódio $\left(\mathrm{Na}^{+}\right)$são os dois ions tóxicos que podem se acumular nas follhas de frutas cítricas sob condições salinas (Levy et al., 1999), sendo que a habilidade de fruteiras cítricas em se desenvolver em solos salinos está geralmente associada com a 'exclusão" mais do que a 'tolerância' aos íons nas folhas (Storey \& Walker, 1999). Ao termo 'exclusão', entende-se a capacidade dos genótipos em evitar o acúmulo de íons tóxicos, o que é regulado por mecanismos fisiológicos. Por sua vez, a tolerância, conforme Storey \& Walker (1999), refere-se à resistência aos sais já acumulados.

Como demonstrado por Bañuls et al. (1991), a quantidade de íons tóxicos $\left(\mathrm{Na}^{+} \mathrm{e} \mathrm{Cl}^{-}\right)$acumulada pelas plantas cítricas, quando se utiliza água salina, pode ser diminuída pela aplicação de nitrato de cálcio $\left(\mathrm{Ca}\left(\mathrm{NO}_{3}\right)_{2} 2 \mathrm{H}_{2} \mathrm{O}\right)$, o que melhoraria o desenvolvimento das plantas. 
Conforme Storey \& Walker (1999), a literatura mostra que há considerável diversidade na resistência aos sais dentro do gênero Citrus e entre espécies aparentadas, mas que existe também exemplos de inconsistência na classificação de porta-enxertos, como observado por Maas (1993), o que pode ser devido às diferenças nas condições experimentais e também a possíveis causas genéticas.

Em citros, o sistema radicular tem uma influência pronunciada sobre a quantidade acumulada de $\mathrm{Cl}^{-}, \mathrm{Na}^{+}$ou ambos os íons nas folhas de plantas enxertadas e não-enxertadas (Storey \& Walker, 1999). Lloyd et al. (1989) informam que a copa parece ter efeito quando os porta-enxertos são pouco eliminadores dos íons tóxiços.

\subsection{Variedades cítricas estudadas}

Considerando a amplitude de sensibilidade das variedades cítricas à salinidade, tem-se a possibilidade de direcionar a utilização de águas salinas para as combinações de porta-enxerto/copa mais tolerantes, preservando as águas doces para as combinações sensíveis. Identificar combinações tolerantes é a temática de diversos trabalhos visando pomares produtivos em áreas salinizadas (Gallasch \& Dalton, 1989; Lloyd et al., 1990; Nieves et al., 1990; Nieves et al., 1991; Zekri \& Parsons, 1992; Levy \& Shalhevet, 1990; García-Legaz et al., 1993; Bañuls \& PrimoMillo, 1995; Levy et al., 1999). Além disso, a suscetibilidade à salinidade é um importante parâmetro para avaliação de genótipos em programas de melhoramento (Forner \& Forner-Giner, 2002), sendo que, especificamente, já se desenvolve trabalhos de melhoramento de Citrus para a menor suscetibilidade aos sais (Tozlu et al., 2002), partindo do conhecimento que a habilidade dos genótipos em 'excluir' íons de $\mathrm{Cl}^{-}$e Na${ }^{+}$é uma característica hereditária (Sykes, 1992).

Em São Paulo, a produção de mudas cítricas não visa atender casos em que a citricultura é efetivada sob condições salinas. Portanto, a produção de combinações de variedades tolerantes aos sais atenderia tão somente onde houvesse exploração de 
águas salinas e não ao mercado consumidor. Neste sentido, trabalhos precisam ser conduzidos, sobretudo, para avaliar o sucesso da utilização de águas salinas para produção de mudas das variedades requeridas pelo mercado, independente da existência de materiais menos suscetíveis aos efeitos dos sais.

Os principais porta-enxertos utilizados na citricultura brasileira são: limoeiro 'Cravo', limoeiro 'Rugoso', limoeiro 'Volkameriano', laranjeira 'Caipira', tangerineira 'Cleópatra', tangerineira 'Sunki', Poncirus 'Trifoliata', citrumeleiro 'Swingle' e tangelo 'Orlando' (Carvalho, 2001). Já as variedades copa mais importantes para a industrialização de suco concentrado de laranja são (Estanislau et al., 2001): 'Pêra', 'Valência', 'Natal' e 'Hamlin'.

O limoeiro 'Cravo', destacado dentre os demais porta-enxertos pelo alto vigor e tolerância à seca (Carvalho, 2001), é o principal porta-enxerto brasileiro, mas evidências têm sugerido seu relacionamento com a morte súbita dos citros, sendo divulgado que a convivência com mais esta doença pode depender da substituị̧ão desse porta-enxerto por outros não afetados (Müller et al., 2002).

Plantas enxertadas sobre tangerineira 'Cleópatra' e citrumeleiro 'Swingle' não parecem ser afetadas pela morte súbita (Müller et al., 2002), sendo ambos bastante indicados para substituição do 'Cravo', especialmente para pomares livres de estresse hídrico prolongado. Uma importante restrição para o uso do 'Swingle' é sua incompatibilidade com a 'Pêra', principal variedade copa de laranjeira no Brasill. Já a 'Cleópatra' tem como desvantagem proporcionar o início da produção muito tardiamente.

A despeito das inconsistências apontadas por Maas (1993) na classificação de genótipos cítricos em relação à sua sensibilidade aos sais, tem-se reportado constantemente o limoeiro 'Cravo' e a tangerineira 'Cleópatra' como dos menos suscetíveis aos sais (Storey \& Walker, 1999), tanto pela 'exclusão' de íons $\mathrm{Cl}^{-}$ quanto pela de $\mathrm{Na}^{+}$. Por outro lado, a laranjeira trifoliata (Poncirus trifoliata) e seus híbridos, incluindo o citrumeleiro 'Swingle", são considerados inefícientes 
'eliminadores' de $\mathrm{Cl}^{-}$, mas bons 'eliminadores' de $\mathrm{Na}^{+}$em baixa salinidade (Zekri \& Parsons, 1992). 


\section{MATERIAL E MÉTODOS}

\subsection{Localização e caracterização da área experimental}

O experimento foi conduzido no município de Rio Claro - SP, em estufas da empresa Citrograf Mudas ${ }^{9}$ (Figura 1), obedecendo-se a todas as normas exigidas pelo Programa de Certificação de Mudas Cítricas vigente no Estado de São Paulo e respeitando as práticas de manejo da empresa, sem detrimento das interferências necessárias às validações científicas. A empresa está localizada na zona rural de Rio Claro, sendo circunscrita por plantação de eucaliptos, o que lhe distancia de pomares cítricos.

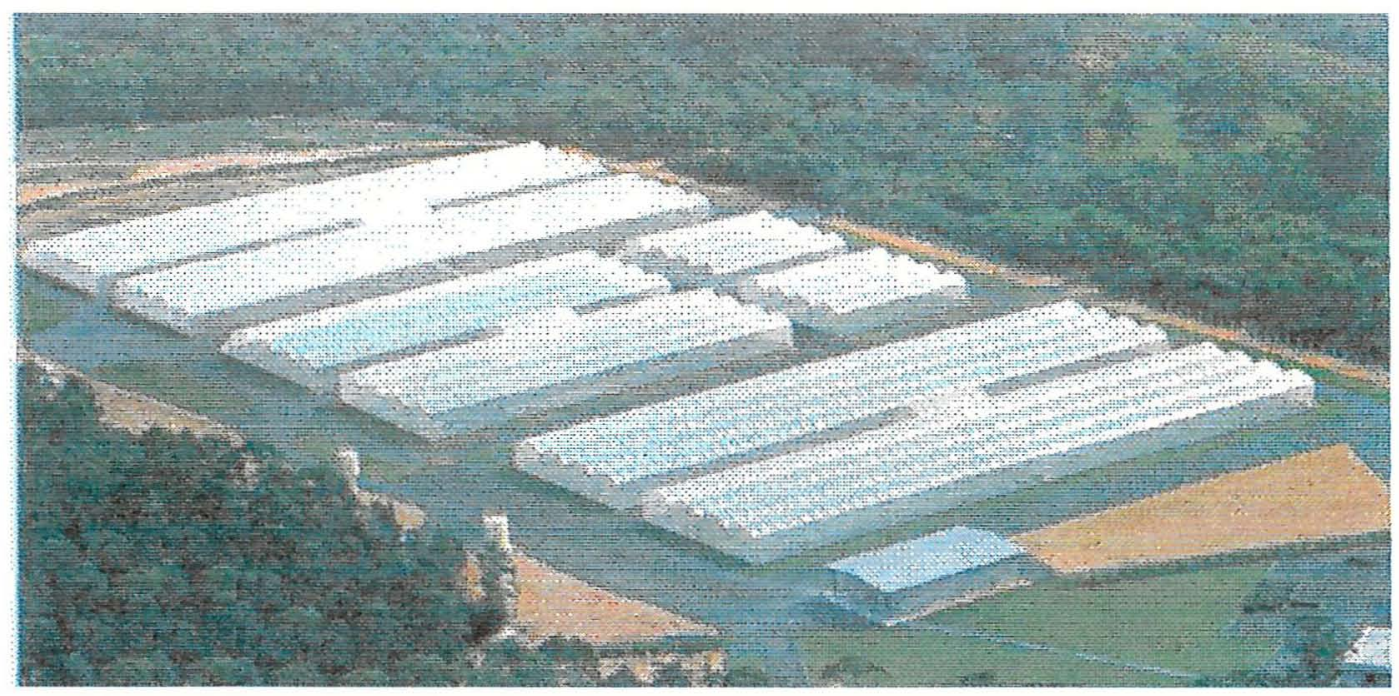

Figura 1 - Vista aérea das estufas da Citrograf Mudas em Rio Claro-SP

\footnotetext{
${ }^{9}$ A Citrograf Mudas é uma empresa tradicional na produção de mudas cítricas, e integrante fundadora da Vivecitrus, Associação Paulista dos Viveiros Certificados de Citros.
} 
A cidade de Rio Claro está situada no Centro-Leste do Estado de São Paulo, entre as coordenadas geográficas $22^{\circ} 05^{\prime}$ e $22^{\circ} 40^{\prime} \mathrm{S}, 47^{\circ} 30^{\prime}$ e $47^{\circ} 55^{\prime} \mathrm{W}$. Segundo Monteiro (1973), o clima da região pode ser considerado tropical com duas estações definidas - Cwa na classificação de Koeppen, ou seja, seca no inverno (w), apresentando mês mais quente com temperatura superior a $22^{\circ} \mathrm{C}$ (a), ou tropical alternadamente seco e úmido, controlado por massas tropicaís e equatoriais, que predominam em mais de $50 \%$ do ano. A temperatura média do mês mais frio varia entre $3^{\circ} \mathrm{C}$ e $18^{\circ} \mathrm{C}$. As temperaturas médias anuais situam-se entre 18,1 e $20,9^{\circ} \mathrm{C}$ (Troppmair, 1992). Os ventos dominantes provêm dos quadrantes S e SE.

A estufa cedida para instalação (Figura 2) dos experimentos tem $2650 \mathrm{~m}^{2}$, é coberta por filme plástico transparente, apresentando laterais protegidas por telas antiafídicas, de malha $1 \mathrm{~mm}^{2}$, levantadas sobre muretas de concreto que se elevam a $0,3 \mathrm{~m}$ do chão. $\mathrm{O}$ acesso à estufa é restrito e resguardado por uma ante-câmara, onde há um pedilúvio. As bancadas são de concreto armado, erguidas a $0,4 \mathrm{~m}$ do solo, tendo a capacidade de comportar 8 mudas ensacoladas em 1,30 m de largura. Os experimentos foram conduzidos no centro de bancadas localizadas no meio da estufa. Deve-se registrar ainda, que a estufa durante todo período experimental, esteve ocupada plenamente, e com plantas transplantadas com mesmo porte e na mesma data das plantas investigadas, estando o experimento protegido do 'efeito oásis'.

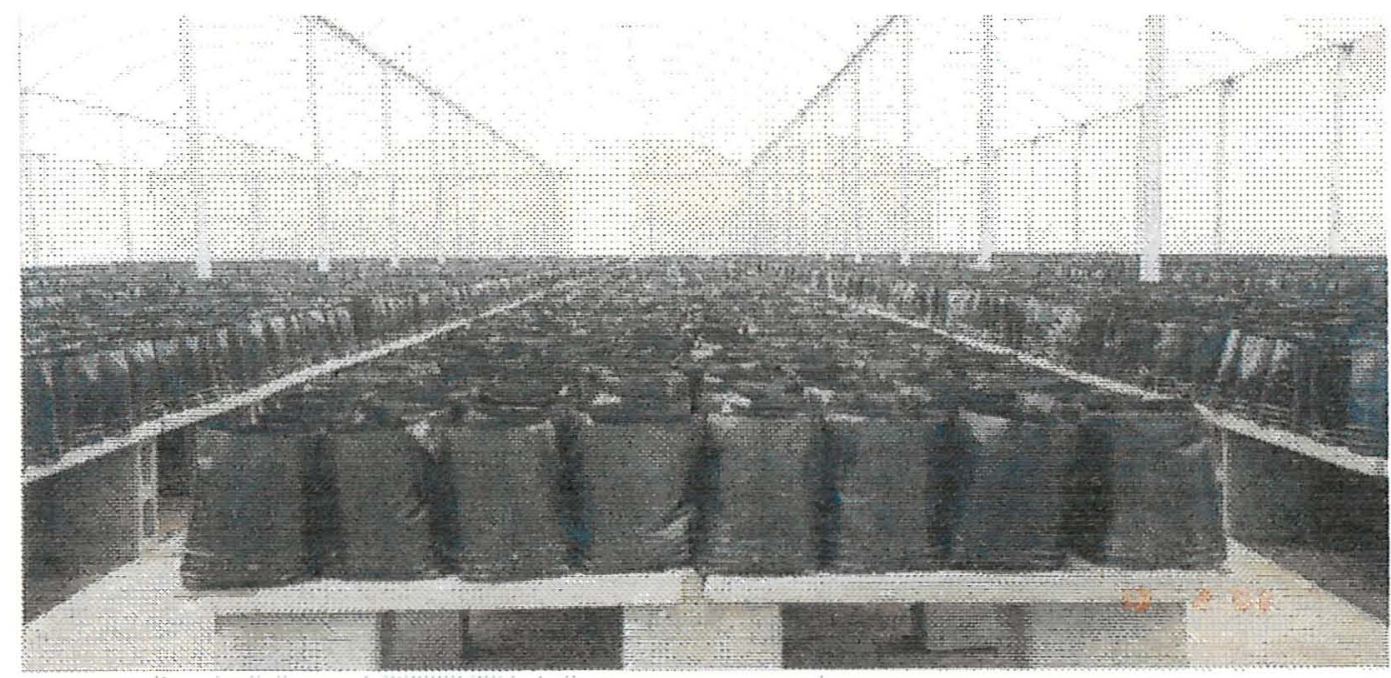

Figura 2 - Vista do interior da estufa utilizada na experimentação 


\subsection{Recurso hídrico explorado}

A água utilizada na unidade de Rio Claro da Citrograf Mudas é de origem subterrânea. Receando ${ }^{10}$ prejuízos ao crescimento das mudas, a empresa adquiriu um equipamento de osmose reversa para dessalinizar a água, obtida de um poço tubular profundo, antes de utilizá-la na irrigação. As análises das águas utilizadas são apresentadas nos Anexos B, C e D.

É possível que a água encontrada seja oriunda do aquitardo Passa Dois, que, conforme DAEE (1988), é constituído de bancos de lamitos, folhetos e calcárioṣ, interpostos entre os aqüíferos Botucatu e Tubarão, exercendo regionalmente um papel passivo quanto à circulação de águas subterrâneas. Nos poços que atravessam o Passa Dois há ocorrência de águas impróprias para o consumo humano e para irrigação, com teores freqüentemente excessivos de sulfatos, cloretos e carbonatos.

\subsection{Meio de cultivo}

Os porta-enxertos destinados ao experimento foram desenvolvidos em tubetes plásticos em formato de tronco de cone (Figura 3), sendo transplantados, em 19/02/2003; para sacolas cilíndricas de polietileno preto ( 25 x $32 \mathrm{~cm}$; Anexo E), com capacidade para $5 \mathrm{~L}$ (Girardi et al., 2001a), as quais foram preenchidas com 2,5 kg de substrato comercial à base de casca de Pinus.

Para adubação do meio de cultivo, utilizou-se fertilizante de liberação lenta na formulação de 22-04-08 com micronutrientes, aplicado na dosagem de 2,46 $\mathrm{kgm}^{-3}$ (Girardi et al., 2001b). Os grânulos do fertilizante foram posicionados na parte superior do meio de cultivo (Figura 4), sendo cobertos por uma camada extra de

\footnotetext{
${ }^{10}$ Considerando a salinidade limiar $\left(\right.$ CEes $\left.=1,4 \mathrm{dS} \mathrm{m}^{-1}\right)$ indicada por Maas $(1993)$ para citros.
} 
substrato, de modo que as sacolas passaram a comportar, em média, 2,80 kg de substrato, à umidade de comercialização do produto.

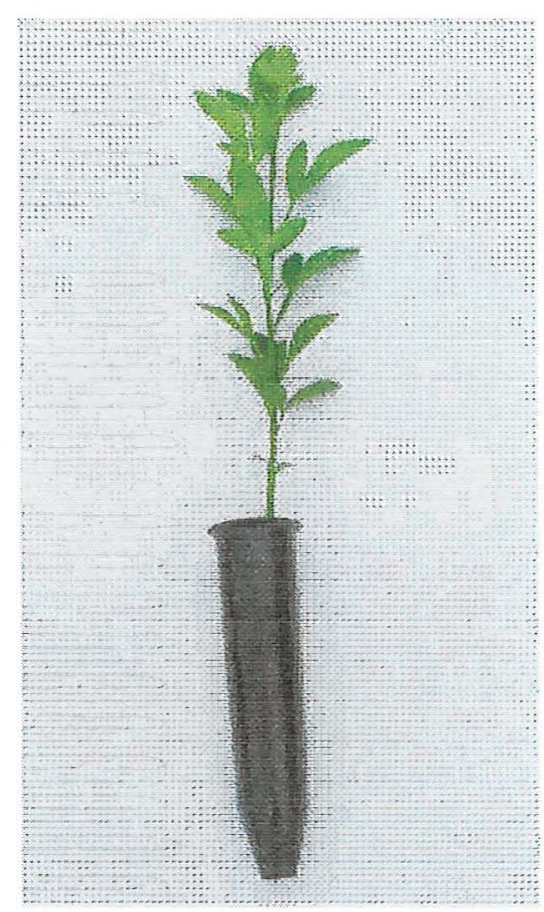

Figura 3 - Plântula de citrumeleiro 'Swingle' em tubete

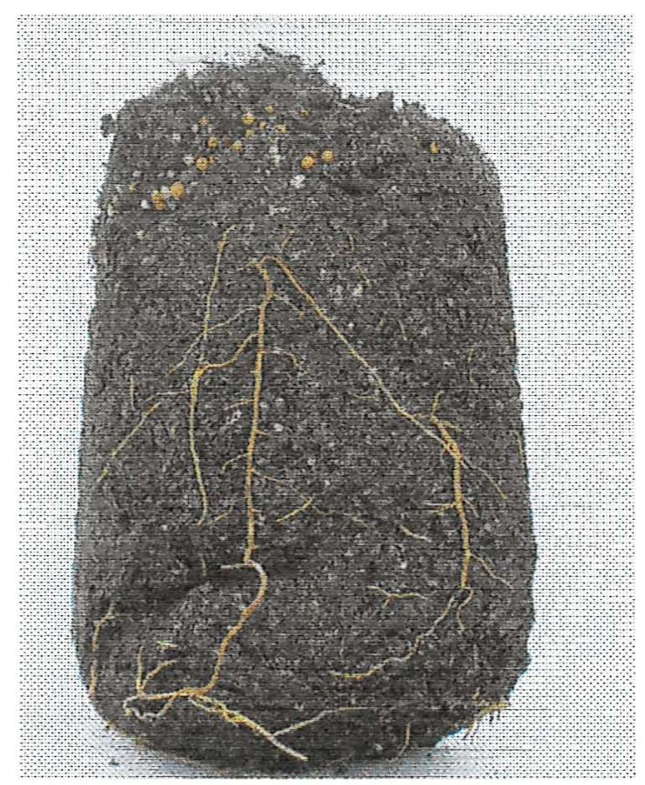

Figura 4 - Detalhe da concentração do fertilizante na parte superior do meio de cultivo 
Conforme dados do fornecedor, o substrato utilizado é composto por cascas de Pinus estabilizadas ( $60 \%$, base volume), vermiculita expandida média ( $30 \%$, base volume), carvão vegetal granulado (10\%, base volume) e NPK com micronutrientes, apresentando densidade absoluta igual a $0,50 \mathrm{~g} \mathrm{~cm}^{-3}$. A umidade de comercialização do produto varia de 50 a 55\% (base peso), sendo a capacidade máxima de retenção de água divulgada de pelo menos $150 \%$ (base peso). A condutividade elétrica (diluição 2:1, substrato: água) especificada é de 1 a $2 \mathrm{dS} \mathrm{m}^{-1}$, estando o $\mathrm{pH}$ garantido entre 5,5 e 6,2. Na Tabela 1 são mostrados os resultados da análise físico-química do substrato, analisado como adubo orgânico. O substrato também foi analisado conforme os procedimentos de rotina para solo, sendo os resultados apresentados na Tabela 2.

O fertilizante de liberação controlada (Figura 5) é formado por grânulos secos de nutrientes, os quais são encapsulados dentro de camadas múltiplas de resina polimérica. A água penetra através da cobertura permeável e dissolve o núcleo de nutrientes. A pressão osmótica resultante dentro do grânulo libera os nutrientes através da cápsula para o meio de cultivo. Segundo o fabricante, a umidade não altera a liberação do produto, sendo exclusivamente a temperatura do meio o fator externo ambiental que a afeta. Diminuindo-se a temperatura do meio, diminui-se a liberação. A longevidade do produto, ao contrário da liberação, é dependente das práticas culturais adotadas e das condições climáticas (temperatura principalmente). À temperatura média de $21,1^{\circ} \mathrm{C}$ no meio de cultivo, a longevidade do produto é garantida por oito a nove meses. A Tabela 3 traz os resultados da análise química do fertilizante. 
Tabela 1. Caracterização físico-química do substrato orgânico*

\begin{tabular}{|c|c|c|}
\hline Determinações & Umidade Natural & Base Seca $\left(110^{\circ} \mathrm{C}\right)$ \\
\hline $\mathrm{pH} \mathrm{em} \mathrm{CaCl}_{2} 0,01 \mathrm{M}$ & 5,8 & - \\
\hline Densidade absoluta & $0,58 \mathrm{~g} \mathrm{~cm}^{-3}$ & - \\
\hline Umidade perdida a $60-65{ }^{\circ} \mathrm{C}$ & $49,41 \%$ & - \\
\hline Umidade perdida entre 65 e $110^{\circ} \mathrm{C}$ & $3,09 \%$ & - \\
\hline Umidade total & $52,50 \%$ & $0,00 \%$ \\
\hline Matéria orgânica total (combustão) & $25,25 \%$ & $53,16 \%$ \\
\hline Matéria orgânica compostável & $23,03 \%$ & $48,48 \%$ \\
\hline Matéria orgânica resistente a compostagem & $2,22 \%$ & $4,67 \%$ \\
\hline Carbono total (orgânico e mineral) & $14,03 \%$ & $29,54 \%$ \\
\hline Carbono orgânico & $12,79 \%$ & $26,93 \%$ \\
\hline Resíduo mineral total & $22,25 \%$ & $46,84 \%$ \\
\hline Resíduo mineral insolúvel & $13,57 \%$ & $28,57 \%$ \\
\hline Resíduo mineral solúvel & $8,68 \%$ & $18,27 \%$ \\
\hline Nitrogênio total & $0,27 \%$ & $0,57 \%$ \\
\hline Fósforo $\left(\mathrm{P}_{2} \mathrm{O}_{5}\right)$ total & $0,32 \%$ & $0,67 \%$ \\
\hline Potássio $\left(\mathrm{K}_{2} \mathrm{O}\right)$ total & $0,14 \%$ & $0,29 \%$ \\
\hline Cálcio $(\mathrm{Ca})$ total & $0,92 \%$ & $1,94 \%$ \\
\hline Magnésio $(\mathrm{Mg})$ total & $0,85 \%$ & $1,79 \%$ \\
\hline Enxofre (S) total & $0,25 \%$ & $0,53 \%$ \\
\hline Relação $\mathrm{C} / \mathrm{N}$ (C total e $\mathrm{N}$ total $)$ & $51 ; 1$ & $51 ; 1$ \\
\hline Relação $\mathrm{C} / \mathrm{N}$ (C orgânico e $\mathrm{N}$ total) & $47 ; 1$ & $47 ; 1$ \\
\hline Cobre $(\mathrm{Cu})$ total & $20 \mathrm{mg} \mathrm{kg}^{-1}$ & $42 \mathrm{mg} \mathrm{kg}^{-1}$ \\
\hline Manganês (Mn) total & $120 \mathrm{mg} \mathrm{kg}^{-1}$ & $253 \mathrm{mg} \mathrm{kg}^{-1}$ \\
\hline Zinco $(\mathrm{Zn})$ total & $53 \mathrm{mg} \mathrm{kg}^{-1}$ & $112 \mathrm{mg} \mathrm{kg}^{-1}$ \\
\hline Ferro $(\mathrm{Fe})$ total & $11.911 \mathrm{mg} \mathrm{kg}^{-1}$ & $25.076 \mathrm{mg} \mathrm{kg}^{-1}$ \\
\hline Boro (B) total & $5 \mathrm{mg} \mathrm{kg}^{-1}$ & $11 \mathrm{mg} \mathrm{kg}^{-1}$ \\
\hline Sódio (Na) total & $225 \mathrm{mg} \mathrm{kg}^{-1}$ & $474 \mathrm{mg} \mathrm{kg}^{-1}$ \\
\hline
\end{tabular}

*Análise realizada no Departamento de Solos e Nutrição de Plantas - ESALQ/USP. 
Tabela 2 . Caracterização química do substrato conforme os procedimentos rotineiros para análise de solo*

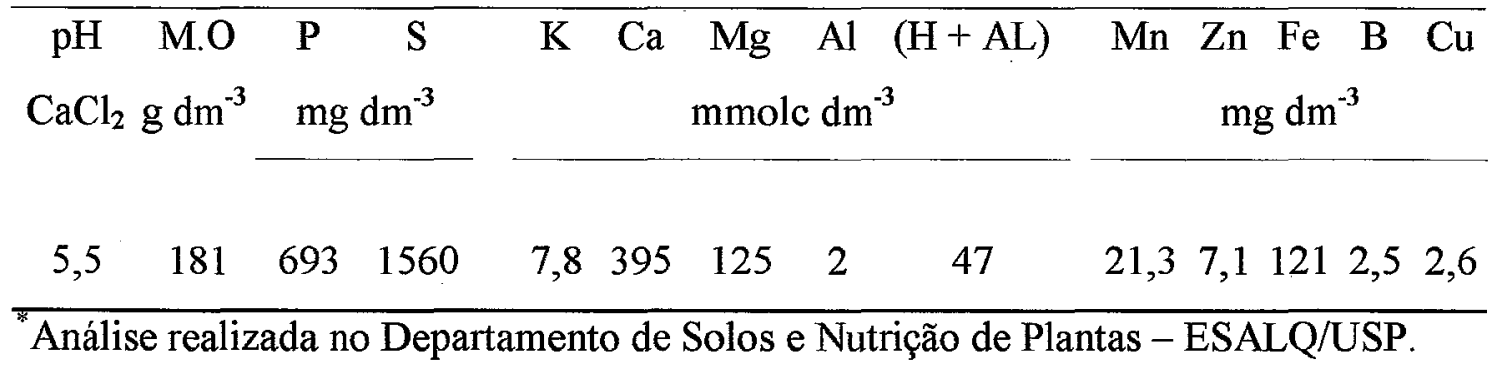

Tabela 3 . Composição química do fertilizante de liberação controlada*

\begin{tabular}{ccc}
\hline Elemento & $\begin{array}{c}\text { Especificações } \\
\text { do fabricante }\end{array}$ & Análise do laboratório \\
\hline Nitrogênio total & $22,00 \%$ & $22,38 \%$ \\
Fósforo $\left(\mathrm{P}_{2} \mathrm{O}_{5}\right.$ em CNA + água) & 4,00 & $4,11 \%$ \\
Potássio ( $\mathrm{K}_{2} 0$ em água) & $8,00 \%$ & $8,66 \%$ \\
Magnésio & $1,00 \%$ & $1,49 \%$ \\
Enxofre & $3,00 \%$ & $4,32 \%$ \\
Ferro & $1,00 \%$ & $1,10 \%$ \\
Manganês & $0,1 \%$ & $0,06 \%$ \\
Cobre & $0,05 \%$ & $0,05 \%$ \\
Zinco & $0,05 \%$ & $0,04 \%$ \\
Boro & $0,02 \%$ & $0,01 \%$ \\
Molibdênio & $0,001 \%$ & $* *$ \\
${ }^{*}$ Análise realizada no Departamento de Solos e Nutrição de Plantas - ESALQ/USP. \\
${ }^{* *}$ Elemento não analisado & &
\end{tabular}




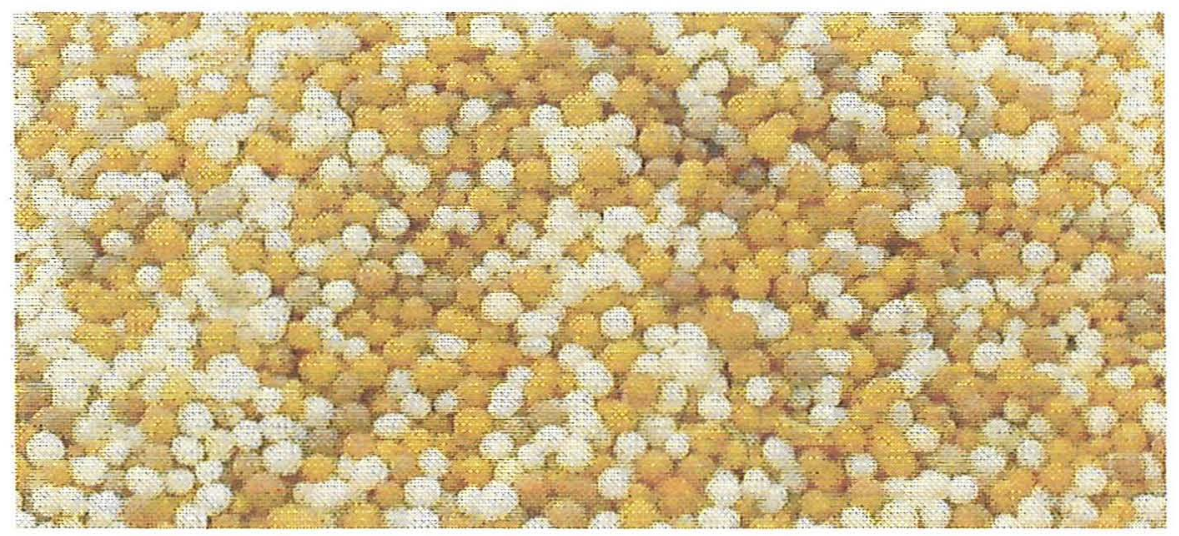

Figura 5 - Grânulos do fertilizante de liberação controlada, utilizado no experimento

No transplantio, somente foram utilizadas mudas previamente selecionadas quanto ao porte (Tabela 4), garantindo-se a uniformidade fenotípica para todos os porta-enxertos avaliados, antes da efetivação dos tratamentos propostos. Atentou-se também para a não utilização de plantas zigóticas, visando a homogeneidade dos genótipos.

As plantas foram desbrotadas freqüentemente para se desenvolver em caule único e, conforme o calendário da empresa e preconização técnica (Graf, 1999), foram efetivadas aplicações preventivas com defensivos e fertilizantes, via foliar. Durante todo o período experimental não foram registrados quaisquer sintomas de deficiência mineral.

Tabela 4 . Altura inicial dos porta-enxertos (27/02/2003) avaliados antes do início da experimentação

\begin{tabular}{cccc}
\hline Porta- enxerto & $\begin{array}{c}\text { Altura média } \\
(\mathrm{cm})\end{array}$ & $\begin{array}{c}\text { Desvio padrão } \\
(\mathrm{cm})\end{array}$ & $\begin{array}{c}\text { Coeficiente de } \\
\text { Variação (\%) }\end{array}$ \\
\hline Limoeiro 'Cravo' & 27,79 & 0,50 & 1,82 \\
Tangerineira 'Cleópatra' & 28,47 & 0,43 & 1,51 \\
Citrumeleiro 'Swingle' & 28,28 & 0,40 & 1,40 \\
\hline
\end{tabular}




\subsection{Tratamentos}

As plantas dos porta-enxertos limoeiro 'Cravo' (Citrus limonia Osbeck), tangerineira 'Cleópatra' (C. reshni Hort. ex Tan.) e citrumeleiro 'Swingle' (C. paradisi Macf. x Poncirus trifoliata [L.] Raf.), após 20 dias de seu transplantio (10/03/2003), foram submetidas por 66 dias (até 15/05/2003) aos seguintes níveis de condutividade elétrica na água de irrigação: 0,$02 ; 1,19 ; 2,11 \mathrm{dS} \mathrm{m}{ }^{-1}$. Avaliou-se, concomitantemente, os efeitos da adição de nitrato de cálcio $\left(\mathrm{Ca}\left(\mathrm{NO}_{3}\right)_{2} \cdot 2 \mathrm{H}_{2} \mathrm{O}\right)$ às águas de irrigação, conforme os tratamentos demonstrados nas Tabelas 5, 6 e 7, e nos quais está fixado em $20 \mathrm{meq} \mathrm{L}^{-1}$ a concentração de nitrato de cálcio (Anexo F).

Tabela 5. Tratamentos aos quais foi submetido o porta-enxerto 'Cleópatra'

\begin{tabular}{ccc}
\hline Tratamento & Tipo de água para irrigação & CEa \\
\hline Testemunha Absoluta (T1) & Água doce & 0,02 \\
Testemunha Relativa (T2) & Água doce com Nitrato de $\mathrm{Ca}^{+2}$ & 2,13 \\
T3 & Água natural & 1,19 \\
T5 & Água natural com Nitrato de Ca & 2,83 \\
T4 & Água residual & 2,11 \\
T6 & Água residual com Nitrato de Ca & 3,66 \\
\hline
\end{tabular}

Tabela 6 . Tratamentos aos quais foi submetido o porta-enxerto 'Cravo'

\begin{tabular}{ccc}
\hline Tratamento & Tipo de água para irrigação & CEa \\
\hline Testemunha Absoluta (T7) & Água doce & 0,02 \\
Testemunha Relativa (T8) & Água doce com Nitrato de Ca ${ }^{+2}$ & 2,13 \\
T9 & Água natural & 1,19 \\
T11 & Água natural com Nitrato de $\mathrm{Ca}^{+2}$ & 2,83 \\
T10 & Água residual & 2,11 \\
T12 & Água residual com Nitrato de $\mathrm{Ca}^{+2}$ & 3,66 \\
\hline
\end{tabular}


Tabela 7. Tratamentos aos quais foi submetido o porta-enxerto 'Swingle'

\begin{tabular}{ccc}
\hline Tratamento & Tipo de água para irrigação & CEa \\
\hline Testemunha Absoluta (T13) & Água doce & 0,02 \\
Testemunha Relativa (T14) & Água doce com Nitrato de $\mathrm{Ca}^{+2}$ & 2,13 \\
T15 & Água natural & 1,19 \\
T17 & Água natural com Nitrato de Ca & 2,83 \\
T16 & Água residual & 2,11 \\
T18 & Água residual com Nitrato de $\mathrm{Ca}^{+2}$ & 3,66 \\
\hline
\end{tabular}

A condutividade elétrica de $1,19 \mathrm{dS} \mathrm{m}^{-1}$ é naturalmente encontrada na água subterrânea explorada na área experimental (Apêndice 1, Anexo B) e, conforme o processo de osmose reversa (Figura 6), utilizada para dessalinizá-la, produz-se a água com condutividade elétrica de $0,02 \mathrm{dS} \mathrm{m}^{-1}$ (Apêndice 1, Anexo C). Como subproduto do processo de dessalinização, tem-se a água residual com concentração iônica majorada, e de condutividade elétrica de $2,11 \mathrm{dS} \mathrm{m}^{-1}$ (Apêndice 1, Anexo D). A adição de nitrato de cálcio às águas dessalinizada, natural e residual resulta nos seguintes níveis de condutividade elétrica: $2,13 \mathrm{dS} \mathrm{m}^{-1}, 2,83 \mathrm{dS} \mathrm{m}^{-1}$ e; 3,66 $\mathrm{dS} \mathrm{m}^{-1}$, respectivamente (Apêndice 2). 


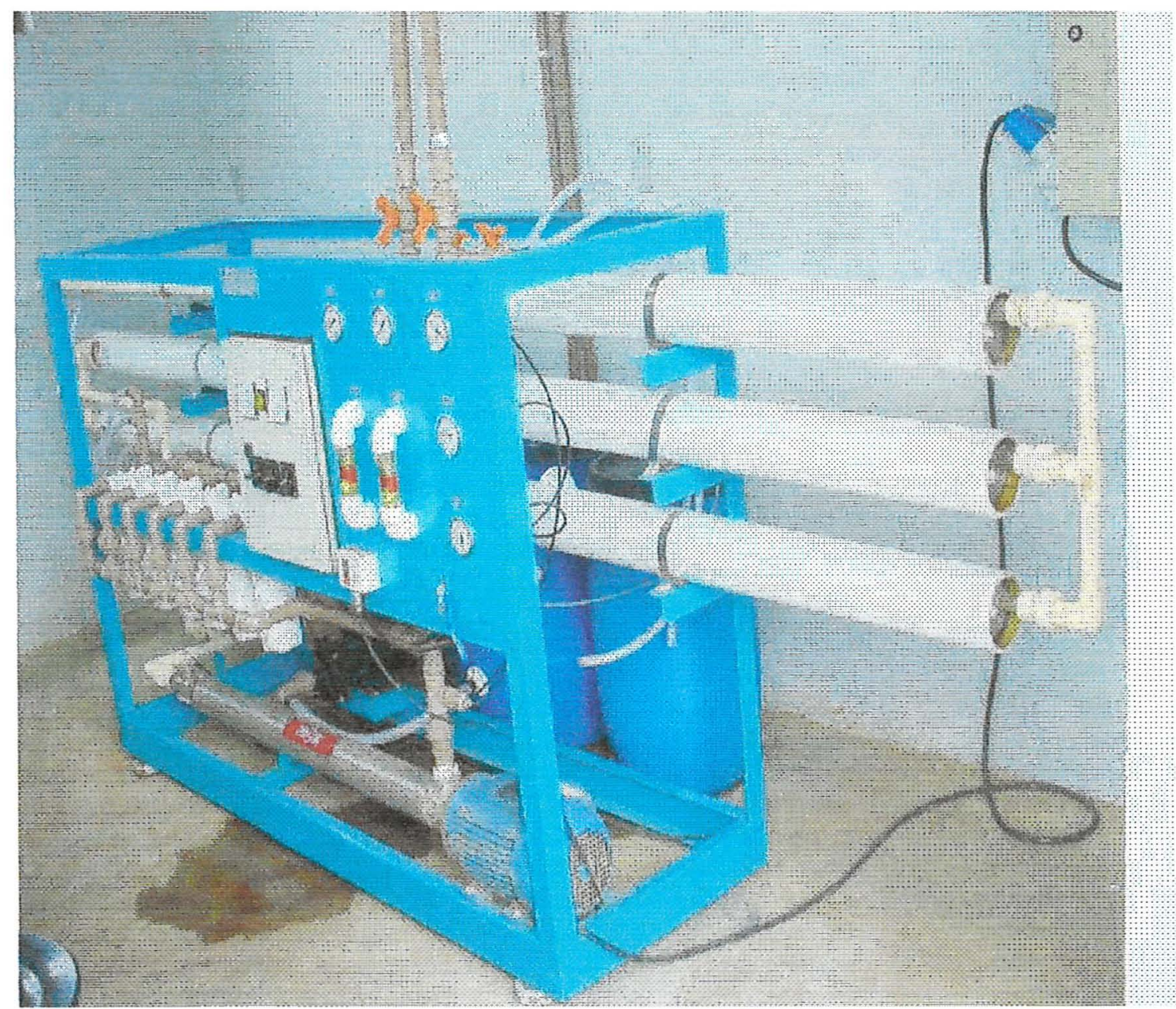

Figura 6 . Equipamento de osmose reversa utilizado para dessalinização da água natural.

\subsection{Delineamento estatístico adotado}

O experimento foi conduzido em blocos casualizados, com 18 tratamentos arranjados em esquema fatorial de $3 \times 3 \times 2$ (porta-enxertos $\times$ qualidade química da água $\mathrm{x}$ aplicação de nitrato de cálcio), com 6 repetições. Cada parcela foi representada por 8 mudas ensacoladas. As plantas a serem avaliadas destrutiva e periodicamente foram sorteadas entre as plantas úteis de cada parcela. Visando preservar as características de stand comercial, em seus lugares foram repostas 
plantas do mesmo porte. A análise estatística foi efetuada pelo programa SAS, sendo a comparação das médias realizada pelo teste de Tukey a 5\% quando a razão $\mathrm{F}$ de Snedeor acusava possível significância a 5\%. A Tabela 8 apresenta o esquema da análise de variância.

Tabela 8 . Esquema da análise de variância

\begin{tabular}{cc}
\hline Causas da variação & $\mathbf{N}^{\mathbf{0}}$ de graus de liberdade (G.L.) \\
\hline Blocos & 5 \\
Tratamentos & 17 \\
\hline Nitrato de Cálcio $\left(\mathrm{Ca}^{+2}\right)$ & 1 \\
*Qualidade química da água (CEa) & 2 \\
Porta-enxerto (P.E.) & 2 \\
$\mathrm{Ca}^{+2}$ x CEa & 2 \\
$\mathrm{Ca}^{+2}$ x P.E. & 2 \\
$\mathrm{CEa}$ x P.E. & 4 \\
$\mathrm{Ca}^{+2}$ x CEa x P.E. & 4 \\
Resíduo & 85 \\
Total & $\mathbf{1 0 7}$
\end{tabular}

*O parâmetro adotado para expressão da qualidade da água foi a condutividade elétrica da água de irrigação (CEa).

\subsection{Controle da irrigação}

O controle da irrigação foi efetuado para cada tipo de porta-enxerto separadamente, mediante a pesagem (Figura 7) das sacolas para o cálculo da evapotranspiração diária, utilizando-se para tanto apenas plantas irrigadas com água dessalinizada (Testemunha Absoluta). O volume de irrigação calculado, inicialmente com a eq. (1), que considera uma fração de lixiviação de $20 \%$, e, posteriormente, 
com a eq. (2), na qual a fração de lixiviação não é computada, foi medido em recipientes, previamente calibrados mediante utilização de uma proveta, e entạo entornado parcimoniosamente no substrato de cultivo, praticamente sem contato com as folhas. A velocidade da operação foi controlada pelo volume de irrigação e também pela umidade atual do substrato, que se mostrou hidrofóbico quando seco, requerendo neste caso mais parcimônia.

$$
\mathrm{VI}=\frac{(\mathrm{Cc}-\mathrm{Pa})}{(1-\mathrm{FL})}
$$

$\mathrm{VI}=\mathrm{Cc}-\mathrm{Pa}$

em que:

$\mathrm{VI}=$ volume de irrigação, $\mathrm{mL}$;

$\mathrm{Cc}=$ peso da sacola com substrato na 'capacidade de container', $\mathrm{g}$;

$\mathrm{Pa}=$ peso atual da sacola antes da irrigação, $\mathrm{g}$;

$\mathrm{FL}=$ fração de lixiviação, decimal.

A transformação do volume aplicado em lâmina de irrigação foi efetuada mediante a eq. (3), considerando a área determinada conforme Anexo E.

$$
\mathrm{LI}=\frac{\mathrm{VI}}{\mathrm{A}}
$$

em que:

LI = lâmina de irrigação, mm;

$\mathrm{VI}=$ volume de irrigação, $\mathrm{L}$;

$\mathrm{A}=$ área da superficie do substrato na sacola, $\mathrm{m}^{2}$. 
Adaptou-se nos recipientes de cultivo, um sistema de coleta para a água drenada, consistindo de um saco plástico transparente, cujo orifício de descarga era vedado dobrando-se o próprio plástico e segurando as dobras com pregador (Figura 8). Em um dos seis blocos, avaliava-se o volume drenado por porta-enxerto, o que permitiu aferir as taxas de lixiviação usando a eq. (4).

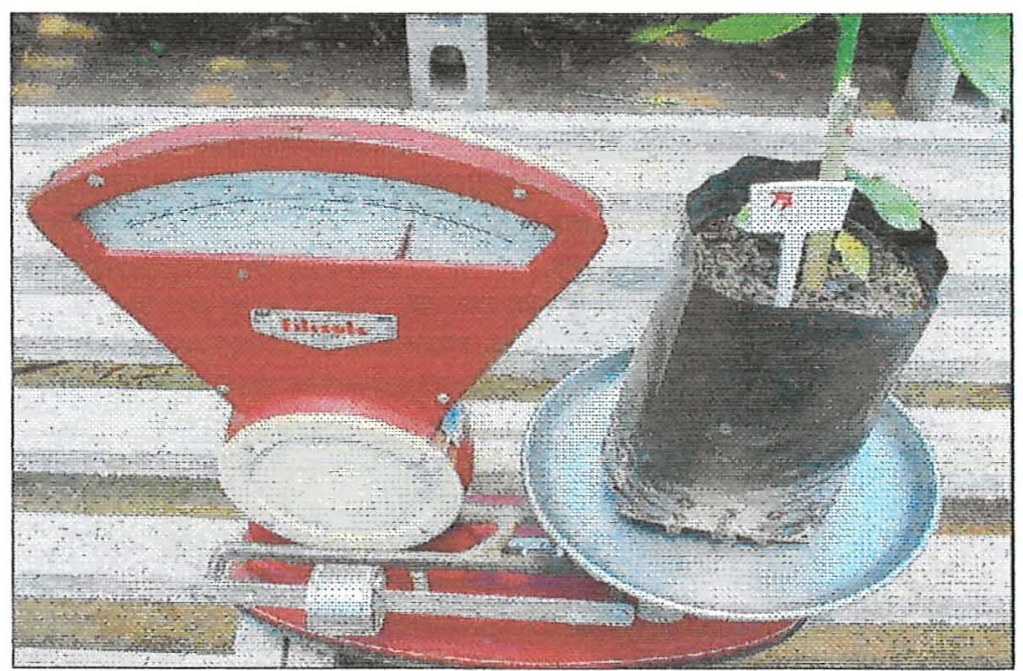

Figura 7 - Balança utilizada para pesagem das mudas

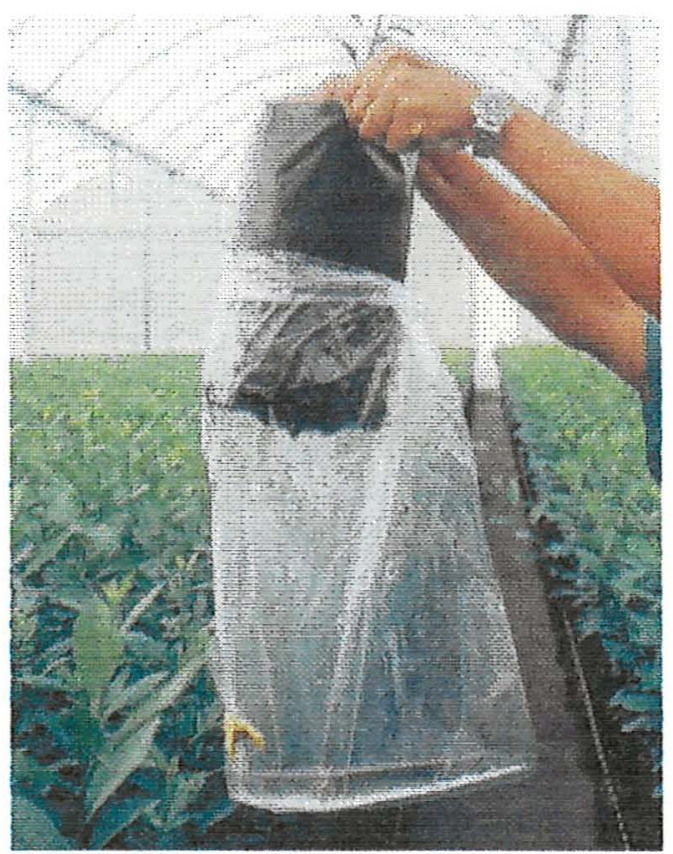

Figura 8 - Sistema de coleta para água drenada 
$\mathrm{Pp}=\frac{\mathrm{Vd}}{\mathrm{VI}} \times 100$

em que:

$\mathrm{Pp}=$ taxa de lixiviação, \%;

$\mathrm{VI}=$ volume de irrigação, $\mathrm{mL}$;

$\mathrm{Vd}=$ volume drenado, $\mathrm{mL}$.

\subsection{Monitoramento da salinização}

A salinização do substrato foi monitorada mediante análise do lixiviado obtido no aparato de coleta da drenagem. Periodicamente, foram coletadas amostras das repetições, as quais constituíram amostras compostas para cada tratamento, sendo a análise de condutividade elétrica efetuada em aparelho portátil.

Ao final do período experimental, avaliou-se a salinização do substrato mediante a medição da condutividade elétrica, do $\mathrm{pH}$ e das concentrações de cálcio, de cloro e de sódio do extrato de saturação, também utilizando amostras compoștas de todas as repetições para cada tratamento.

A obtenção do extrato de saturação seguiu a metodologia de Warncke (1990), com algumas modificações: em aproximadamente $500 \mathrm{~cm}^{3}$ de substrato, adicionou-se água destilada, efetuando a homogeneização da mistura com espátula, até se observar o ponto de saturação (distinguido em função do brilho superficial e do deslizamento da pasta sobre espátula). Esperou-se cerca de uma hora para conferir a estabilidade da umidade e a necessidade de adição de mais água ou substrato. Após três horas de repouso, a pasta foi transferida para um funil de Buckner contendo papel filtro e adaptado a um frasco coletor que era submetido a vácuo. Aplicada a sucção por 30 minutos, obteve-se cerca de $70 \mathrm{~mL}$ de extrato. $\mathrm{O}$ pH e a condutividade 
elétrica foram medidos diretamente nas soluções. As concentrações de cálcio e de sódio foram avaliados mediante espectrofotometria de absorção atômica, enquanto o cloreto mediante o método orgentométrico.

\subsection{Avaliação do desenvolvimento das mudas}

O experimento foi avaliado em três épocas, caracterizadas em DAT (dias após o transplantio): 41 DAT, 63 DAT e 85 DAT, as quais correspondem, respectivamente a 22,44 e 66 dias de condicionamento aos tratamentos. Durante

estas épocas foram mensurados, mediante amostragem simples nos blocos, os seguintes parâmetros: altura da muda, diâmetro do caule, número de folhas, área foliar, massa seca das folhas, massa seca do caule, massa seca da parte aérea, massa seca das raízes, massa seca total e relação raiz/parte aérea.

Tão logo coletadas as plantas, media-se sua altura com uma régua graduada, considerando o nível do substrato e a ponta do caule como referências. Em seguida, mensurava-se o diâmetro do caule em paquímetro digital (precisão de $0,01 \mathrm{~mm}$ ), a um cm do nível do substrato. As folhas eram então destacadas e levadas rapidamente a um integrador de área para medição de sua área foliar. Procedia-se a lavagem dạs raízes de todas as plantas, oportunidade em que se coletavam amostras de substrato para análíse. Após obtenção de valor constante, em estufa a $60{ }^{\circ} \mathrm{C}$, obtinha-se as massas da matéria seca das folhas, do caule, da parte aérea, do sistema radicular e da planta como um todo.

Ao final do experimento também foram avaliados, a partir de amostragem composta, as concentrações foliares de nitrogênio, fósforo, potássio, cálcio, magnésio, enxofre, cloreto e sódio, seguindo as seguintes metodologias:

Sódio: após extração por digestão nitro-perclórica, este elemento foi determinado por espectrofotometria de absorção atômica; 
Potássio, Cálcio e Magnésio: após extração por digestão nitro-perclórica, estes elementos foram determinados por espectrofotometria de absorção atômica, sendo o Ca e Mg em solução de lantânio 0,1\%;

Enxofre: após extração por digestão nitro-perclórica, o enxofre orgânico fọi oxidado a sulfato e precipitado pela adição de cloreto de bário. Logo em seguida, determinado colorimetricamente e/ou turbidimetricamente;

Fósforo: após extração por digestão nitro-perclórica, o fósforo total foi determinado colorimetricamente pelo método do vanatado-molibdato de amônio;

Nitrogênio: determinado por destilação, pelo método Kjeldahl. O presente método determina o nitrogênio amoniacal total. $\mathrm{O}$ nitrogênio orgânico é convertido a sulfato de amônio, por meio da oxidação da matéria orgânica em $\mathrm{H}_{2} \mathrm{SO}_{4}$. Em meio alcalino, a amônia é destilada e recebida em solução de ácido bórico, com indicadores apropriados, sendo depois titulada com solução de ácido sulfúrico. 


\section{RESULTADOS E DISCUSSÃO}

\subsection{Lâminas aplicadas e taxas de lixiviação}

Analisando-se a Figura 9 e o Apêndice 3, verifica-se que as mudas de limoeiro 'Cravo' demandaram maiores lâminas de irrigação que as de tangerineira 'Cleópatra' e as de citrumeleiro 'Swingle', sendo que para estes dois últimos portaenxertos se repôs praticamente o mesmo montante de água requerida ao longo do período experimental. As lâminas diárias repostas ao limoeiro 'Cravo', à tangerineira 'Cleópatra' e ao citrumeleiro 'Swingle' foram, em média, respectivamente: 5,27 mm $\mathrm{d}^{-1} ; 3,49 \mathrm{~mm} \mathrm{~d}^{-1}$ e $3,43 \mathrm{~mm} \mathrm{~d}^{-1}$.

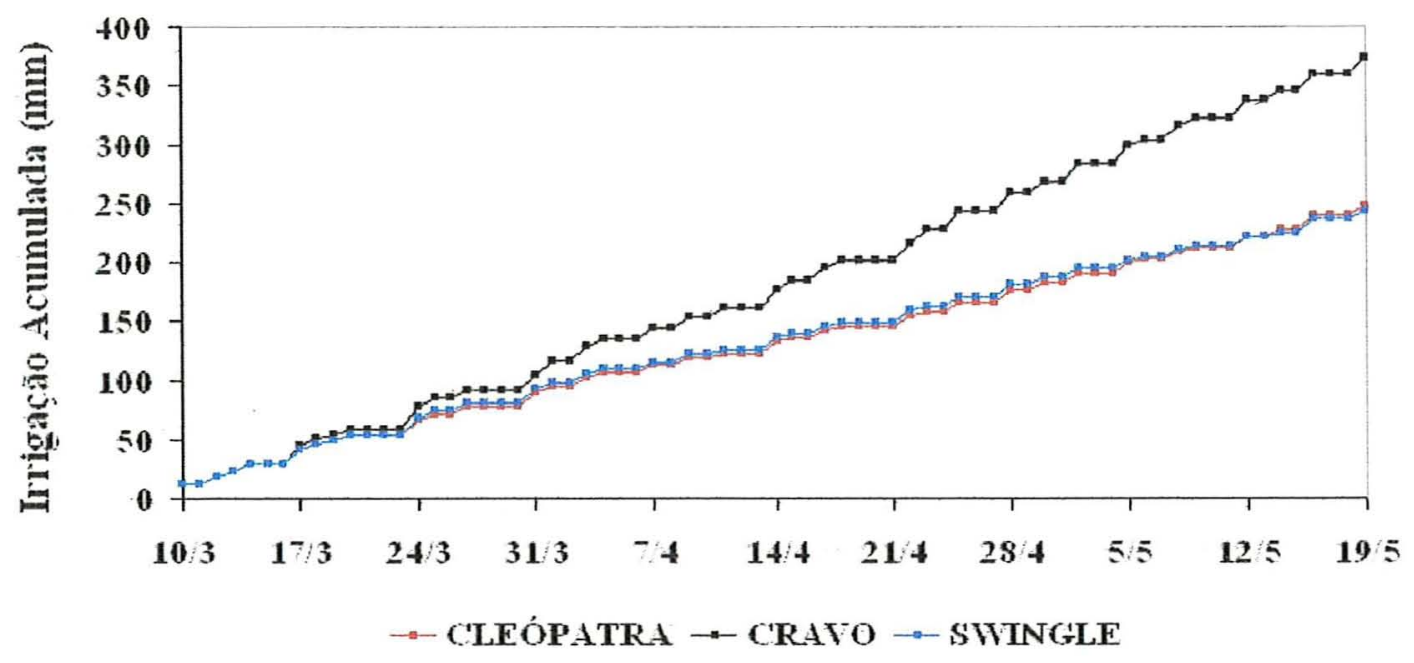

Figura 9 - Lâmina de irrigação acumulada por porta-enxerto ao longo do período experimental 
A maior necessidade de reposição de água para as plantas do limoeiro 'Cravo' está em concordância com a observação de Medina (1977), que verificou maior condutância hidráulica do sistema radicular desse porta-enxerto, em relação a 'Cleópatra', 'Troyer' e Poncirus trifoliata, cultivados em vasos e sem deficiência hídrica, condição para qual também registrou maior assimilação diária de $\mathrm{CO}^{2}$ pelo 'Cravo', alcançado neste parâmetro apenas por Poncirus trifoliata.

Inicialmente, procurou-se aplicar uma fração de lixiviação de $20 \%$ a cada irrigação (Anexo G), entretanto a lâmina assim corrigida proporcionava drenagem acima do previsto. Tentou-se ainda controlar a irrigação por meio de um balanço hídrico, assumindo como lâmina de irrigação o consumo registrado para o dia anterior, entretanto, continuou-se observando elevadas taxas de lixiviação. Neste sentido, manteve-se o controle de irrigação efetuado pela pesagem dos recipientes em função da 'capacidade de container', sem impor a aplicação de uma fração de lixiviação.

Os dados de lixiviação apresentados na Figura 10 e no Apêndice 4 são inerentes à drenagem natural, decorrente da metodologia supracitada e sintetizada na eq. (2), ou seja, mesmo quando se calculava a lâmina de irrigação a ser aplicada sem incluir uma fração de lixiviação, verificava-se que a mesma ocorria. Isto se deve provavelmente ao fato da velocidade de percolação ser superior à velocidade de absorção de água no substrato utilizado. Sinaliza-se esta possibilidade pela verificação de que, quando seco, o substrato mostrou-se hidrofóbico na camada superior, sendo registrado que as maiores taxas de lixiviação advieram das maiores lâminas aplicadas, ou seja, após as maiores perdas de água no meio. Durante o período experimental, as taxas médias de lixiviação para os tratamentos com os porta-enxertos limoeiro 'Cravo', citrumeleiro 'Swingle' e tangerineira 'Cleópatra' foram, respectivamente: $25,23 \% ; 26,10 \%$; e $28,41 \%$. 


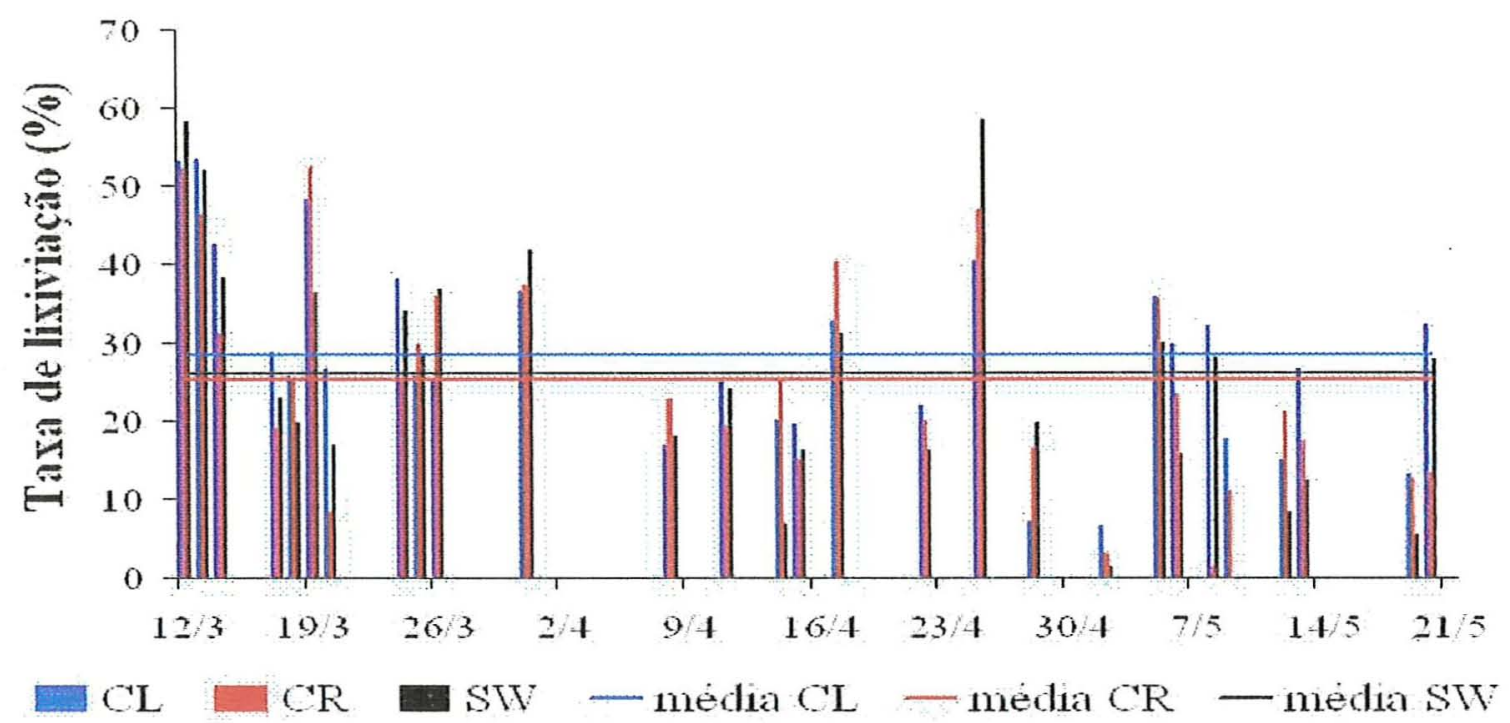

Figura 10 - Taxas de lixiviação diárias e médias registradas para os porta-enxertos

'Cleópatra' (CL), 'Cravo' (CR) e 'Swingle' (SW) no experimento

Considerando o registro das maiores taxas de lixiviação sempre após as maiores perdas de água no substrato, o que se verificava após os finais de semana, quando não se irrigava, deve-se ponderar pela utilização de irrigações mais freqüentes, visando manter uma umidade mínima no substrato anterior à exteriorização de sua característica hidrofóbica, a qual pode: dificultar sua rehidratação, aumentar o desperdício de água, diminuir a oferta da lâmina requerida pelas plantas e reduzir a qualidade da lixiviação de sais, sendo a tendência normal da água aplicada sobre o substrato seco movimentar-se lateralmente ou por caminhos preferenciais verticalmente, o que impede a lavagem dos sais por todo o perfil do meio de cultivo.

Sendo as irrigações efetuadas quase que diariamente, o secamento do substrato, verificado após os finais de semana ou eventuais dias consecutivos sem irrigação, logo era revertido, não prejudicando o manejo. Diferentemente, Gervásio (2003), trabalhando com outro substrato à base de casca de Pinus, para produção de mudas de cafeeiro em tubete, teve dificuldades sérias, inclusive com mortalidade de plantas, em conseqüência da hidrofobia criada, quando se absteve da recomendação 
do fabricante de efetuar um pré-umedecimento do substrato, para o enchimento dos tubętes.

Segundo Francescato (1995), maiores freqüências de irrigação são necessárias para manutenção de maiores valores de umidade em substratos à base de casca de Pinus. O autor observou maiores oscilações na umidade dos substratos irrigados com menor freqüência de irrigação, o que difícultou a absorção de água, principalmente em substratos com maior granulometria, com reflexo significativo no crescimento das mudas de citros.

\subsection{Evolução da salinidade ao longo do período experimental}

Observa-se nas Figuras 11, 12 e 13, e no Apêndice 5, os valores de CE medidos na água de lixiviação. Pode-se verificar que a salinização do substrato foi crescente ao longo do tempo para quase todos os tratamentos, sendo que a adição de nitrato de cálcio elevou consideravelmente a salinidade do meio. De maneira geral, para as testemunhas absolutas (T1, T7 e T13) observaram-se os menores valores de condutividade elétrica da água drenada, seguindo-se os valores proporcionados pela irrigação com a água natural sem nitrato de cálcio (T3, T9 e T15) e com a água residual sem nitrato de cálcio (T4, T10 e T 16).

Particularmente para o limoeiro 'Cravo', verifica-se nitidamente a diminuição da salinidade do substrato para as águas dessalinizada (T7) e natural (T9), o que pode ser explicado pelo maior consumo de nutrientes em atendimento ao destacado desenvolvimento deste porta-enxerto, como apontado pela sua maior necessidade de água (Figura 9), sabendo-se que o acúmulo de matéria vegetal é proporcional à transpiração. Por outro lado, e pela mesma razão, também se registraram elevados valores indicativos de salinização para o limoeiro 'Cravo', especialmente para os tratamentos com nitrato de cálcio (T8, T11 e T12), já que o acúmulo de sais é proporcional à quantidade de água aplicada. Também foram 
verificados elevados valores de $\mathrm{CE}$ nos tratamentos em que o nitrato de cálcio foi aplicado sobre a tangerineira 'Cleópatra' (T2, T5 e T6) e sobre o citrumeleiro 'Swingle' (T14, T17 e T18).

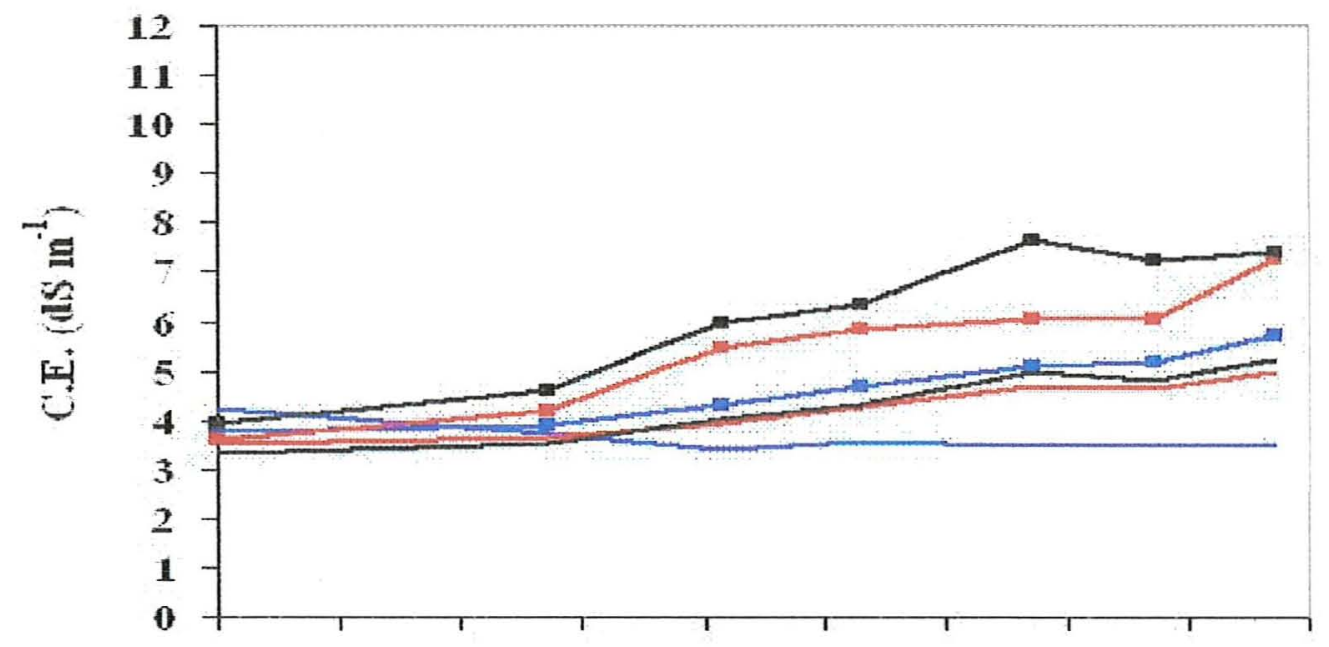

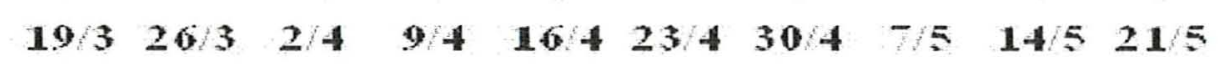

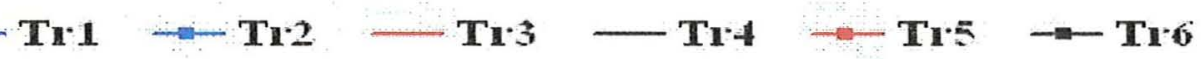

Figura 11 - Condutividade elétrica da água lixiviada para os tratamentos com o porta-enxerto tangerineira 'Cleópatra' ao longo do experimento

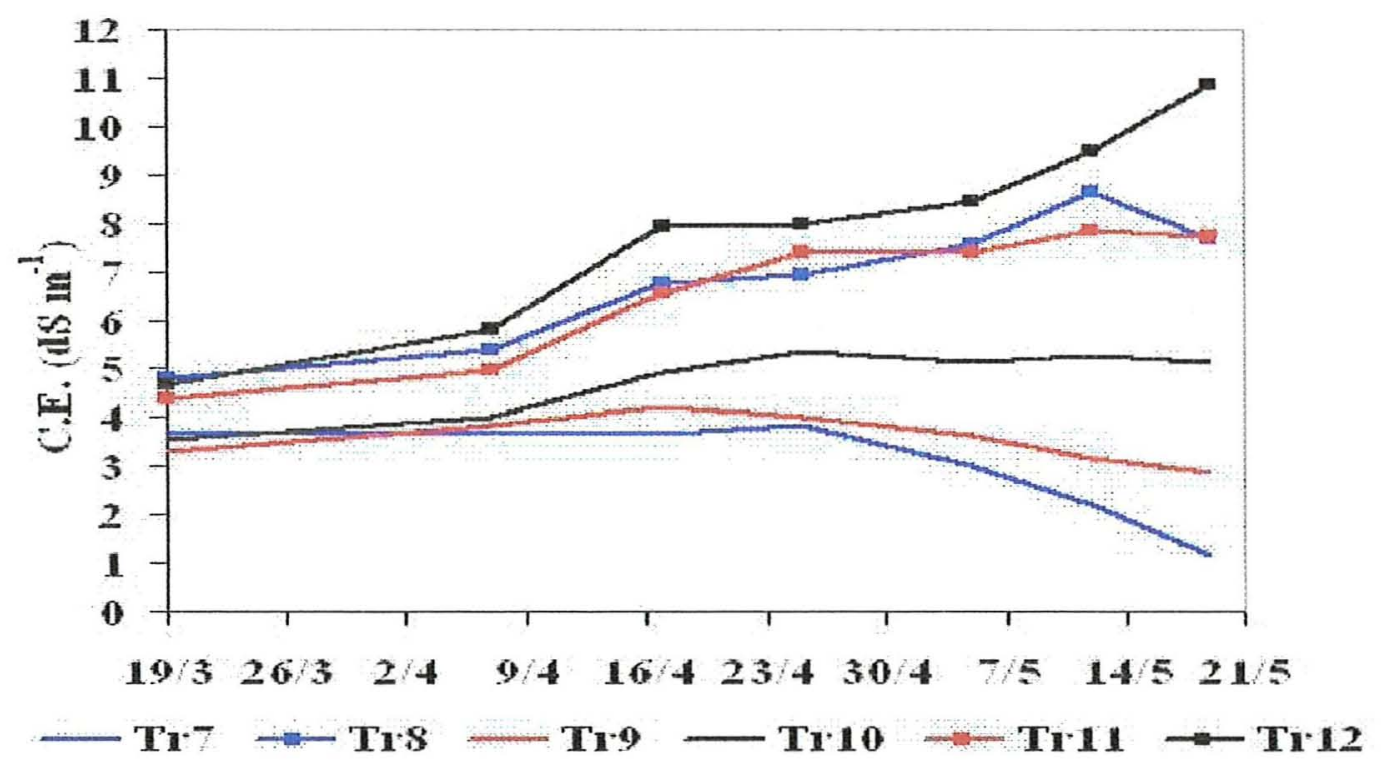

Figura 12 - Condutividade elétrica da água lixiviada para os tratamentos com o porta-enxerto limoeiro 'Cravo' ao longo do experimento 


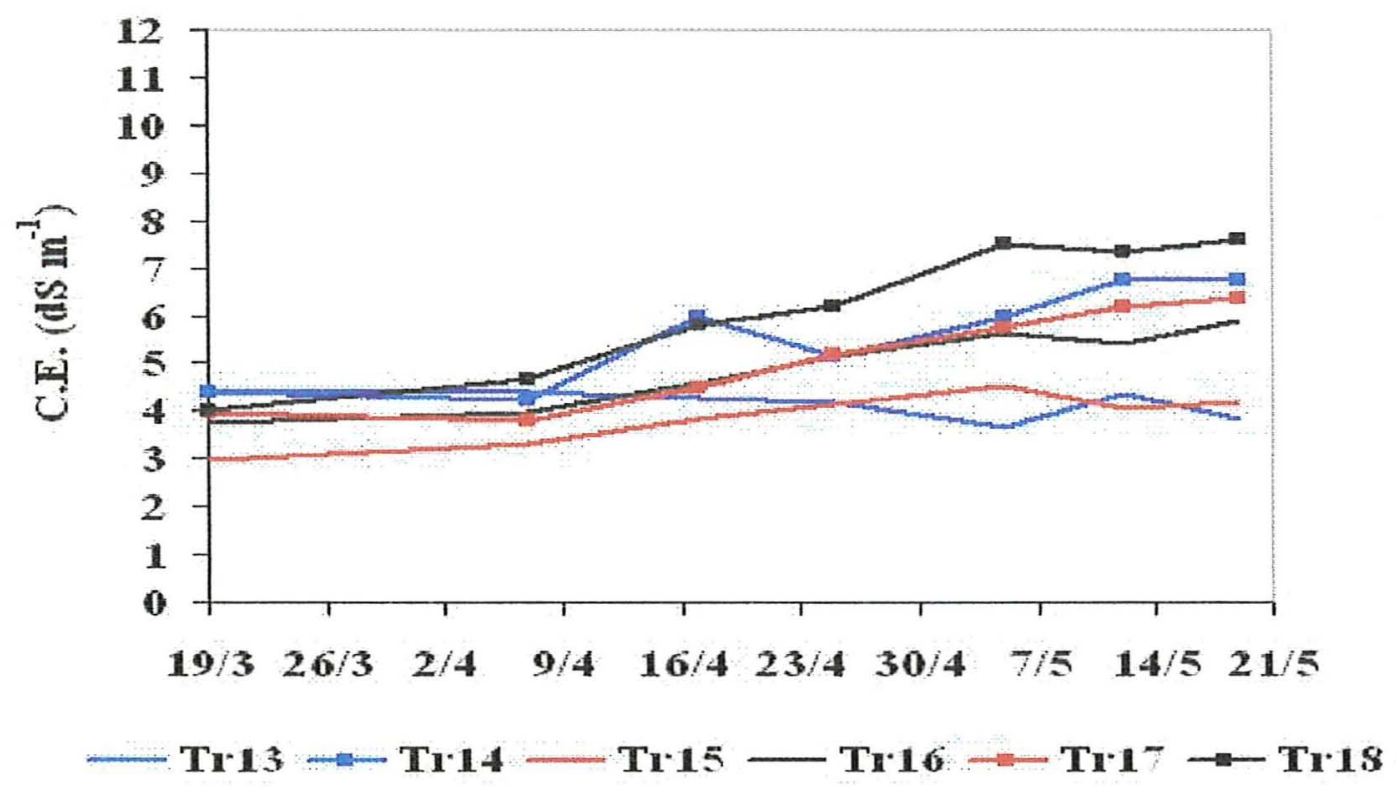

Figura 13 - Condutividade elétrica da água lixiviada para os tratamentos com o porta-enxerto citrumeleiro 'Swingle' ao longo do experimento

Os valores de condutividade elétrica do extrato de saturação do substrato (Tabela 9) foram maiores que os valores de condutividade elétrica das respectivas águas de irrigação (Tabelas 5, 6 e 7). Por outro lado, foram menores que os indicados na água de drenagem (Figura 11, 12 e 13, e Apêndice 5), ainda que a tendência observada entre os tratamentos tenha sido semelhante. Este resultado é comumente observado em vários experimentos em que se aplicam frações de lixiviação e, em particular para o experimento em questão, reforçado pelo fato de que as cascas de Pinus têm baixa capacidade de retenção iônica (CTC de $55 \mathrm{meq} 100 \mathrm{~g}^{-1}$, Martínez, 2002). Deste modo, as taxas de lixiviação aplicadas assegurariam a utilização de águas moderadamente salinas e reforçam o uso de adubação de liberação lenta ou do parcelamento múltiplo em caso de adubação convencional, em se mantendo as condições do estudo.

Analisando-se a Tabela 9, observa-se que as águas natural e residual implicam em considerável aumento nos teores de $\mathrm{Na}^{+} \mathrm{e} \mathrm{Cl}^{-}$no extrato de saturação, para todos os porta-enxertos avaliados. A adição de nitrato de cálcio resultou em 
aumento nos teores de $\mathrm{Ca}^{+2}$ e $\mathrm{Na}^{+}$no extrato, sinalizando a menor adsorção e o deslocamento do $\mathrm{Na}^{+}$pelo $\mathrm{Ca}^{+2}$ para a solução do meio. Sobre o teor de $\mathrm{Cl}^{-}$, o nitrato de cálcío promoveu um comportamento variável, ainda que sua diminuição tenha sido mais freqüente ( $67 \%$ dos casos).

Tabela 9 . Resultado da análise do extrato de saturação do substrato, por tratamento, realizada ao final do experimento ${ }^{*}$

\begin{tabular}{|c|c|c|c|c|c|}
\hline Tratamento & $\begin{array}{l}\mathrm{Na} \\
-\cdots \\
\end{array}$ & $\begin{array}{c}\mathrm{Ca} \\
-\mathrm{mg} \mathrm{L}\end{array}$ & Cl & $\begin{array}{c}\text { CEes } \\
\mathrm{dS}^{-1}\end{array}$ & pH \\
\hline \multirow[t]{2}{*}{ Origem $* *$} & 51 & 228,5 & 59,4 & 1,8 & 6,9 \\
\hline & --- & rineira ' & $a^{\prime}---$ & ------ & \\
\hline $\mathrm{T} 1$ & 81 & 281,5 & 57,3 & 2,5 & 6,5 \\
\hline $\mathrm{T} 2$ & 91 & 410 & 54,1 & 4,0 & 6,3 \\
\hline T3 & 194 & 301 & 222,8 & 3,1 & 6,3 \\
\hline T4 & 320 & 265 & 364,5 & 3,2 & 6,6 \\
\hline T5 & 216 & 366 & 196,8 & 4,0 & 6,6 \\
\hline \multirow[t]{2}{*}{ T6 } & 372 & 370 & 382,2 & 4,1 & 6,5 \\
\hline & & moeiro & - & ----- & \\
\hline $\mathrm{T} 7$ & 91 & 270 & 66,6 & 2,0 & 6,6 \\
\hline $\mathrm{T} 8$ & 97 & 428,5 & 63,5 & 4,0 & 6,3 \\
\hline T9 & 344 & 245 & 359,3 & 3,1 & 7 \\
\hline $\mathrm{T} 10$ & 582 & 290,5 & 707,1 & 4,0 & 6,9 \\
\hline T11 & 352 & 430 & 289,5 & 4,5 & 6,6 \\
\hline \multirow[t]{2}{*}{$\mathrm{T} 12$} & 504 & 418 & 504 & 5,0 & 6,5 \\
\hline & & rumelei & gle'--- & ----- & \\
\hline $\mathrm{T} 13$ & 74 & 269,5 & 59,4 & 2,6 & 6,9 \\
\hline T14 & 116 & 341,5 & 97,9 & 3,5 & 6,9 \\
\hline T15 & 192 & 273 & 222,8 & 3,0 & 7 \\
\hline T16 & 296 & 262,5 & 413,4 & 3,2 & 7 \\
\hline T17 & 228 & 379,5 & 246,8 & 4,0 & 6,9 \\
\hline T18 & 320 & 375,5 & 347,8 & 4,3 & 6,2 \\
\hline
\end{tabular}

* Análise efetuada no Laboratório de Ecologia Aplicada da ESALQ/USP.

** Referente ao substrato amostrado no dia do preenchimento das sacolas, antes da aplicação adubação de liberação controlada. 
O limite máximo de cloreto permissível para o limoeiro 'Cravo' e para a tangerineira 'Cleópatra' é de $888 \mathrm{mg} \mathrm{L}^{-1}$, medido no extrato de saturação. Para o citrumeleiro 'Swingle' este limite é de $355 \mathrm{mg} \mathrm{L}^{-1}$ (Ayers \& Westcot, 1999). Os dados apresentados na Tabela 9 indicam que este limite foi superado apenas no substrato do Tratamento 16, referente ao citrumeleiro 'Swingle' irrigado com água residual sem nitrato de cálcio. Registra-se ainda que a água residual, não corrigida com o nitrato de cálcio, proporcionou acúmulo de cloreto em níveis próximos dos limites citados, à exceção de sua submissão ao porta-enxerto 'Cleópatra' (T4).

A transferência de íons do substrato para a água perdida por percolação também foi observada por Francescato (1995) e por Boaventura (2003). O primeiro autor, ao concluir pela utilização de irrigações mais freqüentes, com decorrente esgotamento dos íons provenientes de adubos de liberação controlada, julgou ter de associa-las à complementação nutricional para produção de mudas de porta-enxertos cítricos em tubetes. Já Boaventura (2003), observou altas concentrações de nutrientes no lixiviado coletado de sacolas cultivadas com mudas enxertadas, devido à rápida difusão dos nutrientes do adubo de liberação controlada.

\subsection{Parâmetros de avaliação do desenvolvimento}

Inicialmente é pertinente discutir o crescimento em função das condições de contorno, igualitárias para todos os tratamentos. Os dados das testemunhas absolutas de cada porta-enxerto permitem inferir se as plantas estudadas cresceram normalmente, na independência da salinidade. Tomou-se como referência para contraste o trabalho de Boaventura (2003), selecionado dentre outros por ser efetuado também sob ambiente protegido e com os mesmos tipos de recipiente e de substrato, e com mesma dose e formulação do adubo de liberação controlada. 
Enquanto no presente trabalho, as plantas testemunhas absolutas do limoeiro 'Cravo' poderiam ser enxertadas com $85 \mathrm{DAT}^{11}$, apresentando em média $104 \mathrm{~cm}$ de altura, $7,39 \mathrm{~mm}$ de diâmetro e um acúmulo de matéria seca total de $21,20 \mathrm{~g}$, as do citrumeleiro 'Swingle', na mesma data, mediam em média $76,67 \mathrm{~cm}$ de altura, 7,96 $\mathrm{mm}$ de diâmetro, acumulando $14,56 \mathrm{~g}$ de matéria seca total. As plantas de limoeiro 'Cravo' de Boaventura (2003) foram enxertadas menos precocemente, aos 100 DAT, apresentando $104 \mathrm{~cm}$ de altura, 7,6 $\mathrm{mm}$ de diâmetro e acúmulo de matéria seca total de $24,5 \mathrm{~g}$, enquanto as do citrumeleiro, à mesma data, tinham altura de $91 \mathrm{~cm}$, diâmetro de $8,08 \mathrm{~mm}$ e matéria seca acumulada de $17,70 \mathrm{~g}$.

Descontando as idades e o porte inicial das plantas no transplantio, e ainda as especificidades climáticas e culturais em cada trabalho, pode-se afirmar que as plantas do limoeiro 'Cravo' e do citrumeleiro 'Swingle' do presente experimento cresceram normalmente.

Para certificar a normalidade do crescimento da tangerineira 'Cleópatra', tomam-se os resultados da Tabela 10, que mostram o crescimento em altura dos três porta-enxertos aqui avaliados, quando submetidos ao manejo cotidiano da empresa, pelo qual o fornecimento de água é realizado via mangueira, e portanto, sem controle da lâmina aplicada. As plantas 'irrigadas" deste modo estavam dispostas em bancada vizinha ao experimento, distribuindo-se exatamente conforme o sorteio aleatório para o delineamento experimental. Observa-se que em altura, as plantas do experimento cresceram tanto quanto as 'supridas' pela empresa, à exceção do limoeiro 'Cravo', visivelmente mais desenvolvido no experimento que fora dele, provavelmente devido à aplicação insuficiente de água via mangueira para satisfazer sua demanda. Os crescimentos da tangerineira 'Cleópatra' e do citrumeleiro 'Swingle', distintos entre si, mas indiferenciados para dentro e fora do experimento, indicam que sua demanda hídrica foi atendida pela aplicação via mangueira, confirmando também que a

\footnotetext{
${ }^{11}$ Foram enxertadas posteriormente, aos 89 DAT.
} 
demanda de ambos se aproxima, quando conduzidos em recipientes de volume limitado.

Tabela 10. Alturas médias dos porta-enxertos* $(\mathrm{cm})$ produzidos conforme o manejo da empresa em comparação com os produzidos no experimento

\begin{tabular}{ccc}
\hline PORTA-ENXERTO & $\begin{array}{c}\text { Altura das plantas } \\
\text { manejadas pela Empresa }\end{array}$ & $\begin{array}{c}\text { Altura das plantas } \\
\text { manejadas Experimento }\end{array}$ \\
\hline Tangerineira 'Cleópatra' & 88,10 & 89,17 \\
Limoeiro 'Cravo' & 84,70 & 110,50 \\
Citrumeleiro 'Swingle' & 79,00 & 75,58 \\
\hline
\end{tabular}

*Valores médios para 216 plantas

**Referentes às testemunhas absolutas

As análises de variância realizadas para os parâmetros de avaliação do desenvolvimento, nas três épocas de amostragem, revelam que as interações duplas e tripla não foram significativas (Apêndices 6, 7 e 8). Assim, as médias foram avaliadas separadamente para os três fatores de variação, quais sejam, tipo de portaenxerto, qualidade da água e adição de nitrato de cálcio.

As Tabelas 11, 12 e 13 e os Apêndices 6, 7 e 8 apresentam os valores médios obtidos para alguns parâmetros de avaliação do desenvolvimento das mudas, nas três épocas de amostragem: 41, 63 e 85 dias após o transplantio (DAT). De maneira geral, somente foram causas de variação signifícativa o tipo de porta-enxerto e a presença de nitrato de cálcio na água de irrigação. O tipo de água utilizado não levou a contrastes significantes entre os tratamentos, à exceção da análise do diâmetro do caule, que acusou diferença estatística na segunda avaliação, distinguindo as águas dessalinizada e natural da água residual:

O maior desenvolvimento das plantas de limoeiro 'Cravo', seguido pelas de citrumeleiro 'Swingle' e por último pelas de tangerineira 'Cleópatra', ao final do período experimental (Tabela 12), também foi reportado por Mourão Filho et al. 
(1998), para a maioria dos substratos que estudaram. Mattos et al. (1988) e Pompeu Jr. (1991) também relatam o menor vigor da tangerineira 'Cleópatra' em relação aos outros porta-enxertos.

Observa-se ainda nas Tabelas 11 e 12 que a aplicação corretiva de nitrato de cálcio às águas de irrigação não contribuiu para o desenvolvimento das mudas, atuando, pelo contrário, negativamente no crescimento inicial do sistema radicular e no engrossamento do caule, o que pode ser reflexo da contribuição desta aplicação para a elevação dos níveis de salinização no substrato (Tabela 9).

Tabela 11 . Médias de valores* tomados aos 41 DAT para: a altura do porta-enxerto (ALT), o diâmetro do porta-enxerto (D), a matéria seca das raízes (MSR), a matéria seca da parte aérea (MSPA), a matéria seca total (MST) e a relação de massas secas das raízes e da parte aérea (R/PA)

\begin{tabular}{ccccccc}
\hline FATOR & ALT (cm) & D (mm) & MS R $(\mathrm{g})$ & MS PA $(\mathrm{g})$ & MS T $(\mathrm{g})$ & R/PA \\
\hline Porta-enxerto & & & & & & \\
'Cleópátra' & $59 \mathrm{~b}$ & $3,99 \mathrm{c}$ & $1,27 \mathrm{c}$ & $3,49 \mathrm{c}$ & $4,76 \mathrm{c}$ & $0,36 \mathrm{a}$ \\
'Cravo' & $65 \mathrm{a}$ & $5,75 \mathrm{~b}$ & $2,01 \mathrm{a}$ & $5,84 \mathrm{a}$ & $7,85 \mathrm{a}$ & $0,35 \mathrm{a}$ \\
'Swingle' & $60 \mathrm{~b}$ & $6,29 \mathrm{a}$ & $1,59 \mathrm{~b}$ & $4,32 \mathrm{~b}$ & $5,91 \mathrm{~b}$ & $0,37 \mathrm{a}$ \\
Nitrato de Ca & & & & & & \\
Sem Nitrato & $61 \mathrm{a}$ & $5,37 \mathrm{a}$ & $1,69 \mathrm{a}$ & $4,6 \mathrm{a}$ & $6,29 \mathrm{a}$ & $0,37 \mathrm{a}$ \\
Com Nitrato & $62 \mathrm{a}$ & $5,32 \mathrm{~b}$ & $1,56 \mathrm{~b}$ & $4,5 \mathrm{a}$ & $6,05 \mathrm{~b}$ & $0,35 \mathrm{~b}$ \\
Tipo de água & & & & & & \\
Dessalinizada & $62 \mathrm{a}$ & $5,39 \mathrm{a}$ & $1,64 \mathrm{a}$ & $4,52 \mathrm{a}$ & $6,16 \mathrm{a}$ & $0,37 \mathrm{a}$ \\
Natural & $62 \mathrm{a}$ & $5,36 \mathrm{a}$ & $1,61 \mathrm{a}$ & $4,54 \mathrm{a}$ & $6,14 \mathrm{a}$ & $0,36 \mathrm{a}$ \\
Residual & $61 \mathrm{a}$ & $5,28 \mathrm{a}$ & $1,63 \mathrm{a}$ & $4,59 \mathrm{a}$ & $6,22 \mathrm{a}$ & $0,36 \mathrm{a}$ \\
\hline
\end{tabular}

*Médias seguidas pelas mesmas letras nas colunas não diferem significativamente entre si ao nível de 5\% pelo teste de Tukey 
Tabela 12 . Médias de valores* tomados aos 63 DAT para: a altura do porta-enxerto (ALT), o diâmetro do porta-enxerto (D), a matéria seca das raízes (MSR), a matéria seca da parte aérea (MSPA), a matéria seca total (MST) e a relação de massas secas das raízes e da parte aérea (R/PA)

\begin{tabular}{ccccccc}
\hline FATOR & ALT $(\mathrm{cm})$ & D $(\mathrm{mm})$ & MS R $(\mathrm{g})$ & MS PA $(\mathrm{g})$ & MS T $(\mathrm{g})$ & R/PA \\
\hline $\begin{array}{c}\text { Porta-enxerto } \\
\text { 'Cleópátra' }\end{array}$ & $74 \mathrm{~b}$ & $4,16 \mathrm{c}$ & $1,73 \mathrm{c}$ & $6,08 \mathrm{c}$ & $7,81 \mathrm{c}$ & $0,28 \mathrm{c}$ \\
'Cravo' & $84 \mathrm{a}$ & $6,54 \mathrm{~b}$ & $3,49 \mathrm{a}$ & $11,38 \mathrm{a}$ & $14,87 \mathrm{a}$ & $0,31 \mathrm{~b}$ \\
'Swingle' & $70 \mathrm{c}$ & $6,84 \mathrm{a}$ & $2,56 \mathrm{~b}$ & $7,56 \mathrm{~b}$ & $10,11 \mathrm{~b}$ & $0,34 \mathrm{a}$ \\
$\begin{array}{c}\text { Nitrato de Ca }{ }^{+2} \\
\text { Sem Nitrato }\end{array}$ & $76 \mathrm{a}$ & $5,94 \mathrm{a}$ & $2,62 \mathrm{a}$ & $8,39 \mathrm{a}$ & $11,01 \mathrm{a}$ & $0,31 \mathrm{a}$ \\
Com Nitrato & $76 \mathrm{a}$ & $5,75 \mathrm{~b}$ & $2,56 \mathrm{a}$ & $8,29 \mathrm{a}$ & $10,86 \mathrm{a}$ & $0,31 \mathrm{a}$ \\
Tipo de água & & & & & & \\
Dessalinizada & $75 \mathrm{a}$ & $5,93 \mathrm{a}$ & $2,65 \mathrm{a}$ & $8,43 \mathrm{a}$ & $11,08 \mathrm{a}$ & $0,31 \mathrm{a}$ \\
Natural & $78 \mathrm{a}$ & $5,92 \mathrm{a}$ & $2,64 \mathrm{a}$ & $\mathbf{8 , 5 4 a}$ & $11,18 \mathrm{a}$ & $0,31 \mathrm{a}$ \\
Residual & $75 \mathrm{a}$ & $5,69 \mathrm{~b}$ & $2,49 \mathrm{a}$ & $\mathbf{8 , 0 5 a}$ & $10,54 \mathrm{a}$ & $0,31 \mathrm{a}$ \\
\hline
\end{tabular}

"Médias seguidas pelas mesmas letras nas colunas não diferem significativamente entre si ao nível de $5 \%$ pelo teste de Tukey

Tabela 13. Médias de valores* tomados aos 85 DAT para: a área foliar (AF), a altura do porta-enxerto (ALT), o diâmetro (D), a matéria seca das raízes (MSR), a matéria seca da parte aérea (MSPA), a matéria seca total (MST) e a relação de massas secas das raízes e da parte aérea (R/PA)

\begin{tabular}{cccccccc}
\hline FATOR & AF (cm2) & ALT $(\mathrm{cm})$ & D (mm) & MS R (g) & MSPA (g) & MST (g) & R/PA \\
\hline Porta-enxerto & & & & & & & \\
'Cleópátra' & $639 \mathrm{~b}$ & $84 \mathrm{~b}$ & $4,51 \mathrm{c}$ & $2,09 \mathrm{c}$ & $8,14 \mathrm{c}$ & $10,23 \mathrm{c}$ & $0,26 \mathrm{c}$ \\
'Cravo' & $1205 \mathrm{a}$ & $108 \mathrm{a}$ & $7,38 \mathrm{~b}$ & $5,15 \mathrm{a}$ & $17,63 \mathrm{a}$ & $22,79 \mathrm{a}$ & $0,29 \mathrm{~b}$ \\
'Swingle' & $536 \mathrm{c}$ & $76 \mathrm{c}$ & $7,66 \mathrm{a}$ & $3,62 \mathrm{~b}$ & $10,45 \mathrm{~b}$ & $14,07 \mathrm{~b}$ & $0,35 \mathrm{a}$ \\
$\begin{array}{c}\text { Nitrato de Ca } \\
\text { Sem Nitrato }\end{array}$ & $799 \mathrm{a}$ & $90 \mathrm{a}$ & $6,63 \mathrm{a}$ & $3,66 \mathrm{a}$ & $12,01 \mathrm{a}$ & $15,66 \mathrm{a}$ & $0,3 \mathrm{a}$ \\
Com Nitrato & $788 \mathrm{a}$ & $89 \mathrm{a}$ & $6,41 \mathrm{a}$ & $3,58 \mathrm{a}$ & $12,14 \mathrm{a}$ & $15,73 \mathrm{a}$ & $0,29 \mathrm{~b}$ \\
Tipo de água & & & & & & & \\
Dessalinizada & $798 \mathrm{a}$ & $89 \mathrm{a}$ & $6,63 \mathrm{a}$ & $3,73 \mathrm{a}$ & $12,16 \mathrm{a}$ & $15,89 \mathrm{a}$ & $0,31 \mathrm{a}$ \\
Natural & $808 \mathrm{a}$ & $90 \mathrm{a}$ & $6,49 \mathrm{a}$ & $3,65 \mathrm{a}$ & $12,38 \mathrm{a}$ & $16,03 \mathrm{a}$ & $0,29 \mathrm{a}$ \\
Residual & $775 \mathrm{a}$ & $89 \mathrm{a}$ & $6,42 \mathrm{a}$ & $3,48 \mathrm{a}$ & $11,69 \mathrm{a}$ & $15,17 \mathrm{a}$ & $0,3 \mathrm{a}$ \\
\hline
\end{tabular}

*Médias seguidas pelas mesmas letras nas colunas não diferem significativamente entre si ao nível de $5 \%$ pelo teste de Tukey. 
Considerando que o limite para a condutividade elétrica no extrato de saturação é de $1,4 \mathrm{dS} \mathrm{m}^{-1}$, referenciado à produção de frutos, conforme Maas (1993), e observando os valores registrados no presente trabalho, pode-se sinalizar que para a produção dos porta-enxertos estudados, após o transplantio, é possível se trabalhar com maiores níveis de salinidade no meio, em relação ao nível limiar preconizado para árvores safreiras. Ainda que a produtividade de frutos possa ser um parâmetro mais sensível ao estresse salino que os parâmetros utilizados para avaliar a performance das mudas, o que explicaria a ausência de prejuízos ao crescimento das mudas sob os níveis de salinidade observados, é mais provável que o curto período necessário ao alcance do ponto de enxertia (85 dias após o transplantio e 66 dias de exposição às águas) tenha restringido efeitos negativos.

Além disso, tem-se que ressalvar que mesmo para as testemunhas absolutas foram registrados valores de condutividade elétrica (Tabela 9) superiores à limiar, demonstrando que a salinidade observada era, em parte, oriunda dos componentes do meio de cultivo. Comparando a salinidade das testemunhas absolutas com a do substrato antes da fertilização com o adubo de liberação lenta (Tabela 9), observa-se que o substrato já apresenta originalmente uma condutividade elétrica superior à limiar, sendo elevada posteriormente com a presença do fertilizante no meio de cultivo, a despeito da garantia de uma lenta liberação de íons.

Atentando-se ainda para os níveis de cloreto e de sódio relevantemente mais baixos nos extratos das testemunhas absolutas e no substrato não fertilizado com $o$ adubo de liberação controlada (Tabela 9), entende-se que a salinização registrada nestes e nos demais tratamentos, é sim em parte decorrente de íons não tóxicos, oriundos do enriquecimento do substrato customizado à Citrograf Mudas (Tabelas 1 e 2) e também oriundos do adubo de liberação controlada. Neste caso, a extrapolação da salinidade limiar sem prejuízos ao crescimento das plantas possivelmente se deve à maior tolerância da cultura à salinidade quando esta é provocada por íons nạo tóxicos, fato este já descrito por pesquisadores para outras espécies. Para a cultura do pimentão, por exemplo, a salinidade limiar no extrato de saturação indicada por 
Maas \& Hoffman (1977) e por Medeiros (1998) é de $1,50 \mathrm{dS} \mathrm{m}^{-1}$ e $1,55 \mathrm{dS} \mathrm{m}^{-1}$, respectivamente, enquanto, Silva (2002) observou maior tolerância, obtendo valor limiar de $3,58 \mathrm{dS} \mathrm{m} \mathrm{m}^{-1}$. Justifica Silva (2002), que o maior valor para tolerância da cultura pode ser atribuído ao fato de se ter investigado, no seu caso, a salinidade causada por excesso de fertilizantes, não computando os prejuízos do sódio, como certamente tiveram Maas \& Hoffman (1977) e Medeiros (1998), em salinidade motivada por águas salinas.

Durante o experimento foram observados sintomas de clorose e necrose nas bordas de algumas folhas baixeiras (Tabela 14), justamente as que podiam ser eventualmente molhadas durante as irrigações. Os sintomas observados (Figuras $14 \mathrm{e}$ 15) foram inicialmente atribuídos aos sais, que seriam absorvidos pelo tecido foliar após o contato com a água. Entretanto, tendo em vista que foram observados sintomas similares em plantas das testemunhas absolutas e também em plantas localizadas fora do experimento, não se pôde caracterizá-los definitivamente como efeitos da salinidade, a despeito da maior freqüência de folhas sintomáticas nos tratamentos irrigados com águas natural e residual (Tabela 14). É possível que os sintomas observados em plantas irrigadas com água dessalinizada sejam reflexos de problemas nutricionais da fase de sementeira. Esses problemas podem ter sido agravados pela absorção foliar de sais. Ressalva-se que nas plantas de tangerineira 'Cleópatra' não foram detectados, de maneira geral, quaisquer sintomas. Nas folhas desenvolvidas após o transplantio, estes sintomas também não foram identificados.

Francescato (1995) também registrou a ocorrência de necrose nas bordas das folhas de plantas cítricas cultivadas com menores freqüências de irrigação, atribuindo-a ao aumento de sólidos totais dissolvidos no substrato. As altas concentrações de nutrientes no substrato, promovidas pela disponibilidade precoce do fertilizante de liberação controlada, conduziram ao estiolamento e desenvolvimento vegetativo excessivo de mudas cítricas, no trabalho de Boaventura (2003). 
Tabela 14 . Número de folhas sintomáticas por tratamento, aos 30 DAT

\begin{tabular}{ccc}
\hline Porta-enxerto & Tratamento & Número de folhas sintomáticas \\
\hline \multirow{4}{*}{ 'Cleópatra' } & T1 & 0 \\
& T2 & 0 \\
& T3 & 0 \\
& T4 & 0 \\
T5 & 0 \\
T6 & 1 \\
& & \\
& T7 & 1 \\
'Cravo' & T8 & 2 \\
& T9 & 15 \\
& T10 & 49 \\
& T11 & 5 \\
& T12 & 24 \\
& T13 & 1 \\
& T14 & 1 \\
& T15 & 4 \\
'Swingle' & T16 & 23 \\
& T17 & 8 \\
& T18 & 29 \\
\hline
\end{tabular}

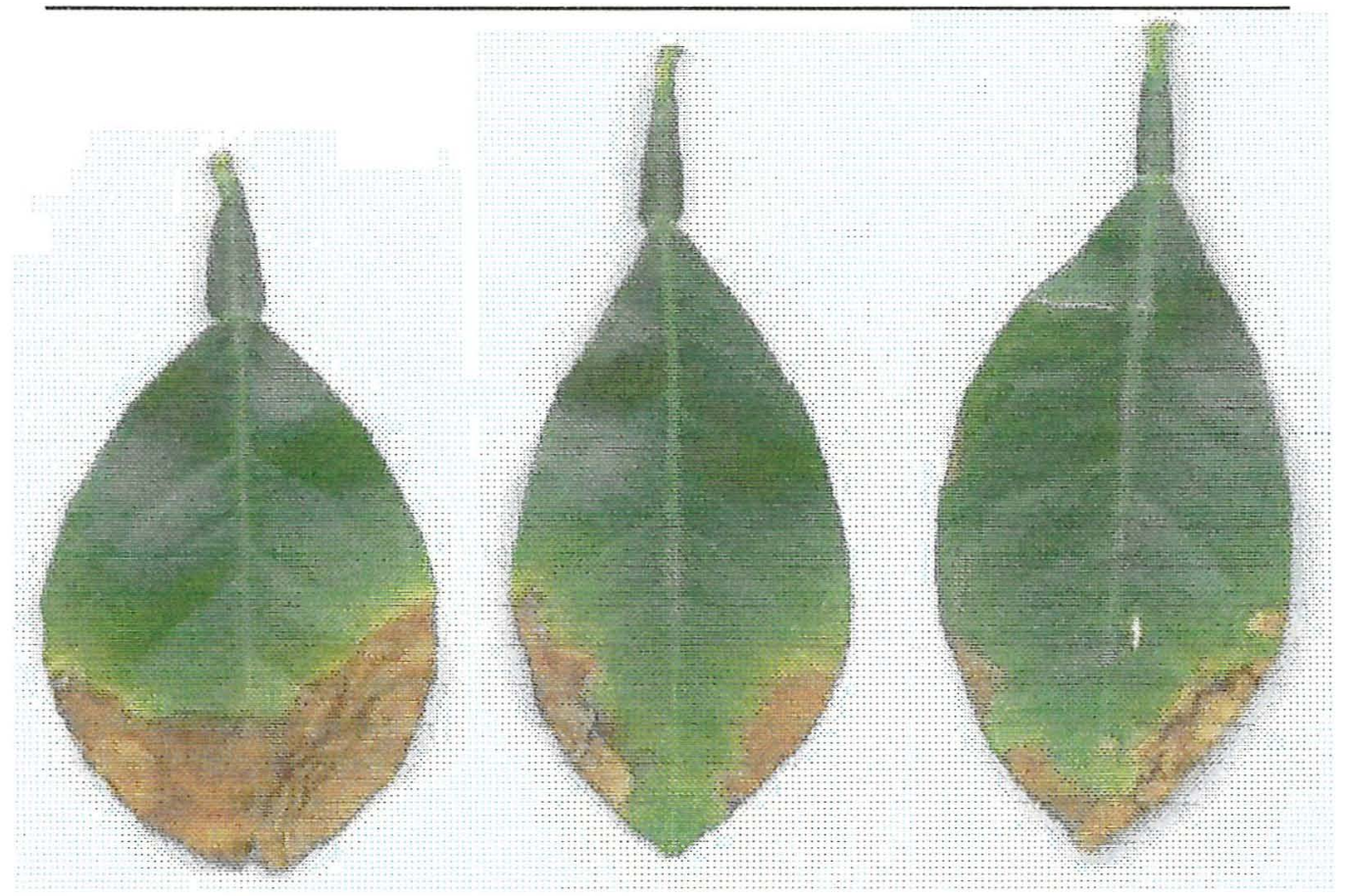

Figura 14 - Sintomas detectados em algumas folhas baixeiras de limoeiro 'Cravo' 


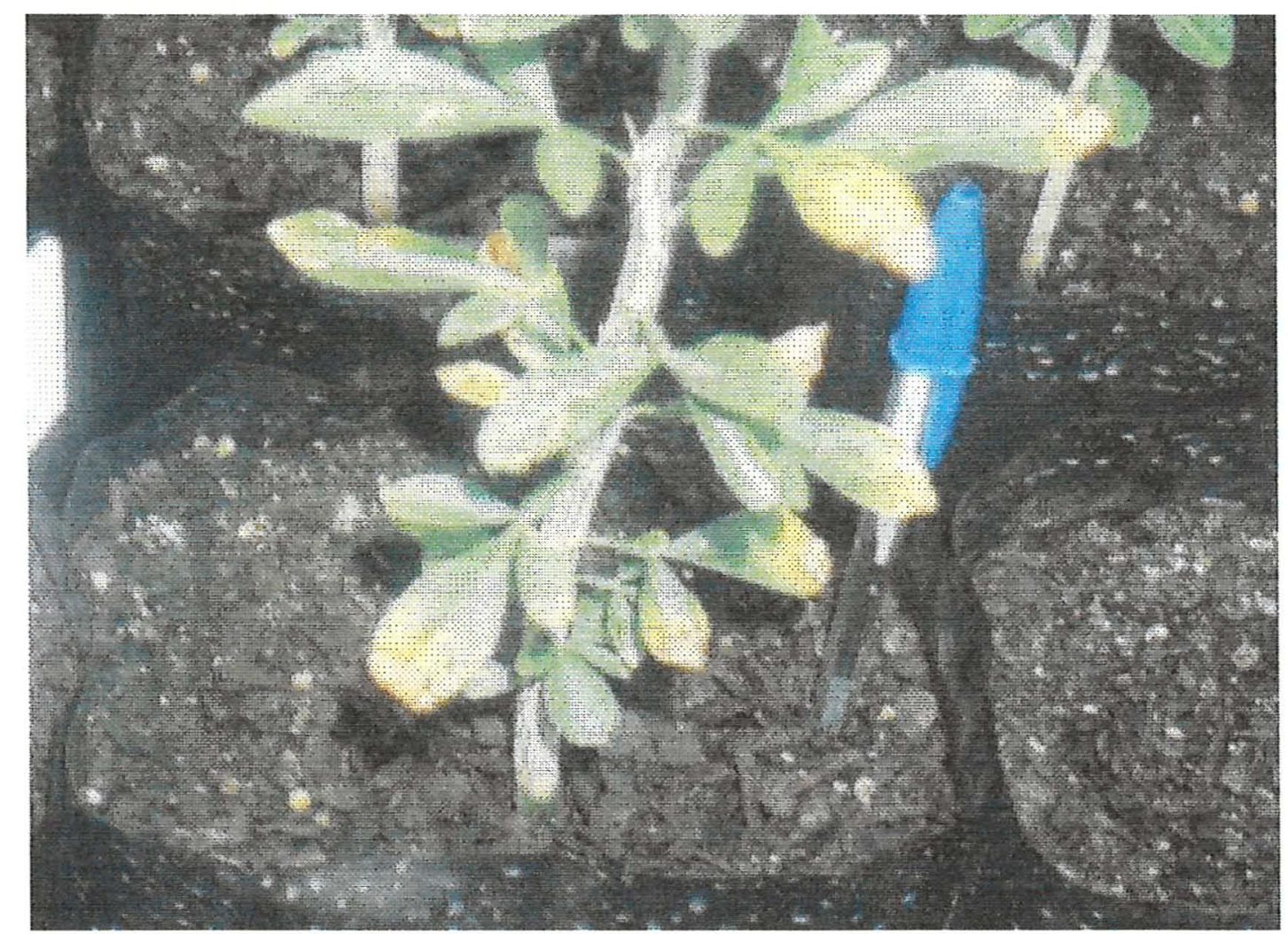

Figura 15 - Sintomas detectados em algumas folhas baixeiras de citrumeleiro 'Swingle'

Embora os sintomas não tenham sido exclusividade das plantas tratadas apenas com águas salinas, considerando se encontrar nestas uma maior freqüência de folhas sintomáticas, presume-se que se deve evitar irrigá-las por aspersão, especialmente $\operatorname{logo}$ após o transplantio, quando as plantas podem vir carreando desequilíbrios nutricionais da fase final da sementeira, os quais poderiam torná-las mais suscetíveis aos efeitos dos sais.

Conforme Ayers \& Westcot (1999), os sintomas da toxidez provocada por cloreto, inicialmente nas pontas das folhas, com progressão para o limbo, para culturas sensíveis como os citros, manifestam-se quando são alcançadas concentrações de 0,3 a 1,0\%, em base de peso. Para o sódio, os sintomas, iniciados sob a forma de queimaduras ou necrose ao longo dos bordos das folhas mais velhas, aparecem quando se atingem concentrações de 0,25 a $0,50 \%$, em base de peso. 
Analisando-se a Tabela 15, verifica-se que a concentração foliar de sódio não atinge seus limites críticos nas mudas experimentadas, independente do tratamento imposto. Já o cloreto aparece em concentração de injúria tão somente no tratamento 12 , em que o limoeiro 'Cravo' é submetido à irrigação com água residual, e com nitrato de cálcio.

Tabela 15 . Resultados da análise foliar para os três porta-enxertos, por tratamento*

\begin{tabular}{|c|c|c|c|c|c|c|c|c|}
\hline \multirow[t]{2}{*}{ Tratamento } & $\mathbf{N}$ & $\mathbf{P}$ & $\mathbf{K}$ & $\mathrm{Ca}$ & Mg & $\mathbf{S}$ & \multirow{2}{*}{$\begin{array}{l}\mathrm{Cl} \\
\% \\
\end{array}$} & \multirow{2}{*}{$\begin{array}{c}\mathrm{Na} \\
\%\end{array}$} \\
\hline & & 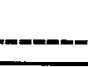 & $\mathrm{g} \mathrm{kg}^{-1}$ & & & & & \\
\hline \multicolumn{9}{|c|}{---Tangerineira 'Cleópatra'- } \\
\hline $\mathrm{T} 1$ & 33,5 & 2,8 & 17,1 & 21,2 & 3,7 & 2,8 & 0,10 & 0,043 \\
\hline $\mathrm{T} 2$ & 32,8 & 2,6 & 17,7 & 25,6 & 3,7 & 3,0 & 0,14 & 0,023 \\
\hline $\mathrm{T} 3$ & 31,5 & 2,5 & 18,9 & 23,6 & 3,5 & 3,2 & 0,14 & $0,05,1$ \\
\hline $\mathrm{T} 4$ & 33,3 & 2,7 & 19,8 & 23,8 & 3,7 & 2,8 & 0,14 & 0,060 \\
\hline T5 & 35,0 & 2,7 & 17,4 & 27,5 & 3,8 & 3,0 & 0,12 & 0,061 \\
\hline T6 & 33,1 & 2,5 & 18,3 & 23,7 & 3,4 & 3,2 & 0,14 & 0,090 \\
\hline $\mathrm{T} 7$ & 35,3 & 3,1 & 20,1 & 21,2 & 3,2 & 3,2 & 0,12 & 0,014 \\
\hline T8 & 37,5 & 2,9 & 17,7 & 26,2 & 3,7 & 3,0 & 0,16 & 0,010 \\
\hline $\mathrm{T} 9$ & 35,4 & 2,9 & 20,4 & 20,4 & 3,1 & 3,2 & 0,08 & 0,043 \\
\hline T10 & 35,2 & 3,0 & 21,3 & 20,7 & 3,5 & 3,2 & 0,12 & 0,082 \\
\hline $\mathrm{T} 11$ & 36,8 & 2,8 & 19,2 & 24,8 & 3,7 & 3,0 & 0,20 & 0,040 \\
\hline $\mathrm{T} 12$ & 35,4 & 2,9 & 20,1 & 26,9 & 4,1 & 3,2 & $0 ; 36$ & 0,076 \\
\hline \multicolumn{9}{|c|}{ Citrumeleiro 'Swingle'- } \\
\hline $\mathrm{T} 13$ & 38,1 & 2,3 & 18,0 & 24,7 & 4,5 & 3,5 & 0,20 & 0,031 \\
\hline $\mathrm{T} 14$ & 33,1 & 2,1 & 16,8 & 28,7 & 4,9 & 3,5 & 0,18 & 0,018 \\
\hline $\mathrm{T} 15$ & 40,9 & $2 ; 4$ & 19,5 & 25,1 & $4 ; 6$ & 3,5 & 0,14 & 0,035 \\
\hline T16 & 37,1 & 2,1 & 21,0 & 23,8 & 4,4 & 3,5 & 0,10 & 0,047 \\
\hline T17 & 40,4 & 2,1 & 19,5 & 30,0 & 4,9 & 3,4 & 0,14 & 0,053 \\
\hline $\mathrm{T} 18$ & 41,5 & 2,0 & 18,6 & 27,7 & 4,6 & 3,5 & 0,12 & 0,041 \\
\hline
\end{tabular}

* Análise efetuada no Laboratório de Ecologia Aplicada da ESALQ/USP.

De maneira geral, as concentrações de macronutrientes foliares não foram alteradas pelo tipo de água. A aplicação de nitrato de cálcio não resultou em aumento da concentraçâo foliar de nitrogênio, entretanto houve tendência de aumento da concentração de cálcio, e diminuição da de potássio. O tipo de água parece 
influenciar a concentração foliar de sódio, ficando a do cloreto variável. Como os dados apresentados não possibilitam contrastes estatísticos, por terem sido conformados de amostragem composta, não se pode atribuir a variação detectada na concentração de cloreto aos tipos de água ou aos tipos de porta-enxerto.

Supondo que os efeitos da salinização possam vir a suprimir o desenvolvimento posterior das plantas, na fase de pós-enxertia, seria interessante investigar o efeito da acumulação de sais desde o transplantio dos porta-enxertos até o ponto de comercialização das mudas enxertadas. Por outro lado, também seria pertinente averiguar o efeito isolado da salinização processada na fase de préenxertia sobre o crescimento das mudas enxertadas, o que seria possível irrigando-as tão somente com água dessalinizada a partir da enxertia. Estas informações orientariam o irrigante a escolher o tipo de água para cada fase do processo de produção de mudas, caso a oferta de água torne-se limitante, ou caso se pretenda diminuir os custos dả dessalinização dà água natural.

A primeira investigação foi concretizada com a enxertia de borbulhas de laranjeira "Valência" sobre as plantas remanescentes do experimento aqui discutido, sendo essas plantas continuadamente submetidas aos mesmos tratamentos. Os resultados da averiguação estão sendo analisados estatisticamente e, tão logo processados, permitirão conhecer a viabilidade da produção das mudas da laranjeira sobre os três porta-enxertos e com os níveis de salinidade e de nitrato de cátcio experimentados, no período necessário à sua completa formação, ou seja, desde o transplantio dos porta-enxertos até o alcance do ponto de comercialização. 


\section{CONCLUSÕES}

Considerando as condições nas quais o experimento foi conduzido, os resultados encontrados permitem concluir que:

- O desenvolvimento dos porta-enxertos de limoeiro 'Cravo', tangerineira 'Cleópatra' e citrumeleiro 'Swingle' não foi prejudicado pelos níveis de salinidade na água de irrigação, a despeito do aumento da salinidade registrado no substrato ao longo do período experimental.

- O nível de nitrato de cálcio aplicado às águas, além de não incrementar a taxa de desenvolvimento das plantas, mostrou-se prejudicial ao crescimento inicial do sistema radicular e ao engrossamento do caule.

- Não foram registrados sintomas de toxidez que pudessem ser atribuídos à absorção radicular de cloreto e/ou de sódio.

- Foram observadas diferenças significativas entre os tipos de porta-enxertos no que se refere ao seu desenvolvimento, havendo maior crescimento das plantas do limoeiro 'Cravo', seguidas pelas do citrumeleiro 'Swingle' e por último pelas da tangerineira 'Cleópatra'.

- O curto período necessário ao crescimento dos porta-enxertos, proporcionado pelo novo sistema de produção, associado às irrigações freqüentes e suas taxas de lixiviação, além da baixa CTC da casca de Pinus, podem ter restringido os efeitos negativos das águas salinas investigadas. 
ANEXOS 


\section{ANEXo A - eXigênCias mínimas para a produÇão de MUdas CÍTRICAS EM SÃO PAULO ${ }^{12}$}

A Agência de Defesa Agropecuária de São Paulo (ADAESP) regulamentou a partir de fevereiro de 2003, mediante a portaria ADAESP 1, que para a produção de mudas cítricas deve-se atender às seguintes exigências básicas:

a) desinfestação e desinfecção dos materiais e equipamentos utilizados com formalina a $2,5 \%$;

b) desinfestação e desinfecção de pisos, paredes e bancadas com hipoclorito de sódio a $1 \%$, após a retirada de cada partida de mudas produzidas;

c) o substrato, ou mistura utilizada, deve ter boa porosidade e ser isento de nematóides nocivos aos Citros, fungos do gênero Phytophtora e outros patógenos nocivos aos Citros;

d) as embalagens e substrato das mudas devem estar isentas de plantas daninhas;

e) a água de irrigação, deve ser tratada quando necessário, ficando isenta de nematóides nocivos aos Citros, fungos do gênero Phytophtora e outros patógenos comprovadamente nocivos aos Citros;

f) as sementes utilizadas deverão sofrer tratamento térmico a $52^{\circ} \mathrm{C}$ durante 10 minutos;

g) as mudas devem estar livres de doenças e pragas;

h) atendimento de todas as outras exigências em vigor.

Os viveiros e os depósitos de mudas cítricas devem atender às seguintes normas, segundo a portaria ADAESP 1:

a) ambiente protegido com tela de malha com abertura de, no máximo, $Q, 64$ $\mathrm{mm}$ por $0,20 \mathrm{~mm}$;

\footnotetext{
${ }^{12}$ Conforme Diário Oficial do Estado de São Paulo, Poder Executivo, Seção I, volume 113, número 29, terça-feira, 11 de fevereiro de 2003.
} 
b) acesso através de antecâmara, com piso de, no mínimo, $1 \mathrm{~m} \times 1 \mathrm{~m}$;

c) pedilúvio na entrada do ambiente (interior da antecâmara), para desinfestação de calçados;

d) bancada, no mínimo, a $30 \mathrm{~cm}$ do solo;

e) corredores entre bancadas com piso, com camada de pedra britada ou material similar, com um mínimo de $5 \mathrm{~cm}$ de espessura;

f) manutenção da área interna livre de plantas daninhas;

g) viveiro ou depósito a, no mínimo, $20 \mathrm{~m}$ de qualquer planta cítrica e em área de boa drenagem;

h) viveiro ou depósito livre de cigarrinhas vetores de Clorose Variegada dos Citros;

i) local acessivel para realização de inspeções;

j) instalação onde a legislação sanitária permita;

k) impedimentos à entrada de águas invasoras no ambiente;

1) acesso vetado a pessoas estranhas ao serviço;

m) viveiro ou depósito limpo de detritos vegetais;

n) atendimento de outras exigências fitossanitárias em vigor. 


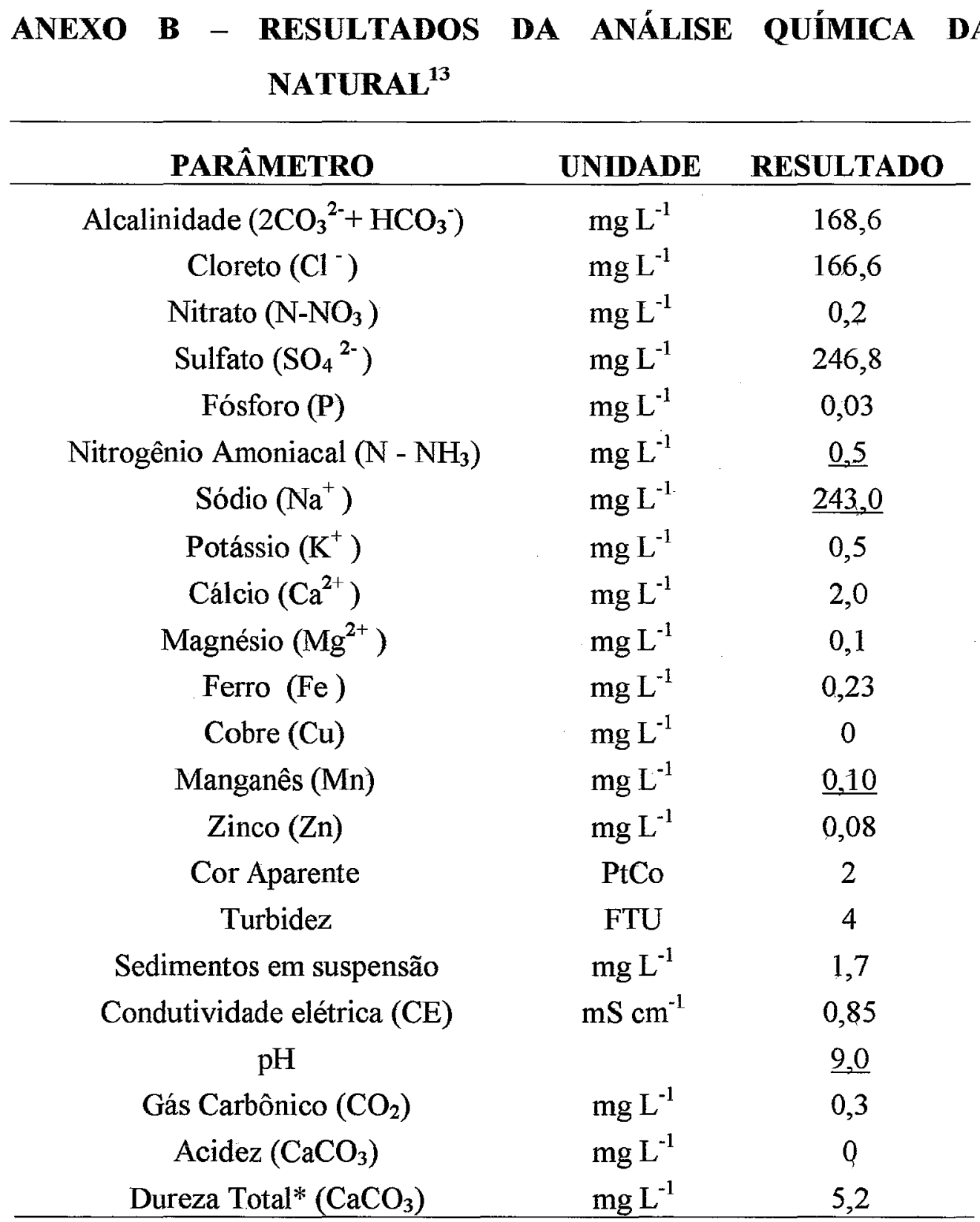

* Dureza Total calculado com base no equivalente de Carbonato de cálcio $\left(\mathrm{CaCO}_{3}\right)$ segundo Franson (1995): $2,497\left[\mathrm{Ca}, \mathrm{mg} \mathrm{L}^{-1}\right]+4,118\left[\mathrm{Mg}, \mathrm{mg} \mathrm{L}^{-1}\right]$

Franson, M.A.H.Standard methods for the examination of water and wastewater.

American Public Health Association, Washington, 19o. Edição, 1995.

${ }^{13}$ Amostrada em 21/02/2003. 


\section{ANEXo C - RESULTADOS DA ANÁlISE QUímica DA ÁGUA DESSALINIZADA ${ }^{14}$}

\begin{tabular}{|c|c|c|}
\hline PARAMMTRO & UNDADE & RESULTADO \\
\hline Alcalinidade $\left(2 \mathrm{CO}_{3}{ }^{2-}+\mathrm{HCO}_{3}^{-}\right)$ & $\mathrm{mg} \mathrm{L}^{-1}$ & 11,0 \\
\hline Cloreto $\left(\mathrm{Cl}^{-}\right)$ & $\mathrm{mg} \mathrm{L}^{-1}$ & 1,7 \\
\hline Nitrato $\left(\mathrm{N}-\mathrm{NO}_{3}\right)$ & $\mathrm{mg} \mathrm{L}^{-1}$ & 0,4 \\
\hline Sulfato $\left(\mathrm{SO}_{4}{ }^{2-}\right)$ & $\mathrm{mg} \mathrm{L}^{-1}$ & 2,2 \\
\hline Fósforo (P) & $\mathrm{mg} \mathrm{L}^{-1}$ & 0,03 \\
\hline Nitrogênio Amoniacal $\left(\mathrm{N}-\mathrm{NH}_{3}\right)$ & $m g L^{-1}$ & 0,4 \\
\hline Sódio $\left(\mathrm{Na}^{+}\right)$ & $\mathrm{mg} \mathrm{L}^{-1}$ & 5,7 \\
\hline Potássio $\left(\mathrm{K}^{+}\right)$ & $\operatorname{mg~L} L^{-1}$ & 0,10 \\
\hline Cálcio $\left(\mathrm{Ca}^{2+}\right)$ & $\mathrm{mg} \mathrm{L}^{-1}$ & 0,18 \\
\hline Magnésio $\left(\mathrm{Mg}^{2+}\right)$ & $\mathrm{mg} \mathrm{L}^{-1}$ & 0,04 \\
\hline Ferro $(\mathrm{Fe})$ & $\mathrm{mg} \mathrm{L}^{-1}$ & 0,19 \\
\hline Cobre $(\mathrm{Cu})$ & $\mathrm{mg} \mathrm{L}^{-1}$ & 0 \\
\hline Manganês (Mn) & $\mathrm{mg} \mathrm{L}^{-1}$ & 0,10 \\
\hline Zinco $(\mathrm{Zn})$ & $\mathrm{mg} \mathrm{L}^{-1}$ & 0,09 \\
\hline Cor Aparente & $\mathrm{PtCo}$ & 0 \\
\hline Turbidez & FTU & 0 \\
\hline Sedimentos em suspensão & $\mathrm{mg} \mathrm{L}^{-1}$ & 1,7 \\
\hline Condutividade elétrica $(\mathrm{CE})$ & $\mathrm{mS} \mathrm{cm}^{-1}$ & 0,07 \\
\hline $\mathrm{pH}$ & & 6,6 \\
\hline Gás Carbônico $\left(\mathrm{CO}_{2}\right)$ & $\mathrm{mg} \mathrm{L}^{-1}$ & 4,4 \\
\hline Acidez $\left(\mathrm{CaCO}_{3}\right)$ & $\mathrm{mg} \mathrm{L}^{-1}$ & 10,9 \\
\hline Dureza Total $*\left(\mathrm{CaCO}_{3}\right)$ & $\mathrm{mg} \mathrm{L}^{-1}$ & 0,6 \\
\hline
\end{tabular}

* Dureza Total calculado com base no equivalente de Carbonato de cálcio $\left(\mathrm{CaCO}_{3}\right)$ segundo Franson (1995): $2,497\left[\mathrm{Ca}, \mathrm{mg} \mathrm{L}^{-1}\right]+4,118\left[\mathrm{Mg}, \mathrm{mg} \mathrm{L}^{-1}\right]$

Franson, M.A.H.Standard methods for the examination of water and wastewater. American Public Health Association, Washington, 19o. Edição, 1995.

${ }^{14}$ Amostrada em 21/02/2003. 


\section{ANEXo D - RESUltados DA ANÁlise Química da ÁguA RESIDUAL ${ }^{15}$}

\begin{tabular}{|c|c|c|}
\hline PARÂMETRO & UNIDADE & RESULTADO \\
\hline Alcalinidade $\left(2 \mathrm{CO}_{3}{ }^{2-}+\mathrm{HCO}_{3}{ }^{-}\right)$ & $\mathrm{mg} \mathrm{L}^{-1}$ & 323,4 \\
\hline Cloreto $\left(\mathrm{Cl}^{-}\right)$ & $\mathrm{mg} \mathrm{L}^{-1}$ & $\underline{334,2}$ \\
\hline Nitrato $\left(\mathrm{N}-\mathrm{NO}_{3}\right)$ & $m g L^{-1}$ & 0,4 \\
\hline Sulfato $\left(\mathrm{SO}_{4}{ }^{2-}\right)$ & $m g L^{-1}$ & $\underline{403,9}$ \\
\hline Fósforo $(\mathrm{P})$ & $\mathrm{mg} \mathrm{L}^{-1}$ & 0,04 \\
\hline Nitrogênio Amoniacal $\left(\mathrm{N}-\mathrm{NH}_{3}\right)$ & $\mathrm{mg} \mathrm{L}^{-1}$ & $\underline{0,6}$ \\
\hline Sódio $\left(\mathrm{Na}^{+}\right)$ & $\mathrm{mg} \mathrm{L}^{-1}$ & $\underline{395,0}$ \\
\hline Potássio $\left(\mathrm{K}^{+}\right)$ & $\mathrm{mg} \mathrm{L}^{-1}$ & 0,9 \\
\hline Cálcio $\left(\mathrm{Ca}^{2+}\right)$ & $\mathrm{mg} \mathrm{L}^{-1}$ & 3,4 \\
\hline Magnésio $\left(\mathrm{Mg}^{2+}\right)$ & $\mathrm{mg} \mathrm{L}^{-1}$ & 0,1 \\
\hline Ferro $(\mathrm{Fe})$ & $\mathrm{mg} \mathrm{L}^{-1}$ & 0,23 \\
\hline Cobre $(\mathrm{Cu})$ & $\mathrm{mg} \mathrm{L}^{-1}$ & 0 \\
\hline Manganês (Mn) & $\mathrm{mg} \mathrm{L}^{-1}$ & $\underline{0,12}$ \\
\hline Zinco $(\mathrm{Zn})$ & $\mathrm{mg} \mathrm{L}^{-1}$ & 0,10 \\
\hline Cor Aparente & $\mathrm{PtCo}$ & 0 \\
\hline Turbidez & FTU & 0 \\
\hline Sedimentos em suspensão & $\mathrm{mg} \mathrm{L}^{-1}$ & 10,3 \\
\hline Condutividade elétrica (CE) & $\mathrm{mS} \mathrm{cm} \mathrm{cm}^{-1}$ & 1,55 \\
\hline $\mathrm{pH}$ & & $\underline{8} 7$ \\
\hline Gás Carbônico $\left(\mathrm{CO}_{2}\right)$ & $\mathrm{mg} \mathrm{L}^{-1}$ & 1,1 \\
\hline Acidez $\left(\mathrm{CaCO}_{3}\right)$ & $\mathrm{mg} \mathrm{L}^{-1}$ & 0 \\
\hline Dureza Total* $\left(\mathrm{CaCO}_{3}\right)$ & $\mathrm{mg} \mathrm{L}^{-1}$ & 8,7 \\
\hline
\end{tabular}

* Dureza Total calculado com base no equivalente de Carbonato de cálcio $\left(\mathrm{CaCO}_{3}\right)$ segundo Franson (1995): 2,497 [Ca, $\left.\mathrm{mg} \mathrm{L}^{-1}\right]+4,118\left[\mathrm{Mg}, \mathrm{mg} \mathrm{L}^{-1}\right]$

Franson, M.A.H.Standard methods for the examination of water and wastewater.

American Public Health Association, Washington, 19o. Edição, 1995.

${ }^{15}$ Amostrada em 21/02/2003. 


\section{ANEXO E - CARACTERIZAÇ̃̃O DO RECIPIENTE DE CULTIVO}

Dimensões nominais da sacola plástica: $25 \times 32 \mathrm{~cm}$

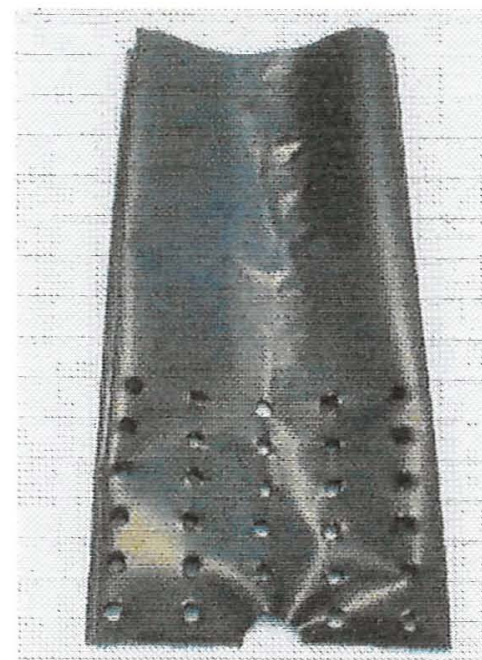

a)

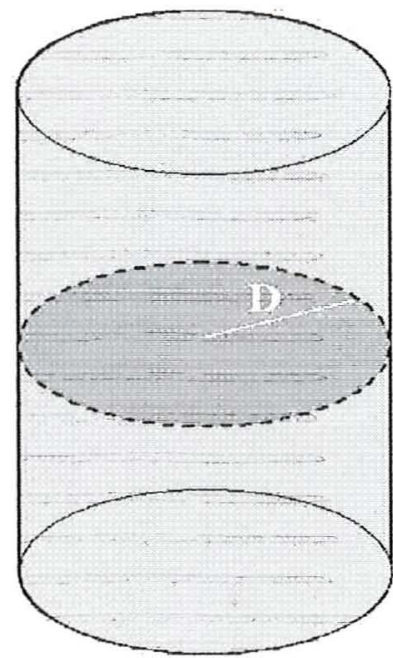

b)

Figura A1 - Sacola de polietileno preto usada nos experimentos (a) e sua forma cilíndrica (b) assumida após enchimento com substrato

Perímetro circular $(\mathrm{C})$ medido à metade da altura da sacola: $51 \mathrm{~cm}$ Altura da sacola $(\mathrm{H})$ após enchimento: $25 \mathrm{~cm}$

Diâmetro da sacola (D):

$\mathrm{D}=\frac{\mathrm{C}}{\pi}$

$\mathrm{D}=16 \mathrm{~cm}$

Área da sacola

$\mathrm{A}=\frac{\pi \times \mathrm{D}^{2}}{4}$

$A=201,06 \mathrm{~cm}^{2}$

Volume máximo comportado pela sacola

$\mathrm{V}=\mathrm{A} \mathrm{H}$

$\mathrm{V}=201,06 \mathrm{~cm}^{2} \times 25 \mathrm{~cm}$

$\mathrm{V}=5,02 \mathrm{~L}^{3}$ 


\section{ANEXo F - MEMória de CÁlculo PARA o Nível de cálcio ESTUDADO}

A aplicação suplementar de cálcio objetivou diminuir os efeitos tóxicos dos íons de sódio e cloreto. O estabelecimento do nível de cálcio a ser adotado foi baseado nas diretrizes da FAO apresentadas por Ayers \& Westcot (1999), as quais consideram para uma RAS (razão de absorção de sódio) variando entre 3 e 9 na água de irrigação um grau de restrição de uso de ligeiro a moderado.

Mediante a equação 8, as águas salinas natural e residual (Anexos B e D), apresentam, respectivamente, RAS iguais a 48,55 e 75,72, cujas restrições de uso são classificadas em severas.

$$
\mathrm{RAS}=\sqrt{\frac{\mathrm{Na}}{\frac{(\mathrm{Ca}+\mathrm{Mg})}{2}}}
$$

em que:

$\mathrm{Na}=$ concentração de sódio, meq $\mathrm{L}^{-1}$;

$\mathrm{Ca}=$ concentração de cálcio, meq $\mathrm{L}^{-1}$;

$\mathrm{Mg}=$ concentração de magnésio, meq $\mathrm{L}^{-1}$.

Adicionando $10 \mathrm{mM} \mathrm{L}^{-1}$ de cálcio, conforme estudo de Bañuls et al. (1991), correspondentes a $20 \mathrm{meq} \mathrm{L}^{-1}$ de cálcio, diminuem-se as RAS para 3,56 e 7,12, respectivamente, nas águas natural e residual.

A fonte de cálcio utilizada foi o nitrato de cálcio, aplicado na dose de 2,105 $\mathrm{g} \mathrm{L}^{-1}$, o que representa a adição de $400 \mathrm{mg} \mathrm{L}^{-1}$ de Ca e $326 \mathrm{mg} \mathrm{L}^{-1}$ de $\mathrm{N}$. O nitrato de cálcio foi escolhido dentre os demais corretivos para água de irrigação e solo, em razão de sua solubilidade elevada, sua alta eficiência em proporcionar cálcio, não conter cloreto e ser usual na nutrição de mudas cítricas. 


\section{ANEXo G - MEMória de CÁlculo PARA A FraÇÃo de LIXIVIAÇÃO ALMEJADA}

Conforme Ayers \& Westcot (1991), a fração de lixiviação (FL) para distintos grupos de culturas pode ser estimada mediante a Figura A2, em que a salinidade do solo representa a salinidade limiar tolerada (CEes) pelas espécies.

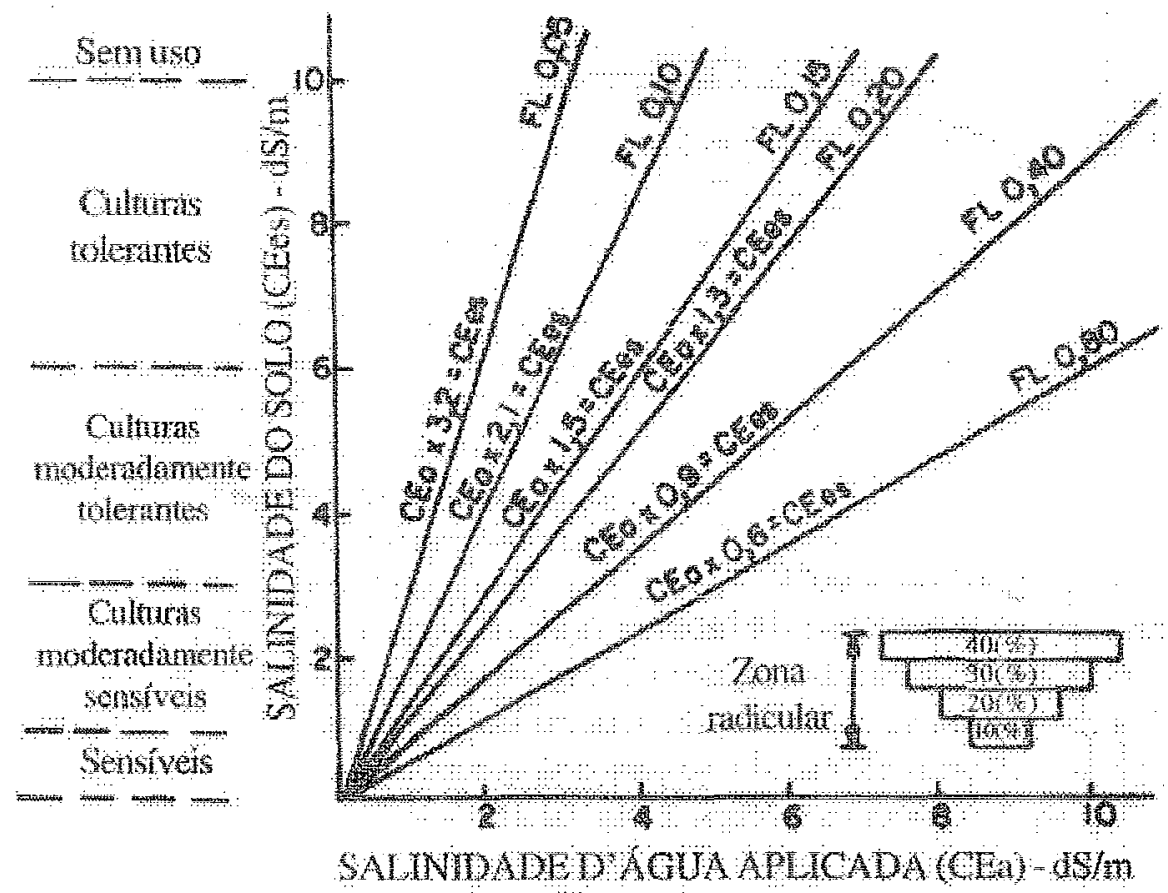

Figura A2 - Efeito da salinidade da água de irrigação (CEa) sobre a salinidade média do solo (CEes) na zona radicular para várias frações de lixiviação (FL)

Considerando a salinidade limiar dos citros em $1,4 \mathrm{dS} \mathrm{m}^{-1}$ obtida no extrato de saturação (Maas, 1993), e aceitando a salinidade da água natural (CEa) da Citrograf Mudas em 1,21 dS m$~^{-1}$, estima-se mediante a figura acima uma necessidade de lixiviação entre 15 a $20 \%$.

Também utilizando os mesmos valores na eq. (9) proposta por Rhoades (1974), tem-se como necessidade de lixiviação $17 \%$. 
$\mathrm{NL}=\frac{\mathrm{CEa}}{5 \mathrm{CEes}-\mathrm{CEa}}$

em que:

$\mathrm{NL}=$ necessidade de lixiviação, decimal;

$\mathrm{CEa}=$ condutividade elétrica da água de irrigação, $\mathrm{dS} \mathrm{m}^{-1}$;

CEes $=$ condutividade elétrica do extrato de saturação do solo ao se atingir um equilíbrío dinâmíco com a água de irrígação, $\mathrm{dS} \mathrm{m}^{-1}$.

As frações de lixiviação estimadas com as metodologias acima consentem com as preconizadas por Martínez (2002) para manejo da irrigação em recipientes sob ambiente protegido. Registra-se também que a fração de $20 \%$ é normalmente utilizada nas irrigações na Citrograf Mudas, sendo ainda, conforme Milner (2002) empregada em outros viveiros de produção de mudas cítricas no Brasil.

Neste sentido, durante a fase de planejamento do experimento estabeleceuse aplicar uma fração lixiviação de $20 \%$ em cada irrigação. 


\section{REFERÊNCIAS BIBLIOGRÁFICAS}

ABAD, M.; MARTINEZ, M. D.; MARTINEZ, P. F.; MARTINEZ, J. Evaluación agronómica de los sustratos de cultivo. Actas de Horticulture, n.11, p. 141-154, 1992.

ABU-AWWAD, A. M. Influence of different water quantities and qualities on lemon trees and soil salt distribution at the Jordan Valley. Agricultural Water Management, v.52, p.53-71, 2001.

ABREU, M. F.; ABREU, C. A.; BATAGLIA, O. C. Uso da análise química na avaliação da qualidade de substratos e componentes. In: FURLANI, A. M. C.; BATAGLIA, O. C.; ABREU, M. F.; ABREU, C. A.; FURLANI, P. R.; QUAGGIO, J. A.; MINAMI, K. Caracterização, manejo e qualidade de substratos para produção de plantas. Campinas: Instituto Agronômico, 2002. p.17-28. (IAC. Documentos, 70).

AMERICAN SOCIETY OF CIVIL ENGINEERS. Agricultural salinity assessment and management. New York: ASCE, 1990. 619p (ASCE Manuals and Reports on Engineering Practice, n.71). 
AYERS, R.S.; WESTCOT, D. W. Qualidade de água na agricultura. Trad. GHEYI, H.R.; MEDEIROS, J.F.; DAMASCENO, F.A.V. Campina Grande: UFPB, 1991. 218p. (FAO. Estudos de Irrigação e Drenagem, 29).

BAÑULS, J; PRIMO-MILLO, E. Effects of salinity on some Citrus scion rootstock combinations. Annals of Botany, v.76, p.97-102, 1995.

BAÑULS, J.; LEGAZ, F; PRIMO-MILLO, E. Salinity-calcium interactions on growth and ionic concentration of Citrus plants. Plant and Soil, v.133, p.39-46, 1991.

BERNARDI, A. C. C. Produção de mudas de citros em vasos em função da adubação com nitrogênio, fósforo e potássio. Piracicaba, 1999, 84p. Tese (Doutorado) - Escola Superior de Agricultura "Luiz de Queiroz", Universidade de São Paulo.

BOAVENTURA, P. S. R. Demanda por nutrientes de porta-enxertos e mudas cítricas produzidas em substratos em ambiente protegido. Campinas, 2003, 62p. Dissertação (Mestrado) - Instituto Agronômico de Campinas.

BORGES, R. de S.; ALMEIDA, F. J.; SCARANARI, C.; MACHADO, A. M.; CARVALHO, S. A.; COLETTA FILHO, H. D.; AGUILAR-VILDOSO, C.I. Programa IAC/CNPq de incentivo à produção e difusão de mudas de citros isentas da clorose variegada dos citros e outras doenças. Laranja, 21, n.1, p.205224,2000 .

CADAHÍA, C. Fertirrigacion. In: NUEZ, F. El cultivo do tomate. Madrid: Ediciones Mundi-Prensa, 1995. p.167-187. 
CADAHIIA, C. Fertirrigacion: cultivos hortícolas y ornamentales. 2.ed. Madrid: Ediciones Mundi-Prensa, 2000. 475p.

CADAHÁ, C.; EYMAR, E. Caracterización química y físioquimica de sustratos. Actas de Forticulture, n.11, p.19-25. 1992.

CAN, H. Z.; AKSOY, U.; ANAÇ, S.; KUKUL, Y. S.; OKUR, B. Response of Satsuma mandarin (Citrus unshiu Marc.) trees budded on Trifoliate orange ( $P$. trifoliata) to salinity due to seawater intrusion. Acta Horticulturae, v. 573, p. $265-270,2002$.

CARVALHO, S. A. Estratégias para estabelecimento e manutenção de matrizes, borbulheiras e viveiro de citros em ambiente protegido. In: SEMINÁRIO INTERNACIONAL DE CITROS - TRATOS CULTURAIS, 5., Bebedouro, 1998. Anais. Bebedouro: Fundação Cargill, 1998. p.67-101.

CARVALHO, S. A. Propagação dos citros. Informe Agropecuário, v. 22, n. 209, p.21-25, 2001.

CARVALHO, S. A. Regulamentação atual da agência de defesa agropecuária para produção, estocagem, comércio, transporte e plantio de mudas cítricas no Estado de São Pàulo. Laranja, v.24, n. 1, p. 199-239, 2003.

CASTLE, W. S.; FERGUSON, J. J. Current status of greenhouse and container productions of citrus nursery trees in Florida. Proceedings of Florida State Forticultural Society, v.95, p.42-46, 1982. 
CASTLE, W. S.; ROUSE, R. E. Total mineral nutrient content of Florida citrus nursery plants. Proceedings of Florida State Forticultural Society, v.103, p.42-44, 1990.

COORDENADORIA DE ASSISTÊNCIA TÉCNICA INTEGRAL. Normas para produção de muda certificada de citros. Campinas: Secretaria de Agricultura e Abastecimento, 23 p, 1994. 23p.

CRUZ, J. L., PELACANI, C. R., SOARES FILHO, W. S., CASTRO NETO, M. T., COELHO, E. F., DIAS, A. T., PAES, R. A. Influência da salinidade sobre o crescimento do limoeiro 'Cravo' In: CONGRESSO BRASILEIRO' DE FRUTICULTURA, 17., Belém, 2002. Anais. Belém: SBF, 2002, CD-Rom.

DAEE. Águta subterrânea: reserva estratégica. Revista Águas e Energia Elétrica, 13, p.14-23, 1988.

ESTANISLAU, M. L. L.; BOTEON, M.; CANÇADO JÚNIOR, F. L.; PAIVÁ, B. M. de. Laranjas e sucos: aspectos econômicos. Informe Agropecuário, v. 22, n. 209, p. $8-20,2001$.

FAO. Agriculture production: citrus production. Rome, 2002. $<\mathrm{http}: / /$ www.fao.org $>$ (18 out. 2003).

FERMINO, M. H. O uso da análise física na avaliação da qualidade de componentęs e substratos. In: FURLANI, A. M. C.; BATAGLIA; O. C.; ABREU, M. F.; ABREU, C. A.; FUREANI, P. R:; QUAGGIO; J. A.; MINAMI; K. Caracterização, manejo e qualidade de substratos para produção de plantas. Campinas: Instituto Agronômico, 2002: p. 29-37. (IAC. Documentos, $70)$. 
FORNER, J. B.; FORNER-GINER, M. A. Programa de melhoramento de portaenxertos cítricos na Espanha. In: SEMINÁRIO INTERNACIONAL DE CITROS - MELHORAMENTO, 7., Anais. Bebedouro: Estação Experimental de Bebedouro, 2002 (CD Rom).

FRANCESCATO, R.D.C. Influência de freqüência de irrigação, substrato e adubo de liberação lenta na produção de porta-enxerto cítrico de limão 'Cravo' (Citrus limonia, Osbeck). Piracicaba, 1995, 116p. Dissertação (Mestrado) - Escola Superior de Agricultura "Luiz de Queiroz", Universidade de São Paulo.

FUNDECITRUS. Inspeção de viveiros, relatório mensal. Araraquara, 2003. Disponível em $<$ http://www.fundecitrus.com.br $>$ (20 out. 2003).

GALLASCH, P. T.; DALTON, G.S. Selecting salt-tolerant Citrus rootstocks. Australian Journal os Agricultural Research, v.40, p. 137-144, 1989.

GARCÍA-LEGAZ, M. F.; ORTIZ, J. M.; GARCÍA-LIDÓN, A.; CERDÁ, A. Effect of salinity on growth, ion content and $\mathrm{CO}_{2}^{-}$assimilation rate in lemon varieties on different rootstocks. Physiologia Plantarum, v.89, p. 427-432, 1993.

GARCÍA-SÁNCHES, F.; CARVAJAL, M.; SÁNCHEZ-PINA, M. A.; MARTÍNEZ, V.; CERDÁ, A. Salinity resistance of Citrus seedlings in relation to hydraulic conductance, plasma membrane ATPase and anatomy of the roots. Journal of Plant Physiology, v. 156, p.724-730, 2000. 
GERVÁSIO, E. S. Efeito de lâminas de irrigação e doses de condicionador, associadas a diferentes tamanhos de tubetes, na produção de mudas de cafeeiro. Piracicaba, 2003, 105p. Tese (Doutorado) - Escola Superior de Agricultura "Luiz de Queiroz", Universidade de São Paulo.

GIRARDI, E. A.; MOURAO FILHO, F. A. A.; GRAF, C. C. D; OLIC, F. B. Growth of citrus nursery trees related to the container volume. In: INTERNATIONAL CONGRESS OF CITRUS NURSERYMEN, 6., Ribeirão Preto-SP, 2001. Proceedings, Ribeirão Preto: ICSN, 2001a, p.316-319.

GIRARDI, E. A.; MOURAO FILHO, F. A. A.; GRAF, C. C. D; OliC; F. B. Influence of the source and dosage of slow-release fertilizers on containerized citrus nursery trees. In: INTERNATIONAL CONGRESS OF CITRUS NURSERYMEN, 6., Ribeirão Preto -SP, 2001. Proceedings, Ribeirão Preto: ICSN, 2001b, p.258-262.

GRAF, C. C. D: Produção de mudas sadias. In: Empresa Agropecuária de Minas Gerais. Citricultura do Triângulo Mineiro e Alto Parnaíba. Uberaba, 1999, p.37-40.

GRAF, C. C. D. Vivecitrus e a produção de mudas certificadas. Laranja, v.22, n.2, p.533-548, 2001.

GRAZIANO; J. R. Normas para produção de muda certificada de citros. Laranja, v.19, n.2, p.411-421, 1998.

HEPAKSOY, S.; OZZER, B; CAN, H. Z. Influence of rootstocks on physiological response of Satsuma mandarin (Citrus unshiu Marc.) to salinity. Acta Horticulturae, v. 573, p. 247-253, 2002. 
HOLANDA, J. S.; AMORIM, J.R.A. Qualidade da água para irrigação. In: GHEYI, H.R.; QUEIROZ, J. E.; MEDEIROS, J. F. (Ed.) Manejo e controle da salinidade na agricultura irrigada. Campina Grande: UFPB/SBEA, 1997. cap. 5, p.137-1.70.

LEVY, Y.; SHALFEVET, J. Ranking the salt tolerance of citrus rootstocks by juice analysis. Scientia Horticulturae, v. 45, p.89-98, 1990.

LEVY, Y;; LIFSHITZ, J.; MAEACH, Y de; DAVHD; Y. The response of several Citrus genotypes to high-salinity irrigation water. HortScience, v. 34, n. 5 , p.878-881, 1999.

LLOYD, J.; HOWIE, H. Response of orchad 'Washington navel' ${ }^{2}$ orange, Citrus sinensis (L.) Osbeck to saline irrigation water. I Canopy characteristics and seasonal patterns in leaf osmotic potential, carbohydrates and ion concentrations. Australian Journal of Agricultural Research, v.40, p.359-369, 1989.

LLOYD, J.; KRIEDEMANN, P. E.; ASPTNALL, D. Contrast between Citrus species in response to salinisation: an analysis of photosynthesis and water relations for differentt rootstocks-scion combinations. Physiologia Plantarum, v.78, p. 236-246, 1990.

MAAS, E.V.; HOFFMAN, G.J. Crop salt tolerance - Current Assessment. Journal of Irrigation and Drainage Division ASCE, v. 103, n IR2, p.115-134, 1977.

MAAS, E. V. Sălinity and citriculture. Tree Physiology, v. 12, p.195-216, 1993.

MAIA NETO, R.F. Água para o desenvolvimento sustentável. A água em Revista, n.9, p.21-32, 1997. 
MARTíNEZ, P.-F. Manejo de sustratos para horticultura. In: FURLANI, A. M. C; BATAGlia, O. C.; ABREU, M. F.; ABREU, C. A.; FURLANI, P. R.; QUAGGIO, J. A.; MINAMI, K. Caracterização, manejo e qualidade de substratos para produção de plantas. Campinas: Instituto Agronômico, 2002. p. 53-76. (IAC. Documentos, 70).

MATTOS, P. P.; DONADIO, L. C.; BANZATTO, D. A.. Efeito do uso de diferentes substratos sobre o desenvolvimento de três porta-enxertos de citros em recipientes. In: CONGRESSO BRASILEIRO DE FRUTICULTURA, 9., Campinas, 1987. Anais. Campinas: Sociedade Brasileira de Fruticultura, 1988. p. 351-354.

MEDEIROS, J.F. Manejo da água de irrigação salina em estufa cultivada com pimentão. Piracicaba, 1998. 152p. Tese (Doutorado) Escola Superior de Agricultura "Luiz de Queiroz", Universidade de São Paulo.

MEDINA, C. L. Trocas gasosas e relações hídricas de laranjeira 'Valência' enxertada sobre quatro porta-enxertos e submetida à deficiência hídrica. Piracicaba, 1997. 79p. Dissertação (Mestrado) Escola Superior de Agricultura "Luiz de Queiroz", Universidade de São Paulo.

MILNER, L. Water and fertilizers management in substrates. In: INTERNATIONAL CONGRESS OF CITRUS NURSERYMEN, 6., Ribeirão Preto, $20,01$. Proceedings, Ribeirão Preto:ICSN, 2001. p. 93-95. 
MILNER, L. Manejo de irrigação e fertirrigação em substratos. In: FURLANI, A. M. C.; BATAGLIA, O. C.; ABREU, M. F.; ABREU, C. A.; FURLANI, P. R.; QUAGGIO, J. A.; MINAMI, K. Caracterização, manejo e qualidade de substratos para produção de plantas. Campinas: Instituto Agronômico, 2002. p. 45-51. (IAC. Documentos, 70).

MONTEIRO, C. A. F. A dinâmica climática e as chuvas do Estado de São Paulo. São Paulo: Instituto de Geografia/USP, 1973.

MOORE, P. W. Propagation and growing citrus nursery trees in containers. Proceedings of International Society Citriculture. p.129-131, 1978.

MORINAGA, K.; SYKES, S. R. Effect of salt and water stress on fruit quality, physiological responses, macro- and micro-element contents in leaves of Satsuma Mandarin Trees under greenhouse conditions. JARQ, v.53, n.1, p.53$58,2001$.

MOURÃO FILHO, F.A.A.; DIAS, C.T.S.; SALIBE, A.A. Efeito da composição do substrato na formação de mudas de laranjeira 'Pera'. Scientia Agrícola, v.55, n.1, p.35-42, 1998.

MULLER, G. W.; NEGRI, J. D.; AGUILAR-VILDOSO, C. I.; MATTOS JÚNIOR, D.; POMPEU JÚNIOR, J.; TÓFILO SOBRINHO; J; CARVALHO, S. A.; GIROTTO; L. F.; MACHADO; M. A. Morte súbita dos citros: uma nova doença na citricultura brasileira. Laranja, v.23, n.2, p.371-386, 2002.

NEVES, E. M. Citricultura brasileira: efeitos econômico-financeiros. Revista Brasileira de Fruticultura, v.23, v.2, p.432-436, 2001. 
NIEVES, M.; GARCIA, A.; CERDÁ, A. Effects of salinity rootstocks on lemon fruit quality. Journal of Horticultural Science, v. 66, p.127-130, 1991.

NIEVES, M.; MARTINEZ, V, CERDÁ, A; GULLLÉN, M. G. Yield and mineral composition of 'Verna" lemon tress as affected by salinity and rootstock combination. Journal of Horticultural Science, v. 65, p.359-366, 1990.

NAUER,E. M.; ROISTACHER, C. N.; LABANAUSKAS, C. K. Growing citrus in modified UC potting mixtures. California Citrograph, v.53, n.2, p.1-3, 1968.

OLIC, F.B.; MOURÃO FILHO, F.A.A.; GRAF, C.C.D.; GIRARDI, E.A.; SALVO, J.G.; COLEHO, R.D. Vegetative growth of containerized citrus nursery trees subjected to five levels of irrigation. In: INTERNATIONAL CONGRESS OF CITRUS NURSERYMEN, 6., Ribeirão Preto, 2001. Proceedings, Ribeirão Preto: ISCN, 2001. p. 131-133.

OLIVEIRA, A. S. de; SALATI, E. Um estudo sobre as águas subterrâneas da região de Piracicaba. Anais da ESALQ, v.38, p.885-907, 1981.

OLIVEIRA, R. P.; SCIVITTARO, W. B.; BORGES, R. S.; NAKASU, B. H. Mudas de citros. Pelotas: Embrapa Clima Temperado, 2001. 32p.

OPPENHEIMER, H. R. Injurious salts and the ash composition of fruit trees. Fadar, v.10, p.3-16, 1937.

PAZ, V. P. da S.; TEODORO, R. E. F.; MENDONÇA, F. C. Recursos hídricos, agricultura irrigada e meio ambiente. Revista Brasileira de Engenharia Agrícola e Ambiental, v.4, n.3, p.465-473, 2000. 
PLATT, R. G.; OPITZ, K. W. The propagation of citrus. In: PLATT, R.G.; OPITZ, K.W.; JORDAN, L. S. et al. The Citrus Industry. Berkeley: University of California, 1973. cap.1, p.1-47.

POMPEU JÚNIOR, J. Porta-enxertos para citros. In: RODRIGUEZ, O.; VIEGAS, F. C. P.; POMPEU JÚNIOR, J.; AMARO; A. (Ed.) Citricultura brasileira, 2 ed. Campinas: Fundação Cargill, 1991, v. 1, p.265-280.

REZENDE, L. P.; AMARAL, A. M.; CARVALHO, S. A.; SOUZA, M. Volume de substrato e superfosfato simples na formação do limoeiro 'Cravo ${ }^{2} \mathrm{em}$ vasos. I. Efeitos no crescimento vegetativo. Laranja, v.16, n.2, p.155-164, 1995.

ROMERO-ARANDA, R.; SYVERTSEN; J.P. The influence of foliar-applied urea nitrogen and saline solutions on net gas exchange of Citrus leaves. Journal of American Society Horticulturat Science, v. 121, n.3, p. 501-506, 1996.

RUSCHEL, J. Crescimento e estado nutricional de mudas de citros influenciadas pela adubação com nitrogênio, fósforo, potássio e cálcio. Piracicaba, 2002, 69p. Tese (Doutorado) - Escola Superior de Agricultura "Luiz de Queiroz", Universidade de São Paulo.

SILVA, E. F. F. Manejo da fertirrigação e controle dà salinidade na cultura do pimentão utilizando extratores de solução do solo. Piracicaba, 2002, 136p. Tese (Doutorado) - Escola Superior de Agricultura "Luiz de Queiroz", Universidade de São Paulo.

STOREY, R. Salt tolerance, ion relations and the effect of root medium on the response of Citrus to salinity. Australian Journal of Plant Physiology, v.22, p.101-114, 1995. 
STOREY, R.; WALKER, R. R. Citrus and salinity. Scientia Horticulturae, v.78, p.39-81, 1999.

SYKES, S. R. The inheritance of salt exclusion in woody perennial fruit species. Plant and Soil, n. 146, p.123-129, 1992.

TAVEIRA, J. A. M. Fibra de coco: Uma nova alternativa para formação de mudas cítricas. Ciência \& Prática, v.2, n.6, p.9, 2002.

TAVEIRA, J. A. M. Growing media utilization in containerized citrus tree production. In: INTERNATIONAL CONGRESS OF CITRUS NURSERYMEN, 6., Ribeirão Preto, 2001. Proceedings, Ribeirão Preto: ISCN, 2001. p. 189-192.

TOZLU, I.; GUY, C. L.; MOORE, G. A. Breeding Citrus for salt tolerance. Acta Horticulturae, n.573, p.255-263, 2002.

VALLE, M.G. Impactos na citricultura paulista decorrentes da implementação de técnicas de produção de borbulhas e mudas sadias de citros. Laranja, v.23, n.2, p. $271-280,2002$.

VERMEIREN; L.; JOBLING, G.A. Irrigação localizada. Roma: FAO, 1980. 184 p.

WARNCKE, D.D. Testing artificial growth media and interpreting the results. In: WESTERMAN (Ed). Soil Testing and Plant Analysis. 3.ed. Madison: American Society of Agronomy, p.337-357, 1990. 
WHITE, J. W.; MASTALERZ, J. W. Soil moisture as related to 'container capacity'. American Society for Horticultural Science, v.89, p.758-765, 1966.

YANG, S. L.; YANO, T.; AYDIN, M.; KITAMURA, Y.; TAKEUCHI, S. Short term effects of saline irrigation on evapotranspiration from lysimeter-grown Citrus trees. Agricultural Water Management, v. 56, p. 131-141, 2002.

ZANETTI, M; CAZETTA; J. O; CARVALHO, S. A; GRAF, C. C. G. Desenvolvimento vegetativo de mudas de citros em substrato de fibra de coco sob diferentes níveis de irrigação (compact disc). CONGRESSO BRASILEIRO DE FERTIRRIGAÇÃO, 1., João Pessoa, 2003. CONBRAFERTI: trabalhos. João Pessoa: UFPB/Embrapa Semi Árido, 2003.

ZEKRI, M; PARSONS, L. R. Calcium influences growth and leaf mineral concentration of Citrus under saline conditions. Hortscience, v. 25, n. 7, p. 784786,1990 .

ZEKRI, M.; PARSONS, L. R. Salinity tolerance of citrus rootstocks: Effects of salt on root and leaf mineral concentrations. Plant and Soil, v. 147, p. 171-181, 1992 . 


\section{APÊNDICES}


APÊNDICE 1 . DADOS DO MONITORAMENTO DA CONDUTIVIDADE ELÉTRICA PARA OS TRÊS TIPOS DE ÁGUAS DE IRRIGAÇÃO SEM NITRATO DE CÁLCIO

\begin{tabular}{|c|c|c|c|}
\hline \multirow[b]{2}{*}{ Data } & \multicolumn{3}{|c|}{$\operatorname{CEa}\left(\mathrm{dS} \mathrm{m}^{-1}\right)$} \\
\hline & Água residual & Água dessalinizada & Água natural \\
\hline $18 / 2 / 03$ & 2,23 & 0,03 & 1,22 \\
\hline $19 / 2 / 03$ & $n c^{*}$ & 0,03 & 1,23 \\
\hline $20 / 2 / 03$ & $\mathrm{Nc}$ & 0,03 & nc \\
\hline $21 / 2 / 03$ & $\mathrm{Nc}$ & 0,03 & nc \\
\hline $24 / 2 / 03$ & 2,20 & 0,03 & 1,19 \\
\hline $28 / 2 / 03$ & 2,28 & 0,02 & 1,25 \\
\hline $4 / 3 / 03$ & 2,22 & 0,02 & 1,25 \\
\hline $7 / 3 / 03$ & 2,20 & 0,02 & 1,23 \\
\hline $10 / 3 / 03$ & 2,14 & 0,01 & 1,19 \\
\hline $14 / 3 / 03$ & 2,06 & 0,03 & 1,20 \\
\hline $18 / 3 / 03$ & 1,85 & 0,02 & 1,14 \\
\hline $20 / 3 / 03$ & $\mathrm{Nc}$ & 0,02 & nc \\
\hline $21 / 3 / 03$ & nc & 0,02 & nc \\
\hline $25 / 3 / 03$ & 2,08 & 0,02 & 1,14 \\
\hline $26 / 3 / 03$ & $\mathrm{nc}$ & 0,02 & nc \\
\hline $27 / 3 / 03$ & 2,15 & 0,02 & nc \\
\hline $1 / 4 / 03$ & 2,10 & 0,02 & 1,24 \\
\hline $4 / 4 / 03$ & 2,12 & 0,02 & 1,22 \\
\hline $7 / 4 / 03$ & 2,13 & 0,02 & 1,19 \\
\hline $11 / 4 / 03$ & 2,12 & 0,02 & 1,15 \\
\hline $14 / 4 / 03$ & 2,11 & 0,02 & 1,18 \\
\hline $18 / 4 / 03$ & 2,13 & 0,02 & 1,23 \\
\hline $21 / 4 / 03$ & 2,14 & 0,02 & $\mathrm{nc}$ \\
\hline $29 / 4 / 03$ & 2,04 & 0,02 & $\mathrm{nc}$ \\
\hline $5 / 5 / 03$ & 2,03 & 0,02 & 1,08 \\
\hline $12 / 5 / 03$ & 2,08 & 0,02 & 1,26 \\
\hline $19 / 5 / 03$ & 1,99 & 0,01 & 1,09 \\
\hline Média & 2,11 & 0,02 & 1,19 \\
\hline
\end{tabular}

*nc $=$ valor não computado ou inexistente 
APÊNDICE 2 . DADOS DO MONITORAMENTO DA CONDUTIVIDADE ELÉTRICA PARA OS TRÊS TIPOS DE ÁGUAS DE IRRIGAÇÃO COM NITRATO DE CÁLCIO

\begin{tabular}{cccc}
\hline Data & $\begin{array}{c}\text { Água natural } \\
\text { com nitrato de cálcio }\end{array}$ & $\begin{array}{c}\text { Água dessalinizada } \\
\text { com nitrato de cálcio }\end{array}$ & $\begin{array}{c}\text { Água residual } \\
\text { com nitrato de cálcio }\end{array}$ \\
\hline $20 / 3 / 03$ & 2,25 & 2,97 & 3,72 \\
$24 / 3 / 03$ & 2,19 & 2,83 & 3,54 \\
$3 / 4 / 03$ & 2,17 & 2,80 & 3,70 \\
$9 / 4 / 03$ & 2,14 & 2,94 & 3,68 \\
$14 / 4 / 03$ & 2,08 & 2,81 & 3,67 \\
$24 / 4 / 03$ & 2,12 & 2,78 & 3,64 \\
$30 / 4 / 03$ & 2,02 & 2,75 & 3,74 \\
$12 / 5 / 03$ & 2,08 & 2,72 & 3,55 \\
média & $\mathbf{2 , 1 3}$ & $\mathbf{2 , 8 3}$ & $\mathbf{3 , 6 6}$ \\
\hline
\end{tabular}


APÊNDICE 3 . VOLUMES E LÂMINAS DE IRRIGAÇÃo DIÁRIOS E ACUMULADOS POR PORTA-ENXERTO DURANTE O EXPERIMENTO

\begin{tabular}{|c|c|c|c|c|c|c|}
\hline \multirow[b]{2}{*}{ DATA } & \multicolumn{2}{|c|}{ 'CLEÓPATRA' } & \multicolumn{2}{|c|}{ 'CRAVO' } & \multicolumn{2}{|c|}{ 'SWINGLE' } \\
\hline & I (mL) & I (mm) & $I(\mathrm{~mL})$ & I (mm) & $I(\mathrm{~mL})$ & I (mm) \\
\hline $10 / 3 / 2003$ & 250 & 12,43 & 250 & 12,43 & 250 & 12,43 \\
\hline $11 / 3 / 2003$ & 0 & 0,00 & 0 & 0,00 & 0 & 0,00 \\
\hline $12 / 3 / 2003$ & 130 & 6,47 & 130 & 6,47 & 130 & 6,47 \\
\hline $13 / 3 / 2003$ & 100 & 4,97 & 100 & 4,97 & 100 & 4,97 \\
\hline $14 / 3 / 2003$ & 100 & 4,97 & 100 & 4,97 & 100 & 4,97 \\
\hline $15 / 3 / 2003$ & 0 & 0,00 & 0 & 0,00 & 0 & 0,00 \\
\hline $16 / 3 / 2003$ & 0 & 0,00 & 0 & 0,00 & 0 & 0,00 \\
\hline $17 / 3 / 2003$ & 250 & 12,43 & 310 & 15,42 & 250 & 12,43 \\
\hline $18 / 3 / 2003$ & 100 & 4,97 & 130 & 6,47 & 100 & 4,97 \\
\hline $19 / 3 / 2003$ & 83 & 4,13 & 83 & 4,13 & 83 & 4,13 \\
\hline $20 / 3 / 2003$ & 83 & 4,13 & 96 & 4,77 & 83 & 4,13 \\
\hline $21 / 3 / 2003$ & 0 & 0,00 & 0 & 0,00 & 0 & 0,00 \\
\hline $22 / 3 / 2003$ & 0 & 0,00 & 0 & 0,00 & 0 & 0,00 \\
\hline $23 / 3 / 2003$ & 0 & 0,00 & 0 & 0,00 & 0 & 0,00 \\
\hline $24 / 3 / 2003$ & 250 & 12,43 & 355 & 17,66 & 275 & 13,68 \\
\hline $25 / 3 / 2003$ & 96 & 4,77 & 150 & 7,46 & 115 & 5,72 \\
\hline $26 / 3 / 2003$ & 0 & 0,00 & 0 & 0,00 & 0 & 0,00 \\
\hline $27 / 3 / 2003$ & 115 & 5,72 & 150 & 7,46 & 130 & 6,47 \\
\hline $28 / 3 / 2003$ & 0 & 0,00 & 0 & 0,00 & 0 & 0,00 \\
\hline $29 / 3 / 2003$ & 0 & 0,00 & 0 & 0,00 & 0 & 0,00 \\
\hline $30 / 3 / 2003$ & 0 & 0,00 & 0 & 0,00 & 0 & 0,00 \\
\hline $31 / 3 / 2003$ & 250 & 12,43 & 250 & 12,43 & 250 & 12,43 \\
\hline $1 / 4 / 2003$ & 83 & 4,13 & 220 & 10,94 & 83 & 4,13 \\
\hline $2 / 4 / 2003$ & 0 & 0,00 & 0 & 0,00 & 0 & 0,00 \\
\hline $3 / 4 / 2003$ & 180 & 8,95 & 270 & 13,43 & 180 & 8,95 \\
\hline $4 / 4 / 2003$ & 75 & 3,73 & 115 & 5,72 & 75 & 3,73 \\
\hline $5 / 4 / 2003$ & 0 & 0,00 & 0 & 0,00 & 0 & 0,00 \\
\hline
\end{tabular}


APÊNDICE 3 . (CONTINUAÇÃO) VOLUMES E LÂMINAS DE IRRIGAÇÃO DIÁRIOS E ACUMULADOS POR PORTA-ENXERTO DURANTE O EXPERIMENTO

\begin{tabular}{|c|c|c|c|c|c|c|}
\hline \multirow[b]{2}{*}{ DATA } & \multicolumn{2}{|c|}{ 'CLEÓPATRA' } & \multicolumn{2}{|c|}{ 'CRAVO' } & \multicolumn{2}{|c|}{ 'SWINGLE' } \\
\hline & $I(\mathbf{m L})$ & I (mm) & $I(\mathrm{~mL})$ & I (mm) & I (mL) & I (mm) \\
\hline $6 / 4 / 2003$ & 0 & 0,00 & 0 & 0,00 & 0 & 0,00 \\
\hline $7 / 4 / 2003$ & 115 & 5,72 & 190 & 9,45 & 115 & 5,72 \\
\hline $8 / 4 / 2003$ & 0 & 0,00 & 0 & 0,00 & 0 & 0,00 \\
\hline $9 / 4 / 2003$ & 130 & 6,47 & 200 & 9,95 & 130 & 6,47 \\
\hline $10 / 4 / 2003$ & 0 & 0,00 & 0 & 0,00 & 0 & 0,00 \\
\hline $11 / 4 / 2003$ & 83 & 4,13 & 150 & 7,46 & 83 & 4,13 \\
\hline $12 / 4 / 2003$ & 0 & 0,00 & 0 & 0,00 & 0 & 0,00 \\
\hline $13 / 4 / 2003$ & 0 & 0,00 & 0 & 0,00 & 0 & 0,00 \\
\hline $14 / 4 / 2003$ & 200 & 9,95 & 310 & 15,42 & 200 & 9,95 \\
\hline $15 / 4 / 2003$ & 75 & 3,73 & 150 & 7,46 & 75 & 3,73 \\
\hline $16 / 4 / 2003$ & 0 & 0,00 & 0 & 0,00 & 0 & 0,00 \\
\hline $17 / 4 / 2003$ & 115 & 5,72 & 220 & 10,94 & 115 & 5,72 \\
\hline $18 / 4 / 2003$ & 75 & 3,73 & 115 & 5,72 & 75 & 3,73 \\
\hline $19 / 4 / 2003$ & 0 & 0,00 & 0 & 0,00 & 0 & 0,00 \\
\hline $20 / 4 / 2003$ & 0 & 0,00 & 0 & 0,00 & 0 & 0,00 \\
\hline $21 / 4 / 2003$ & 0 & 0,00 & 0 & 0,00 & 0 & 0,00 \\
\hline $22 / 4 / 2003$ & 180 & 8,95 & 280 & 13,93 & 200 & 9,95 \\
\hline $23 / 4 / 2003$ & 75 & 3,73 & 250 & 12,43 & 75 & 3,73 \\
\hline $24 / 4 / 2003$ & 0 & 0,00 & 0 & 0,00 & 0 & 0,00 \\
\hline $25 / 4 / 2003$ & 150 & 7,46 & 310 & 15,42 & 150 & 7,46 \\
\hline $26 / 4 / 2003$ & 0 & 0,00 & 0 & 0,00 & 0 & 0,00 \\
\hline $27 / 4 / 2003$ & 0 & 0,00 & 0 & 0,00 & 0 & 0,00 \\
\hline $28 / 4 / 2003$ & 220 & 10,94 & 310 & 15,42 & 220 & 10,94 \\
\hline $29 / 4 / 2003$ & 0 & 0,00 & 0 & 0,00 & 0 & 0,00 \\
\hline $30 / 4 / 2003$ & 115 & 5,72 & 200 & 9,95 & 115 & 5,72 \\
\hline $1 / 5 / 2003$ & 0 & 0,00 & 0 & $.0,00$ & 0 & 0,00 \\
\hline $2 / 5 / 2003$ & 160 & 7,96 & 310 & 15,42 & 160 & 7,96 \\
\hline
\end{tabular}


APÊNDICE 3 . (CONTINUAÇÃO) VOLUMES E LÂMINAS DE IRRIGAÇÃO DIÁRIOS E ACUMULADOS POR PORTA-ENXERTO DURANTE O EXPERIMENTO

\begin{tabular}{ccccccc}
\hline & \multicolumn{2}{c}{ 'CLEÓPATRA' } & \multicolumn{2}{c}{ 'CRAVO' } & \multicolumn{2}{c}{ 'SWINGLE' } \\
DATA & $\mathbf{I}(\mathbf{m L})$ & $\mathbf{I}(\mathbf{m m})$ & $\mathbf{I}(\mathbf{m L})$ & $\mathbf{I}(\mathbf{m m})$ & I (mL) & $\mathbf{I}(\mathbf{m m})$ \\
\hline $3 / 5 / 2003$ & 0 & 0,00 & 0 & 0,00 & 0 & 0,00 \\
$4 / 5 / 2003$ & 0 & 0,00 & 0 & 0,00 & 0 & 0,00 \\
$5 / 5 / 2003$ & 180 & 8,95 & 310 & 15,42 & 150 & 7,46 \\
$6 / 5 / 2003$ & 63 & 3,13 & 83 & 4,13 & 63 & 3,13 \\
$7 / 5 / 2003$ & 0 & 0,00 & 0 & 0,00 & 0 & 0,00 \\
$8 / 5 / 2003$ & 130 & 6,47 & 250 & 12,43 & 100 & 4,97 \\
$9 / 5 / 2003$ & 63 & 3,13 & 130 & 6,47 & 63 & 3,13 \\
$10 / 5 / 2003$ & 0 & 0,00 & 0 & 0,00 & 0 & 0,00 \\
$11 / 5 / 2003$ & 0 & 0,00 & 0 & 0,00 & 0 & 0,00 \\
$12 / 5 / 2003$ & 180 & $\mathbf{8 , 9 5}$ & 310 & 15,42 & 150 & 7,46 \\
$13 / 5 / 2003$ & 0 & 0,00 & 0 & 0,00 & 0 & 0,00 \\
$14 / 5 / 2003$ & 115 & 5,72 & 180 & 8,95 & 83 & 4,13 \\
$15 / 5 / 2003$ & 0 & 0,00 & 0 & 0,00 & 0 & 0,00 \\
$16 / 5 / 2003$ & 250 & 12,43 & 250 & 12,43 & 250 & 12,43 \\
$17 / 5 / 2003$ & 0 & 0,00 & 0 & 0,00 & 0 & 0,00 \\
$18 / 5 / 2003$ & 0 & 0,00 & 0 & 0,00 & 0 & 0,00 \\
$19 / 5 / 2003$ & 160 & $\mathbf{7 , 9 6}$ & 310 & 15,42 & 120 & 5,97 \\
ACÚnMULO & $\mathbf{4 9 7 9 , 0 0}$ & $\mathbf{2 4 7 , 6 4}$ & $\mathbf{7 5 2 7 , 0 0}$ & $\mathbf{3 7 4 , 3 6}$ & $\mathbf{4 8 9 6 , 0 0}$ & $\mathbf{2 4 3 , 5 1}$ \\
MÉDIA & $\mathbf{7 0 , 1 3}$ & $\mathbf{3 , 4 9}$ & $\mathbf{1 0 6 , 0 1}$ & $\mathbf{5 , 2 7}$ & $\mathbf{6 8 , 9 6}$ & $\mathbf{3 , 4 3}$ \\
\hline
\end{tabular}


APÊNDICE 4 . TAXAS MÉdIAS ${ }^{1}$ DE LIXIVIAÇÃo POR PORTA-ENXERTO

\section{DURANTE O EXPERIMENTO}

\begin{tabular}{|c|c|c|c|c|c|c|c|c|c|}
\hline \multirow{2}{*}{$\begin{array}{l}\text { P.E. } \\
\text { Data }\end{array}$} & \multicolumn{3}{|c|}{ 'CLEÓPATRA' } & \multicolumn{3}{|c|}{ 'CRAVO' } & \multicolumn{3}{|c|}{ 'SWINGLE' } \\
\hline & $\begin{array}{c}1 \\
(\mathrm{~mL})\end{array}$ & $\begin{array}{c}\mathrm{Dr} \\
(\mathrm{mL})\end{array}$ & $\begin{array}{c}\text { Perda } \\
(\%) \\
\end{array}$ & $\begin{array}{c}I \\
(\mathrm{~mL}) \\
\end{array}$ & $\begin{array}{c}\mathrm{Dr} \\
(\mathrm{mL})\end{array}$ & $\begin{array}{c}\text { Perda } \\
(\%)\end{array}$ & $\begin{array}{c}I \\
(\mathbf{m L})\end{array}$ & $\begin{array}{c}\text { Dr } \\
(\mathbf{m L})\end{array}$ & $\begin{array}{c}\text { Perda } \\
(\%)\end{array}$ \\
\hline $12 / \mathrm{mar}$ & 250 & 133,00 & 53,20 & 250 & 130,33 & 52,13 & 250 & 145,83 & 58,33 \\
\hline $13 / \mathrm{mar}$ & 130 & 69,33 & 53,33 & 130 & 60,17 & 46,28 & 130 & 67,50 & 51,92 \\
\hline $14 /$ mar & 100 & 42,67 & 42,67 & 100 & 31,17 & 31,17 & 100 & 38,33 & 38,33 \\
\hline $17 / \mathrm{mar}$ & 100 & 28,67 & 28,67 & 100 & 19,00 & 19,00 & 100 & 22,83 & 22,83 \\
\hline $18 / \mathrm{mar}$ & 250 & 64,00 & 25,60 & 310 & 77,67 & 25,05 & 250 & 49,50 & 19,80 \\
\hline $19 /$ mar & 100 & 48,33 & 48,33 & 130 & 68,17 & 52,44 & 100 & 36,33 & 36,33 \\
\hline $20 /$ mar & 83 & 22,00 & 26,51 & 83 & 10,25 & 8,23 & 83 & 14,00 & 16,87 \\
\hline $24 / \mathrm{mar}$ & 83 & 31,67 & 38,15 & 96 & 24,33 & 25,35 & 83 & 28,17 & 33,94 \\
\hline $25 / \mathrm{mar}$ & 250 & 64,00 & 25,60 & 355 & 105,17 & 29,62 & 275 & 78,33 & 28,48 \\
\hline $26 /$ mar & 96 & 24,33 & 25,35 & 150 & 53,83 & 35,89 & 115 & 42,33 & 36,81 \\
\hline $31 / \mathrm{mar}$ & 115 & 42,00 & 36,52 & 150 & 56,00 & 37,33 & 130 & 54,33 & 41,79 \\
\hline 1/abr & 250 & $n c^{*}$ & nc & 250 & nc & nc & 250 & nc & nc \\
\hline $3 / \mathrm{abr}$ & 83 & nc & nc & 220 & nc & nc & 83 & nc & nc \\
\hline 4/abr & 180 & nc & nc & 270 & nc & nc & 180 & nc & nc \\
\hline 7/abr & 75 & nc & nc & 115 & nc & nc & 75 & nc & nc \\
\hline 8/abr & 115 & 19,33 & 16,81 & 190 & 43,00 & 22,63 & 115 & 20,67 & 17,97 \\
\hline $11 / \mathrm{abr}$ & 130 & 32,17 & 24,74 & 200 & 38,83 & 19,42 & 130 & 31,33 & 24,10 \\
\hline 14/abr & 83 & 16,50 & 19,88 & 150 & 37,50 & 25,00 & 83 & 11,33 & 6,83 \\
\hline $15 / a b r$ & 200 & 39,17 & 19,58 & 310 & 46,83 & 15,11 & 200 & 32,50 & 16,25 \\
\hline 17/abr & 75 & 24,50 & 32,67 & 150 & 60,50 & 40,33 & 75 & 23,33 & 31,11 \\
\hline $22 / a b r$ & 190 & 41,67 & 21,93 & 335 & 66,83 & 19,95 & 190 & 31,00 & 16,32 \\
\hline 23/abr & 180 & nc & nc & 280 & $\mathrm{nc}$ & nc & 200 & nc & nc \\
\hline $25 / \mathrm{abr}$ & 75 & 36,40 & 40,44 & 250 & 140,80 & 46,93 & 75 & 52,60 & 58,44 \\
\hline 28/abr & 150 & 15,75 & 7,00 & 310 & 76,25 & 16,40 & 150 & 35,40 & 19,67 \\
\hline $30 / a b r$ & 220 & $\mathrm{nc}$ & nc & 310 & nc & nc & 220 & $\mathrm{nc}$ & nc \\
\hline $2 /$ mai & 115 & 9,20 & 6,67 & 200 & 12,33 & 3,08 & 115 & 4,50 & 1,30 \\
\hline $5 / \mathrm{mai}$ & 160 & 57,33 & 35,83 & 310 & 110,17 & 35,54 & 160 & 48,00 & 30,00 \\
\hline $6 / \mathrm{mai}$ & 180 & 53,33 & 29,63 & 310 & 72,00 & 23,23 & 150 & 23,33 & 15,56 \\
\hline $8 / \mathrm{mai}$ & 63 & 20,17 & 32,01 & 83 & 3,50 & 1,41 & 63 & 17,67 & 28,04 \\
\hline 9/mai & 130 & 22,83 & 17,56 & 250 & 27,17 & 10,87 & 100 & nc & nc \\
\hline $12 /$ mai & 63 & 11,20 & 14,81 & 130 & 27,33 & 21,03 & 63 & 15,50 & 8,20 \\
\hline $13 / \mathrm{mai}$ & 180 & 47,83 & 26,57 & 310 & 53,67 & 17,31 & 150 & 27,50 & 12,22 \\
\hline
\end{tabular}


APÊNDICE 4 . (CONTINUAÇÃO)TAXAS MÉdIAS ${ }^{1}$ DE LIXIVIAÇÃO POR PORTA-ENXERTO DURANTE O EXPERIMENTO

\begin{tabular}{|c|c|c|c|c|c|c|c|c|c|}
\hline \multirow{2}{*}{$\begin{array}{l}\text { P.E. } \\
\text { Data }\end{array}$} & \multicolumn{3}{|c|}{ 'CLEÓPATRA' } & \multicolumn{3}{|c|}{ 'CRAVO' } & \multicolumn{3}{|c|}{ 'SWINGLE' } \\
\hline & $\begin{array}{c}I \\
(\mathrm{~mL})\end{array}$ & $\begin{array}{c}\mathrm{Dr} \\
(\mathrm{mL})\end{array}$ & $\begin{array}{c}\text { Perda } \\
(\%)\end{array}$ & $\begin{array}{c}I \\
(\mathbf{m L})\end{array}$ & $\begin{array}{c}\text { Dr } \\
(\mathbf{m L})\end{array}$ & $\begin{array}{c}\text { Perda } \\
(\%)\end{array}$ & $\begin{array}{c}\mathbf{I} \\
(\mathbf{m L})\end{array}$ & $\begin{array}{c}\text { Dr } \\
(\mathbf{m L})\end{array}$ & $\begin{array}{c}\text { Perda } \\
(\%)\end{array}$ \\
\hline 19/mai & 365 & 47,83 & 13,11 & 430 & 53,67 & 12,48 & 333 & 27,50 & 5,51 \\
\hline 20/mai & 160 & 51,67 & 32,29 & 310 & 41,00 & 13,23 & 120 & 33,33 & 27,78 \\
\hline Média (\%) & & & 28,41 & & & 25,23 & & & 26,10 \\
\hline
\end{tabular}

${ }^{1}$ Valores médios para 6 plantas por porta-enxerto, independente dos tratamentos

*itc = valor não computado ou inexistente 
APÊNDICE 5 - DADOS DO ACOMPANHAMENTO DA CONDUTIVIDADE ELÉTRICA DA ÁGUA DRENADA (CEdr) POR TRATAMENTO AO LONGO DO EXPERIMENTO

\begin{tabular}{cccccccccccc}
\hline Tratamento & \multicolumn{10}{c}{ CEdr } & MÉDIA \\
\cline { 2 - 9 } Data & $19 / 3$ & $19 / 3$ & $19 / 3$ & $26 / 3$ & $7 / 4$ & $17 / 4$ & $25 / 4$ & $5 / 5$ & $12 / 5$ & $19 / 5$ & \\
\hline Tr1 & 3,76 & 4,75 & 4,26 & nc* & 3,75 & 3,41 & 3,58 & 3,48 & 3,49 & 3,53 & $\mathbf{3 , 7 8}$ \\
Tr2 & 3,50 & 4,09 & 3,80 & nc & 3,92 & 4,33 & 4,68 & 5,10 & 5,20 & 5,74 & $\mathbf{4 , 4 8}$ \\
Tr3 & 2,98 & 4,06 & 3,52 & 3,93 & 3,65 & 3,94 & 4,28 & 4,70 & 4,65 & 5,00 & $\mathbf{4 , 0 7}$ \\
Tr4 & 3,19 & 3,48 & 3,34 & 3,48 & 3,52 & 4,02 & 4,32 & 4,97 & 4,80 & 5,24 & $\mathbf{4 , 0 4}$ \\
Tr5 & 3,63 & 3,63 & 3,63 & 3,82 & 4,20 & 5,49 & 5,86 & 6,06 & 6,05 & 7,27 & $\mathbf{4 , 9 6}$ \\
Tr6 & 3,86 & 4,07 & 3,97 & nc & 4,59 & 5,97 & 6,34 & 7,62 & 7,23 & 7,39 & $\mathbf{5 , 6 7}$ \\
& & & & & & & & & & & \\
Tr7 & 3,16 & 4,25 & 3,71 & 4,24 & 3,70 & 3,68 & 3,86 & 2,99 & 2,22 & 1,17 & $\mathbf{3 , 3 0}$ \\
Tr8 & 4,74 & 4,86 & 4,80 & 5,56 & 5,40 & 6,78 & 6,95 & 7,55 & 8,64 & 7,69 & $\mathbf{6 , 3 0}$ \\
Tr9 & 2,95 & 3,64 & 3,30 & 4,03 & 3,84 & 4,24 & 4,02 & 3,64 & 3,19 & 2,88 & $\mathbf{3 , 5 7}$ \\
Tr10 & 3,26 & 3,87 & 3,57 & 4,32 & 4,03 & 4,95 & 5,34 & 5,15 & 5,27 & 5,15 & $\mathbf{4 , 4 9}$ \\
Tr11 & 4,15 & 4,63 & 4,39 & 5,45 & 4,97 & 6,57 & 7,38 & 7,39 & 7,86 & 7,75 & $\mathbf{6 , 0 5}$ \\
Tr12 & 4,84 & 4,52 & 4,68 & 5,52 & 5,83 & 7,96 & 8,00 & 8,44 & 9,49 & 10,89 & $\mathbf{7 , 0 2}$ \\
& & & & & & & & & & & \\
Tr13 & 3,67 & 5,21 & 4,44 & 5,35 & 4,40 & 4,28 & 4,17 & 3,67 & 4,37 & 3,86 & $\mathbf{4 , 3 4}$ \\
Tr14 & nc & 4,40 & 4,40 & 4,46 & 4,25 & 6,00 & 5,14 & 5,99 & 6,76 & 6,76 & $\mathbf{5 , 3 5}$ \\
Tr15 & 2,97 & nc & 2,97 & 3,75 & 3,33 & 3,86 & 4,14 & 4,54 & 4,06 & 4,18 & $\mathbf{3 , 7 6}$ \\
Tr16 & 3,10 & 4,38 & 3,74 & 4,18 & 3,98 & 4,57 & 5,14 & 5,61 & 5,40 & 5,87 & $\mathbf{4 , 6 0}$ \\
Tr17 & 3,91 & 4,06 & 3,99 & 4,34 & 3,81 & 4,48 & 5,18 & 5,78 & 6,19 & 6,39 & $\mathbf{4 , 8 1}$ \\
Tr18 & 4,34 & 3,73 & 4,04 & 4,21 & 4,67 & 5,80 & 6,18 & 7,50 & 7,32 & 7,58 & $\mathbf{5 , 5 4}$ \\
\hline *nc = valor não computado ou inexistente & & & & & &
\end{tabular}


APÊNDICE 6 . VALORES MEDIDOS EM CADA PARCELA PARA OS PARÂMETROS DE AVALIAÇÃO DO DESENVOLVIMENTO DOS PORTA-ENXERTOS AOS 41 DAT E RESUMO DA ANÁLISE DE VARIÂNCIA

\begin{tabular}{ccccccc}
\hline Tratamento & Alt $(\mathrm{cm})$ & D $(\mathrm{mm})$ & MSR $(\mathrm{g})$ & MS PA $(\mathrm{g})$ & MS Total $(\mathrm{g})$ & R/PA \\
& & & & & & \\
\hline 1 & 58,90 & 4,01 & 1,33 & 3,51 & 4,84 & 0,38 \\
2 & 59,97 & 4,08 & 1,22 & 3,50 & 4,72 & 0,35 \\
3 & 59,53 & 3,99 & 1,25 & 3,23 & 4,48 & 0,39 \\
4 & 58,20 & 4,00 & 1,42 & 3,89 & 5,31 & 0,36 \\
5 & 59,63 & 3,98 & 1,22 & 3,39 & 4,60 & 0,36 \\
6 & 59,23 & 3,91 & 1,18 & 3,41 & 4,59 & 0,35 \\
& & & & & & \\
7 & 65,00 & 5,75 & 2,13 & 5,86 & 7,99 & 0,36 \\
8 & 65,97 & 5,87 & 1,96 & 5,93 & 7,89 & 0,34 \\
9 & 65,87 & 5,96 & 2,11 & 6,39 & 8,50 & 0,34 \\
10 & 64,97 & 5,64 & 2,09 & 5,63 & 7,72 & 0,37 \\
11 & 65,23 & 5,66 & 1,90 & 5,61 & 7,51 & 0,34 \\
12 & 65,40 & 5,61 & 1,90 & 5,60 & 7,49 & 0,34 \\
& & & & & & \\
13 & 60,73 & 6,39 & 1,53 & 3,80 & 5,33 & 0,42 \\
14 & 59,77 & 6,25 & 1,65 & 4,53 & 6,18 & 0,36 \\
15 & 59,57 & 6,30 & 1,61 & 4,34 & 5,95 & 0,37 \\
16 & 58,80 & 6,27 & 1,75 & 4,76 & 6,51 & 0,37 \\
17 & 59,77 & 6,25 & 1,56 & 4,27 & 5,83 & 0,36 \\
18 & 60,17 & 6,25 & 1,45 & 4,24 & 5,69 & 0,34 \\
& & & & & & \\
Ca x P.E. & 0.188 & 1.077 & 0.354 & 0.192 & 0.194 & 0.04 \\
CE x P.E. & 0.166 & 1.170 & 0.136 & 2.014 & 1.331 & 1.212
\end{tabular}

Causas da variação

Probabilidade do efeito ter se dado ao acaso ( $\mathrm{Pr}>\mathrm{F})$

\begin{tabular}{ccccccc} 
P.E. & 0.0000 & 0.0000 & 0.0000 & 0.0000 & 0.0000 & 0.0684 \\
vgCa & 0.3087 & 0.0417 & 0.0087 & 0.1815 & 0.0405 & 0.0082 \\
CE & 0.4172 & 0.0452 & 0.9250 & 0.6665 & 0.7236 & 0.6116 \\
Ca x CE & 0.5324 & 0.4754 & 0.2110 & 0.0671 & 0.0780 & 0.3640 \\
x CE. x P.E & 0.6900 & 0.1468 & 0.6697 & 0.1234 & 0.2099 & 0.8373 \\
Ca x P.E. & 0.8287 & 0.3451 & 0.7026 & 0.192 & 0.8242 & 0.9608 \\
CE x P.E. & 0.9550 & 0.3299 & 0.9684 & 0.0998 & 0.2653 & 0.3116 \\
\hline
\end{tabular}

*Significativo a $5 \%$ de probabilidade.

${ }^{15}$ Abreviaturas conforme Tabelas 8 e 13. 
APÊNDICE 7 . VALORES MEDIDOS EM CADA PARCELA PARA OS PARÂMETROS DE AVALIAÇÃO DO DESENVOLVIMENTO DOS PORTA-ENXERTOS AOS 63 DAT E RESUMO DA ANÁLISE DE VARIÂNCIA

\begin{tabular}{|c|c|c|c|c|c|c|}
\hline Tratamento & Alt (cm) & $\mathrm{D}(\mathrm{mm})$ & $\operatorname{MSR}(\mathrm{g})$ & MSPA (g) & $\operatorname{MST}(\mathrm{g})$ & R/PA \\
\hline 1 & $76, \overline{00}$ & 4,32 & 1,77 & 6,19 & 7,97 & 0,285 \\
\hline 2 & 75,50 & 4,26 & 1,66 & 6,23 & 7,89 & 0,266 \\
\hline 3 & 74,67 & 4,19 & 1,82 & 6,17 & 8,00 & 0,297 \\
\hline 4 & 72,33 & 4,09 & 1,73 & 5,70 & 7,43 & 0,305 \\
\hline 5 & 78,33 & 4,29 & 1,85 & 6,85 & 8,70 & 0,269 \\
\hline 6 & 69,67 & 3,80 & 1,54 & 5,36 & 6,90 & 0,287 \\
\hline 7 & 79,17 & 6,83 & 3,85 & 11,85 & 15,70 & 0,326 \\
\hline 8 & 81,67 & 6,31 & 3,25 & 10,89 & 14,14 & 0,297 \\
\hline 9 & 86,17 & 6,76 & 3,52 & 11,67 & 15,19 & 0,301 \\
\hline 10 & 85,83 & 6,47 & 3,30 & 11,18 & 14,48 & 0,294 \\
\hline 11 & 83,83 & 6,62 & 3,64 & 11,25 & 14,88 & 0,324 \\
\hline 12 & 85,00 & 6,27 & 3,40 & 11,44 & 14,84 & 0,298 \\
\hline 13 & 73,00 & 7,17 & 2,86 & 8,32 & 11,18 & 0,343 \\
\hline 14 & 65,83 & 6,71 & 2,49 & 7,12 & 9,61 & 0,353 \\
\hline 15 & 73,17 & 7,06 & 2,45 & 7,75 & 10,21 & 0,316 \\
\hline 16 & 65,00 & 6,59 & 2,28 & 6,68 & 8,95 & 0,348 \\
\hline 17 & 72,17 & 6,61 & 2,55 & 7,56 & 10,11 & 0,340 \\
\hline 18 & 73,33 & 6,91 & 2,70 & 7,93 & 10,63 & 0,340 \\
\hline Causas da variação & \multicolumn{6}{|c|}{ Valores de F calculados } \\
\hline P.E. ${ }^{17}$ & $45.79 *$ & $479.9^{*}$ & $147.4^{*}$ & $166.9^{*}$ & $162.7^{*}$ & $33.37 *$ \\
\hline $\mathrm{Ca}$ & 0.0029 & $5.942^{*}$ & 0.660 & 0.166 & 0.226 & 0.597 \\
\hline CE & 2.399 & $4.222^{*}$ & 1.626 & 1.499 & 1.909 & 0.285 \\
\hline $\mathrm{Ca} \times \mathrm{CE}$ & 0.474 & 1.142 & 2.548 & 1.755 & 2.108 & 1.186 \\
\hline $\mathrm{Ca} \times \mathrm{CE} \times \mathrm{P} . \mathrm{E}$ & 2.146 & 2.016 & 0.993 & 1.143 & 1.320 & 1.166 \\
\hline Ca x P.E. & 0.0214 & 0.573 & 0.362 & 0.356 & 0.209 & 2.684 \\
\hline CE $\times$ P.E. & 1.903 & 0.487 & 0.496 & 0.397 & 0.477 & 2.319 \\
\hline
\end{tabular}

Causas da variação

Probabilidade do efeito ter se dado ao acaso (Pr $>F)$

\begin{tabular}{lllllll} 
P.E. & 0.0000 & 0.0000 & 0.0000 & 0.0000 & 0.0000 & 0.0000 \\
Ca & 0.9569 & 0.0169 & 0.4190 & 0.6844 & 0.6354 & 0.4418 \\
CE & 0.0969 & 0.0179 & 0.2027 & 0.2292 & 0.1546 & 0.7527 \\
Ca x CE & 0.6243 & 0.3240 & 0.0842 & 0.1791 & 0.1278 & 0.3104 \\
CE. x P.E & 0.0821 & 0.0994 & 0.4159 & 0.3418 & 0.2690 & 0.3318 \\
Ca x P.E. & 0.9788 & 0.5661 & 0.6974 & 0.356 & 0.8120 & 0.0741 \\
CE x P.E. & 0.1173 & 0.7450 & 0.7387 & 0.397 & 0.7528 & 0.0635 \\
\hline
\end{tabular}

*Significativo a $5 \%$ de probabilidade.

${ }^{17}$ Abreviaturas conforme Tabelas 8 e 13. 
APÊNDICE 8 . VALORES MEDIDOS EM CADA PARCELA PARA OS PARÂMETROS DE AVALIAÇÃO DO DESENVOLVIMENTO DOS PORTA-ENXERTOS AOS 85 DAT E RESUMO DA ANÁLISE DE VARIÂNCIA

\begin{tabular}{cccccccc}
\hline Tratamento & ÁF $\left(\mathrm{cm}^{2}\right)$ & Alt $(\mathrm{cm})$ & D (mm) & MSR (g) & MSPA (g) & MST (g) & R/PA \\
& & & & & & & \\
\hline 1 & 665,14 & 86,50 & 4,84 & 2,29 & 8,53 & 10,82 & 0,27 \\
2 & 659,19 & 85,67 & 4,54 & 2,23 & 8,48 & 10,71 & 0,26 \\
3 & 675,78 & 86,17 & 4,53 & 2,13 & 8,60 & 10,73 & 0,24 \\
4 & 619,60 & 81,67 & 4,40 & 1,98 & 7,55 & 9,54 & 0,26 \\
5 & 590,24 & 79,83 & 4,30 & 1,96 & 7,57 & 9,53 & 0,26 \\
6 & 627,02 & 83,67 & 4,44 & 1,93 & 8,10 & 10,03 & 0,24 \\
& & & & & & & \\
7 & 1170,05 & 104,00 & 7,39 & 4,94 & 16,26 & 21,20 & 0,30 \\
8 & 1250,09 & 108,67 & 7,47 & 5,58 & 18,80 & 24,38 & 0,30 \\
9 & 1296,84 & 112,50 & 7,80 & 5,60 & 19,16 & 24,76 & 0,29 \\
10 & 1146,45 & 105,17 & 7,37 & 4,93 & 16,57 & 21,50 & 0,30 \\
11 & 1223,33 & 110,17 & 7,24 & 5,02 & 18,23 & 23,25 & 0,27 \\
12 & 1144,78 & 106,50 & 7,02 & 4,86 & 16,78 & 21,64 & 0,29 \\
& & & & & & & \\
13 & 529,26 & 76,67 & 7,96 & 3,82 & 10,74 & 14,56 & 0,36 \\
14 & 513,85 & 73,67 & 7,60 & 3,50 & 10,16 & 13,66 & 0,34 \\
15 & 544,74 & 79,00 & 7,38 & 3,43 & 10,03 & 13,47 & 0,34 \\
16 & 547,48 & 74,83 & 7,97 & 3,81 & 10,61 & 14,42 & 0,36 \\
17 & 514,51 & 73,00 & 7,72 & 3,77 & 10,66 & 14,43 & 0,35 \\
18 & 565,18 & 80,17 & 7,35 & 3,39 & 10,52 & 13,91 & 0,32
\end{tabular}

Causas da variação

P.E $E^{18}$.

$\mathrm{Ca}$

$\mathrm{CE}$

$\mathrm{Ca} \times \mathrm{CE}$

Ca $\times$ CE. $\times$ P.E

Ca $x$ P.E.

CE $x$ P.E.
$564.9 *$

0.572

0.642

2.309

0.454

0.409

2.118

Valores de $\mathrm{F}$ calculados

$\begin{array}{cccccc}244.2^{*} & 647.9^{*} & 293.5^{*} & 325.0^{*} & 334.0^{*} & 100.8^{*} \\ 0.175 & 6.837^{*} & 0.891 & 0.0582 & 0.0089 & 4.034^{*} \\ 0.836 & 2.432 & 2.104 & 1.042 & 1.281 & 2.303 \\ 2.860 & 0.192 & 0.2650 & 0.812 & 0.536 & 2.112 \\ 0.511 & 2.696^{*} & 1.504 & 1.695 & 1.739 & 1.192 \\ 0.466 & 0.0537 & 0.2680 & 0.677 & 0.600 & 0.114 \\ 2.076 & 1.094 & 0.7790 & 1.245 & 1.140 & 0.594\end{array}$

Causas da variação

P.E.

0.0000

Probabilidade do efeito ter se dado ao acaso ( $\operatorname{Pr}>\mathbf{F})$

$\mathrm{Ca}$

0.4515

0.0000

0.0000

0.0000

0.0000

0.0000

0.0000

CE

0.5288

0.6770

0.0106

0.3480

0.8100

0.9250

0.0478

$\mathrm{Ca} \times \mathrm{CE}$

0.1055

0.0628

0.0940

0.1283

0.3573

0.2830

0.1061

Ca $\times$ CE $\times$ P.E

0.7690

0.7278

0.8255

0.7680

0.4472

0.5868

0.1273

Ca $\times$ P.E.

0.6654

0.6294

0.0362

0.2082

0.1586

0.1489

0.3204

CE $\times$ P.E. 0.0855

0.0911

\begin{abstract}
0.9478
\end{abstract}
0.7659

0.5108

0.5509

0.8928

*Significativo a $5 \%$ de probabilidade.

\footnotetext{
${ }^{18}$ Abreviaturas conforme Tabelas 8 e 13.
} 